\title{
JEJAK REKAM BALAI ARKEOLOGI BANJARMASIN DALAM LAPORAN PENELITIAN ARKEOLOGI TAHUN 1993-2013
}

\section{THE TRACK RECORD OF BALAI ARKEOLOGI BANJARMASIN ON THE ARCHAEOLOGICAL RESEARCH REPORTS IN 1993-2013}

\author{
Nia Marniati Etie Fajari \\ Balai Arkeologi Banjarmasin, Jalan Gotong Royong II, RT 03/06, Banjarbaru 70711, Kalimantan Selatan; \\ email: niamarniatief@yahoo.com
}

\begin{abstract}
Abstrak. Laporan Penelitian Arkeologi yang lebih dikenal dengan istilah LPAmerupakan output kegiatan penelitian arkeologi di Balai Arkeologi Banjarmasin. Laporan disusun sebagai bentuk pertanggungjawaban baik secara administrasi dan ilmiah untuk setiap penelitian yang sudah dilakukan. Namun, fakta menunjukkan bahwa sebagian besar LPA disusun untuk sekedar memenuhi kewajiban administrasi dan cenderung mengabaikan sisi keilmiahannya. Makalah ini disusun untuk membahas kecenderungan jenis-jenis penelitian arkeologi berdasarkan LPAdi Balar Banjarmasin serta mengungkapkan permasalahan yang ada dalam penelitian dan penyusunan laporan. Kajian dilakukan dengan pengamatan parameter penelitian pada setiap jenis penelitian arkeologi yang terdiri atas eksploratif, eksplikatif atau deskriptif, dan eksplanatif. Laporan penelitian arkeologi dikelompokkan berdasarkan parameter penelitiannya, yang mencakup rumusan permasalahan dan metode penelitian (model penalaran, teknik pengumpulan data, dan metode analisis data). Hasil identifikasi tersebut kemudian diamati untuk melihat kecenderungan yang tampak pada kegiatan penelitian di Balar Banjarmasin. Kecenderungan yang dapat dilihat, yaitu sebagian besar penelitian bersifat deskriptif dengan model penalaran induktif. Kajian ini juga mengidentifikasi dua jenis masalah dalam kegiatan penelitian yang terdiri atas permasalahan akademis dan teknis. Permasalahan tersebut dirasa cukup fundamental, sehingga perlu dipikirkan solusi yang tersinergi untuk membawa penelitian arkeologi Balar Banjarmasin menuju ke arah yang lebih baik.
\end{abstract}

Kata kunci: arkeologi, penelitian, eksploratif, deskriptif, eksplanatif, Balai Arkeologi Banjarmasin

\begin{abstract}
Archaeological research reports known as LPA (Laporan Penelitian Arkeologi) are the output of archeological research activities at Balai Arkeologi Banjarmasin. The reports are compiled as the form of accountability for both administration and scientific aspects in every conducted research. The fact indicates that the most of reportswere composed as administration obligation rather than important memoir. This paper discusses the trend of archaeological research types based on the reports at Balai Arkeologi Banjarmasin and also reveals problems during the research implantation and report composing. The assessment was undertaken through research parameter observation for all kind of archaeological researches which consist of explorative, explicative or descriptive, and explanative. The reports are divided based on the content of research parameters, problem formulation and methodology (reasoning, data collecting, and analysis method). Furthermore, the resultswere observed to see the tendency in every conducted researches. The most of archaeological researches have tendency of descriptive-inductive. It is also identified the two kind of problems during research activities, academic and technical. The problems become fundamental, and need to be considered for gaining the synergies solution in order to bring archaeological researches at Balai Arkeologi Banjarmasin towards a better direction.
\end{abstract}

Keywords: archaeology, research, explorative, descriptive, explanative, Balai Arkeologi Banjarmasin

\section{PENDAHULUAN}

Balai Arkeologi Banjarmasin (selanjutnya disebut Balar Banjarmasin) adalah lembaga penelitian arkeologi di lingkungan Kementerian Pendidikan dan Kebudayaan. Balar Banjarmasin didirikan pada tahun 1993 berdasarkan Surat Keputusan (SK) Menteri Pendidikan dan Kebudayaan No. 0274/0/1993 tentang pembentukan tiga Balar, yaitu Balar Medan, Balar Banjarmasin, dan Balar Ujung Pandang. Balar Banjarmasin memiliki wilayah kerja di tiga 
provinsi, yaitu Kalimantan Selatan, Kalimantan Tengah, dan Kalimantan Timur pada awal pendiriannya. Wilayah kerja Balar Banjarmasin selanjutnya juga meliputi Provinsi Kalimantan Barat dan Kalimantan Utara'. Surat Keputusan Menteri Pendidikan dan Kebudayaan No. 33 Tahun 2013 tentang organisasi dan tata kerja Balai Arkeologi, menyebutkan tugas dan fungsi Balar, yaitu (1) pencarian benda-benda arkeologi; (2) pelaksanaan analisis dan interpretasi benda arkeologi; (3) perawatan dan pengawetan hasil benda arkeologi; (4) publikasi dan dokumentasi hasil penelitian arkeologi; (5) pelaksanaan urusan tata usaha Balar.

Sesuai dengan tugasnya, Balar Banjarmasin telah melaksanakan sejumlah penelitian arkeologi di wilayah kerjanya yang meliputi 5 provinsi, 47 kabupaten, dan 9 kota di Pulau Kalimantan. Keluaran (output) dari kegiatan penelitian ini adalah Laporan Hasil Penelitian (LPA) arkeologi sebagai bentuk pertanggungjawaban baik secara ilmiah maupun administrasi. Laporan disusun secara ilmiah untuk memaparkan latar belakang penelitian, deskripsi data, hasil analisis dan interpretasi data serta kesimpulan dan rekomendasi. Laporan penelitian umumnya disusun oleh ketua tim yang dibantu anggota dalam kelompok penelitian tersebut tanpa melalui proses telaah dan penyuntingan. Laporan penelitian arkeologi sebagai output dari kegiatan penelitian termasuk jenis karya tulis yang belum diterbitkan. Sejauh ini, sebagian besar LPA belum dievaluasi dan dikaji lebih lanjut. Laporan yang sudah dievaluasi adalah LPA yang diterbitkan dalam jurnal Berita Penelitian Arkeologi (BPA). Jurnal tersebut merupakan terbitan Balar Banjarmasin yang digunakan sebagai wadah penerbitan LPA. Laporan penelitian yang diterbitkan dalam BPA telah ditelaah oleh mitra bestari dan disunting oleh tim dewan redaksi yang ditentukan.

Permasalahan yang muncul adalah belum adanya evaluasi terhadap LPA yang tidak terbit dalam BPA. Pengalaman penulis ketika membaca sejumlah LPA di perpustakaan Balar Banjarmasin menemukan masalah yang dapat diamati secara langsung, yaitu tidak seragamnya anatomi dan format penyusunan. Selain itu, masalah mendasar yang sering terjadi adalah kurangnya konsistensi antara jenis penelitian yang dilakukan dengan perumusan masalah dan metode penelitian yang diterapkan. Tidak adanya konsistensi tersebut menyebabkan pemaparan hasil penelitian pada beberapa LPA dapat dikatakan tidak 'nyambung'. Hal tersebut disebabkan karena parameter penelitian yang dituangkan dalam LPA belum tersusun dengan baik, sehingga arah dan hasil penelitiannya cenderung membingungkan pembaca.

Kajian terhadap hasil penelitian yang tertuang dalam LPA sangat diperlukan sebagai bentuk evaluasi dan retrospeksi. Tulisan ini merumuskan beberapa hal yang menarik untuk dikaji, yaitu apa jenis penelitian arkeologi di Balar Banjarmasin dan permasalahan apa yang terdapat dalam kegiatan penelitian arkeologi? Masalah ini perlu diungkapkan sebagai bentuk evaluasi terhadap laporan penelitian arkeologi yang sudah tersusun. Evaluasi ini dapat menjadi ajang retrospeksi terhadap jejak rekam kegiatan penelitian yang dilakukan selama ini di Balar Banjarmasin. Hasil kajian terhadap LPA ini dapat menjadi dasar untuk perencanaan strategi kegiatan penelitian arkeologi yang terarah dan tersusun dengan baik. Strategi yang terarah tersebut diharapkan akan menghasilkan publikasi penelitian arkeologi yang dapat dipertanggungjawabkan secara ilmiah dan diterima oleh masyarakat luas.

Berbicara mengenai penelitian arkeologi, hal mendasar yang penting untuk dibahas adalah metode penelitian. Kata 'metode' dalam Kamus Besar Bahasa Indonesia diartikan sebagai cara kerja yang bersistem untuk memudahkan pelaksanaan suatu kegiatan guna mencapai tujuan yang ditentukan (Tim Penyusun 1995: 652). Pengertian metode penelitian arkeologi yang diajukan Tanudirdjo (1989: 10) yaitu kerangka acuan untuk menentukan ragam penelitian yang terdiri atas penalaran, sifat penelitian, pilihan strategi penelitian, dan cara perolehan data. Penentuan metode yang digunakan dipengaruhi oleh sifat dan tipe penelitian. Berdasarkan sifatnya,

Kalimantan Utara merupakan pemekaran dari Provinsi Kalimantan Timur. 
penelitian terdiri atas induktif, deduktif, dan induktifdeduktif. Menurut Mundarjito, tulisan bersifat induktif dicirikan oleh deskripsi data dengan porsi besar pada bagian awal dan diakhiri dengan kesimpulan tanpa mengungkapkan teori atau hipotesis yang melandasi pengumpulan data. Sementara itu, tulisan atau penelitian yang bersifat deduktif tahapannya diawali dengan perumusan masalah dan hipotesisnya, lalu penentuan jenis data yang relevan sebagai bukti pembenaran teori (Mundarjito 1986: 198-200).

Jenis penelitian arkeologi berdasarkan tipenya terdiri atas ekploratif, eksplikatif (deskriptif), dan eksplanatif. Penelitian eksploratif bertujuan untuk menjajagi dan mengenali data arkeologi yang belum diungkap di suatu tempat (Simanjuntak dkk. 1999: 20). Peneliti belum memiliki gambaran mengenai data arkeologi maupun kondisi lingkungan di lapangan. Pertanyaan yang dirumuskan biasanya menggunakan kata tanya 'apa' yang bertujuan untuk menggali bentuk data yang ditemukan. Penelitian eksploratif pada umumnya bersifat induktif, karena belum mendapat data banding sehingga menghasilkan kesimpulan yang bersifat menyarankan atau mendorong penelitian lanjutan (Tanudirdjo 1989: 27).

Penelitian deskriptif bertujuan untuk menggambarkan data arkeologi yang ditemukan dalam kerangka waktu, bentuk, dan ruang serta hubungan yang terjadi di antara variabel penelitian (Simanjuntak dkk. 1999: 20). Menurut Gibbon, penelitian deskriptif bertujuan untuk menyusun gambaran dan klasifikasi data arkeologi yang sistematis. Kendali metodologisnya terdiri atas pengambilan sampel, perangkat observasi, serta statistik deskriptif dan inferensia. Penelitian deskriptif umumnya menggunakan pertanyaan 'apa', 'di mana', dan 'kapan' dalam perumusan masalahnya (Gibbon 1984: 77-78). Jenis penelitian ini umum digunakan pada tahap awal penelitian atau eksplorasi data arkeologi di suatu tempat. Meskipun hal ini, seperti yang sudah diungkapkan oleh Tanudirdjo (1989: 11), menyebabkan tidak adanya batas yang benar-benar tegas antara penelitian eksploratif dengan deskriptif. Penelitian model ini bersifat induktif dan tidak memiliki pengujian hipotesis. Penelitian eksploratif dan deskriptif merupakan model penelitian yang umum dijumpai pada pemikiran arkeologi tradisional yang menganggap induktif sederhana sebagai prosedur yang sudah sesuai dan data arkeologi dipandang sebagai fenomena simpulan mengenai masa lalu (Binford 1971: 167).

Penelitian eksplanatif bertujuan untuk menjelaskan faktor yang berada di balik suatu gejala dan memberikan penjelasan dengan bertolak dari teori tertentu untuk menguji hipotesis (Simanjuntak dkk. 1999: 20). Penelitian ini menggunakan penalaran yang bersifat deduktif dan dilandasi oleh kerangka teori untuk menguji hipotesis (Tanudirdjo 1989: 28). Hipotesis diartikan sebagai penjelasan sementara yang dinyatakan sebagai dalil yang dapat diuji dengan serangkaian observasi (Sharer dan Ashmore 2003: 23).

Sharer dan Ashmore menggunakan istilah constructs, middle-range theory, dan general theory untuk menyebut tahapan penelitian, yang pada dasarnya serupa dengan eksploratif, deskriptif, dan eksplanatif. Penelitian yang bersifat construct berarti mendata dan mendefinisikan data arkeologi untuk membuat kesimpulan yang berkaitan dengan waktu, ruang, bentuk, dan fungsi. Pertanyaan umum yang diajukan pada jenis penelitian ini adalah apa bentuk data arkeologi yang menjadi tinggalan masa lalu. Terkait dengan jenis penelitian ini, pemahaman bentuk data arkeologi terdiri atas artefak, ekofak, dan fitur (Sharer dan Ashmore 2003: 25). Tahapan selanjutnya, yaitu middle-range theory yang bertujuan mencari hubungan antara aktivitas yang terjadi pada masa lalu dan sisa materialnya, di mana data arkeologi juga sebagai cerminan dari pola tingkah laku manusia. General theory pada tahap berikutnya merupakan interpretasi terhadap data arkeologi, misalnya yang terkait dengan perubahan budaya serta muncul dan berkembangnya suatu budaya (Sharer dan Ashmore 2003: 25-26).

\section{METODE}

Penelitian pada makalah ini dilakukan dengan mencermati LPA Balar Banjarmasin dari kurun 
Tabel 4. Parameter Penentuan Jenis Penelitian pada LPA

\begin{tabular}{|c|c|c|c|c|c|}
\hline $\begin{array}{c}\text { Jenis } \\
\text { Pene litian }\end{array}$ & $\begin{array}{l}\text { Bentuk Pertanyaan } \\
\text { Rumus an Masalah }\end{array}$ & Sifat & $\begin{array}{c}\text { Model } \\
\text { Penalaran }\end{array}$ & $\begin{array}{c}\text { Teknik } \\
\text { Pengumpulan Data }\end{array}$ & Analisis Da ta \\
\hline Eksploratif & apa, di mana & eksplo rasi & induktif & $\begin{array}{l}\text { studi pustaka; survei } \\
\text { arkeologi; wawan cara }\end{array}$ & analisis umum \\
\hline Deskrip tif & apa, di mana, kapan & de skripsi & $\begin{array}{l}\text { induktif; } \\
\text { induktif- } \\
\text { dedu ktif }\end{array}$ & $\begin{array}{l}\text { studi pustaka; survei } \\
\text { ekskavasi arkeologi; } \\
\text { wawan cara }\end{array}$ & analisis umum \\
\hline Eksplanatif & $\begin{array}{l}\text { bagaimana, mengapa, } \\
\text { siapa }\end{array}$ & eksplanasi & deduktif & $\begin{array}{ll}\text { studi pustaka; su rvei- } & \text { arkeologi; } \\
\text { ekska vasi } & \text { wawan cara }\end{array}$ & $\begin{array}{l}\text { analisis } \\
\text { khusus }\end{array}$ \\
\hline
\end{tabular}

waktu 1993-2013 (lihat lampiran: tabel 1, 2, dan 3). Setiap LPA dianalisis secara kualitatif dan kuantitatif untuk menjawab permasalahan yang sudah dirumuskan. Analisis kualitatif dilakukan dengan mengklasifikasikan LPA berdasarkan sifat penelitian, yaitu eksploratif, deskriptif, dan eksplanatif. Instrumen yang digunakan untuk penentuan sifat penelitian tersebut adalah rumusan permasalahan serta penentuan metode penelitian yang terdiri atas model penalaran, cara pengumpulan data, dan jenis analisis data serta kesimpulan. Pengamatan pada kesimpulan dilakukan dengan melihat kerunutan pola pikir dalam penyusunan laporan. Kerangka acuan yang digunakan sebagai parameter untuk menentukan jenis penelitian disusun dalam tabel 4 .

Aspek pengamatan tersebut diharapkan dapat memberikan ulasan mengenai LPA Balar Banjarmasin sebagai bentuk evaluasi dan retrospeksi terhadap pelaksanaan kegiatan penelitian selama ini. Analisis kuantitatif dilakukan dengan membuat tabulasi LPA yang sudah dikelompokkan berdasarkan kategori tertentu, antara lain tema penelitian, jenis pertanyaan pada permasalahan, sifat penelitian, dan teknik pengumpulan data. Hasil dari tabulasi ini memberikan gambaran mengenai kecenderungan pola penelitian arkeologi di Balar Banjarmasin.

\section{HASIL DAN PEMBAHASAN}

\section{Kajian Kegiatan Penelitian Arkeologi}

Kajian mengenai jenis penelitian sebelumnya pernah dibahas oleh Daud Aris Tanudirdjo (1989) dalam karya yang berjudul Ragam Metoda
Penelitian Arkeologi dalam Skripsi Karya Mahasiswa Arkeologi Universitas Gadjah Mada. Pada kajian tersebut, Tanudirdjo membahas sejumlah skripsi mahasiswa sebagai bentuk evaluasi normatif dengan melihat dan meneliti pelaksanaan program terkait ragam penelitian skripsi yang bertujuan untuk memperbaikinya ketika program tersebut dirasa kurang berhasil. Berdasarkan kerangka acuan yang sudah disusun, kesimpulan yang diperoleh yaitu: (1) penelitian pada umumnya menggunakan penalaran induktif dengan pilihan strategi interpretasi-teoritis, yang menunjukkan bahwa arkeologi Indonesia masih terpaku pada pola lama berdasarkan paradigma sejarah budaya; (2) adanya kerancuan dan kekurangpahaman mengenai proses bernalar yang menyebabkan kendala dalam memilih ragam penelitian yang tepat; (3) metode arkeologi belum diterapkan dengan sebaik-baiknya sehingga memerlukan perhatian khusus dari para pakar arkeologi di Indonesia (Tanudirdjo 1989: 52-56).

Pembahasan mengenai LPA Balar Banjarmasin dilakukan oleh Wasita (2014: 105126), yang mengungkapkan bahwa penelitianpenelitian arkeologi di Balar Banjarmasin sebagian besar belum final. Pengamatan tersebut dilakukan terhadap 132 LPA yang berasal dari tahun 1993-2013. Pengertian penelitian yang belum final yaitu laporan yang pemaparannya berupa data, potensi suatu situs arkeologi, serta rekomendasi untuk penelitian lanjutan. Sementara itu, penelitian yang dianggap sudah final yaitu yang menggambarkan dan/atau menjelaskan data arkeologi secara menyeluruh. Permasalahan mengenai penelitian yang belum final tersebut menurut Wasita tidak menunjukkan adanya 
permasalahan yang serius. Meskipun demikian, Wasita menyarankan suatu kegiatan penelitian arkeologi yang implementatif sehingga dapat lebih bermanfaat (Wasita, 2014: 113). Berseberangan dengan pernyataan Wasita sebelumnya, penulis berpendapat, banyaknya penelitian yang belum final sebenarnya merupakan masalah serius yang perlu dipikirkan. Penelitian yang sudah dianggap final pun implikasinya terhadap perkembangan arkeologi Kalimantan belum dapat dirasakan secara nyata. Laporan-laporan penelitian arkeologi saat ini masih terkesan terpisah-pisah sehingga belum dapat menjalin interpretasi yang menyeluruh mengenai arkeologi Kalimantan.

Sementara itu, Imam Hindarto (2013: 1-13) dalam artikelnya membahas mengenai kecenderungan proposal penelitian Balar Banjarmasin yang diajukan selama tahun anggaran 2009-2012. Hasil kajian terhadap 38 proposal menunjukkan adanya kecenderungan penelitian yang mengarah pada paradigma sejarah budaya. Kajian ini juga berhasil mengidentifikasi masalah dalam proposal yang diajukan, yaitu (1) data yang tidak dapat terintegrasi dengan baik sehingga menyebabkan interpretasi mengenai arkeologi Kalimantan belum dapat disusun; (2) metode penelitian yang digunakan kurang tepat; (3) kurangnya kajian atas teori yang menyebabkan orientasi penelitian terasa samar. Selain itu, Hindarto juga menuliskan gagasan tema payung dalam penelitian arkeologi di Kalimantan sebagai dasar untuk menentukan arah penelitian yang sesuai dengan visi dan misi Balar Banjarmasin (Hindarto 2013: 8). Sejalan dengan pemikiran tersebut, kajian terhadap LPA sendiri sangat penting untuk dilakukan. Seperti yang disebutkan oleh Edi Sedyawati (2001: 3-4) bahwa tolok ukur keberhasilan lembaga penelitian terletak pada kualitas dan kuantitas penelitian, serta taraf kedisiplinan para peneliti dalam menalar dan bekerja sesuai dengan disiplin keilmuan. Pemikiran tersebut dapat menjadi dasar agar Balar Banjarmasin sebagai lembaga penelitian arkeologi dapat selalu dijaga sehingga tidak cenderung terjebak dalam anggapan bahwa LPA adalah bagian dari rutinitas, serta menjadi instansi yang kurang peka pada kualitas dan ketajaman laporan.
Jejak Rekam Penelitian Balar Banjarmasin dalam LPA

Data yang dikaji adalah LPA Balar Banjarmasin tahun 1993-2013 (lihat tabel 1, 2, dan 3 pada lampiran) yang terdapat dalam katalog koleksi perpustakaan. Proses pengumpulan data sendiri bukanlah tanpa kendala, karena dari seluruh judul LPA yang ada tidak semuanya dapat ditemukan pada saat penelitian berlangsung. Hal tersebut disebabkan oleh beberapa hal, yaitu LPA penelitian yang tidak selesai, LPA yang dipinjam dan belum dikembalikan ke perpustakaan pada saat penelitian berlangsung, dan LPA yang sudah selesai tetapi belum diserahkan kepada perpustakaan. Khusus untuk penelitian yang belum selesai dan tidak ditemukan dalam daftar katalog perpustakaan, LPA tidak dijadikan sebagai bahan kajian. Laporan penelitian arkeologi dikelompokkan dalam tujuh kategori berdasarkan tema penelitian, yaitu penelitian survei eksplorasi, arkeologi prasejarah, arkeologi Hindu-Buddha, arkeologi Islam, arkeologi Kolonial, arkeologi pemukiman/lingkungan, dan penelitian etnoarkeologi/etnografi (lihat tabel 5).

Penelitian arkeologi prasejarah yang dilakukan di Balar Banjarmasin berkaitan dengan hunian manusia prasejarah di gua-gua kapur maupun di situs terbuka (open sites) di tepi sungai. Wilayah yang menjadi favorit adalah Kalimantan Selatan yang mendominasi jumlah penelitian (gambar 1). Situs-situs prasejarah sebagian besar ditemukan pada gugusan bukit kapur, di antaranya berada di karst Batubuli (Tabalong), karst Telaga Langsat (Hulu Sungai Selatan), dan karst Mantewe (Tanah Bumbu) di Kalimantan Selatan, serta kawasan karst Sangkulirang-Mangkalihat di Kalimantan Timur. Wilayah yang sudah diteliti secara intensif yaitu Gunung Batubuli dan

Tabel 5. Jumlah LPA Balar Banjarmasin berdasarkan Tema Penelitian

\begin{tabular}{|l|r|r|}
\hline \multicolumn{1}{|c|}{ Tem a Penelitian } & \multicolumn{1}{c|}{ Jumlah } & \multicolumn{1}{c|}{$\%$} \\
\hline Survei Eksplorasi & 22 & 16.67 \\
\hline Arkeologi Prasejarah & 15 & 12.12 \\
\hline Arkeologi Hindu-Buddha & 21 & 15.91 \\
\hline Arkeologi Is lam & 13 & 9.85 \\
\hline Arkeologi Kolonial & 15 & 11.36 \\
\hline Arkeologi Pemukiman/Lin gkungan & 16 & 11.36 \\
\hline Etn oarkeologi & 30 & 22.73 \\
\hline
\end{tabular}


Mantewe. Hunian manusia prasejarah di Batubuli ditemukan di Gua Babi dan Gua Tengkorak, yang memiliki kronologi waktu sejak 6000 tahun yang lalu (Widianto dan Handini 2003: 72). Temuan prasejarah di Mantewe didapatkan di sejumlah gua, yaitu Gua Bangkai dan Gua Payung (Sugiyanto 2008: 1-27; Fajari dan Kusmartono 2013: 20-23).

Pada awal-awal penelitian arkeologi HinduBuddha di Balar Banjarmasin, situs yang banyak mendapatkan perhatian adalah Candi Agung dan kompleks Candi Laras-Pematang Bata di Kalimantan Selatan, serta situs Muara Kaman dan sekitarnya di Kalimantan Timur. Hal tersebut disebabkan karena data arkeologi dari masa Hindu-Buddha belum banyak ditemukan pada awal masa operasional Balar Banjarmasin. Wilayah lain yang mulai menarik perhatian akhirakhir ini adalah daerah aliran sungai di Kalimantan Barat, dengan sejumlah temuan yang memiliki karakteristik budaya Hindu-Buddha. Sementara itu, data arkeologi dari masa Hindu-Buddha di wilayah Kalimantan Tengah belum banyak terungkap.

Tema arkeologi Islam-Kolonial umumnya membahas permasalahan yang berkaitan dengan perkembangan budaya pengaruh Islam dan Kolonial Belanda. Tema yang umum dikemukakan adalah arsitektur makam, identifikasi naskah kuno, dan perkembangan tata kota. Wilayah yang diteliti hampir merata di kelima provinsi di Pulau Kalimantan. Tema penelitian arkeologi pemukiman/lingkungan umumnya berkaitan dengan jejak-jejak hunian kuna di daerah aliran sungai, baik yang sudah mati ataupun yang masih mengalir hingga saat ini. Kronologi situssitus yang diteliti bervariasi mulai dari masa prasejarah sampai dengan masa saat ini. Sementara itu, tema penelitian etnoarkeologi memiliki jumlah LPA yang paling banyak di antara tema yang lainnya. Topik yang banyak diangkat pada penelitian etnoarkeologi di Balar Banjarmasin antara lain adalah konsep kematian dalam religi masyarakat Dayak, variasi bangunan kubur dan tata cara prosesi penguburan, teknologi, serta bahasa.

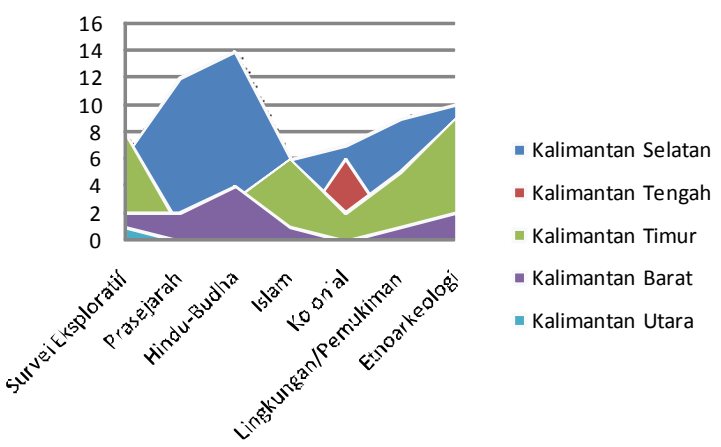

Gambar 1. Distribusi tema penelitian di wilayah kerja Balar Banjarmasin.

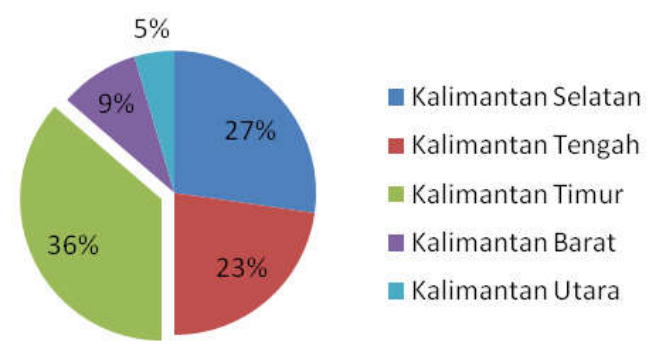

Gambar 2. Distribusi penelitian eksploratif di wilayah kerja Balar Banjarmasin.

\section{Klasifikasi LPA Berdasarkan Tema Penelitian}

Dasar klasifikasi yang dilakukan untuk menentukan jenis penelitian adalah sifat penelitian yang ditetapkan dalam setiap LPA. Sifat penelitian arkeologi terdiri atas tiga jenis, yaitu eksplorasi, eksplikasi atau deskripsi, dan eksplanasi. Deskripsi dari masing-masing sifat penelitian telah dijabarkan pada bagian tinjauan pustaka. Identifikasi jenis penelitian berdasarkan sifat ini dilakukan dengan mengamati parameter sesuai dengan kerangka yang sudah ditentukan sebelumnya. Berdasarkan kerangka tersebut, jenis penelitian pada LPABalar Banjarmasin terdiri atas penelitian eksploratif dan penelitian deskriptif, serta penelitian yang memiliki kecenderungan ekplanatif.

Penelitian Eksploratif

Eksplorasi atau penjajagan merupakan tahapan paling awal dalam penelitian arkeologi. Penelitian eksploratif memiliki ciri umum yang dapat dilihat dari permasalahan, tujuan, sasaran, 
dan metode pengumpulan data di lapangan. Permasalahan yang seringkali diajukan adalah bentuk dan sebaran data arkeologi di suatu lokasi atau situs, dengan tujuan penelitiannya untuk menjawab masalah yang telah dirumuskan. Sasaran penelitian yang dicari adalah semua data arkeologi yang ditemukan selama proses penelitian. Distribusi wilayah penelitian eksploratif ini tidak merata di setiap provinsi (lihat gambar 2).

Jenis penelitian eksploratif LPA Balar Banjarmasin umumnya mudah ditentukan karena kata 'eksploratif' atau 'eksplorasi' hampir selalu dicantumkan pada judul. Meskipun demikian, hasil pengamatan menunjukkan bahwa tidak semua penelitian yang menyebut kata tersebut pada bagian judulnya dapat dikatakan sebagai penelitian eksploratif. Berdasarkan parameter pengamatan, penelitian eksploratif di Balar Banjarmasin terdiri atas 29 LPA. Parameter pertama yang diamati adalah bentuk pertanyaan pada perumusan masalah, yang umumnya terdiri atas kata tanya 'apa' dan di mana'. Jenis kata tanya lain yang digunakan pada umumnya cenderung menuntun penelitian eksploratif menjadi pemaparan yang bersifat deskriptif. Rincian jenis pertanyaan yang digunakan pada LPA Balar Banjarmasin dapat dilihat pada tabel 6 .

Tabel 6. Identifikasi Jenis Pertanyaan pada Penelitian Eksploratif

\begin{tabular}{|c|c|c|}
\hline Pertanyaan & Jumlah & $\%$ \\
\hline apa & 15 & $51.72 \%$ \\
\hline apa-bagaimana & 7 & $24.14 \%$ \\
\hline bagaimana & 5 & $17.24 \%$ \\
\hline tidak disebutkan & 2 & $6.90 \%$ \\
\hline
\end{tabular}

Tabel 7. Identifikasi Penelitian Eksploratif

\begin{tabular}{|c|c|c|}
\hline Sifat Penelitian & Jumlah & $\%$ \\
\hline eks plorasi & 11 & $31 \%$ \\
\hline eksplorasi-deskripsi & 5 & $38 \%$ \\
\hline deskripsi & 4 & $17 \%$ \\
\hline tidak disebutkan & 9 & $14 \%$ \\
\hline
\end{tabular}

Pertanyaan 'apa' merupakan jenis pertanyaan yang paling banyak digunakan. Permasalahan yang diajukan umumnya terkait dengan potensi arkeologi dan bentuk data arkeologi yang ditemukan pada saat penelitian. Jenis pertanyaan ini memang tepat digunakan, mengingat penelitian yang bersifat eksplorasi sebatas penjajagan pada jenis data apa saja yang ditemukan di lapangan. Pertanyaan 'bagaimana' yang muncul sebagai tambahan dari rumusan permasalahan, umumnya berkaitan dengan penjelasan lebih lanjut tentang data arkeologi yang ditemukan. Misalnya, pada LPA Survei Eksploratif Arkeologi di Provinsi Kalimantan Tengah tahun 1995 (rincian lebih lanjut bisa dilihat pada lampiran), yang merumuskan pertanyaan tentang apa potensi arkeologi dan bagaimana aktivitas pemukiman kuno di lokasi penelitian (Wibisono dan Kusmartono 1995: 3). Perumusan pertanyaan 'bagaimana' di sini menjadi tidak tepat untuk digunakan karena penelitian menjadi bersifat lebih ke arah deskripsi daripada eksplorasi. Ketidaktepatan tersebut juga tampak pada penentuan sifat penelitian yang dicantumkan, yaitu deskripsi-induktif. Padahal dari judul, jelas dicantumkan bahwa jenis penelitian termasuk eksploratif. Memang pada kenyataannya, kadang terdapat tumpang-tindih antara penelitian eksploratif dan deskriptif. Penentuan rumusan permasalahan yang tepat setidaknya dapat digunakan untuk memberi batasan antara kedua penelitian tersebut.

Selanjutnya, pengamatan berdasarkan sifat penelitian dapat dilihat pada tabel 7 , yang memperlihatkan adanya tumpang-tindih antara penelitian eksploratif dan deskriptif. Tabel 7 menunjukkan empat LPA yang menyebutkan sifat penelitiannya adalah deskripsi, sedangkan 5 LPA menggunakan gabungan dari eksplorasi dan deskripsi. Penentuan sifat deskripsi pada keempat LPA tersebut menjadi tidak tepat ketika seluruhnya jelas menyebutkan jenis penelitian eksploratif pada bagian judul². Sementara itu, gabungan antara eksplorasi-deskripsi bisa

Survei Eksploratif Arkeologi di Provinsi Kalimantan Tengah (1995); Survei Gua-gua di Pegunungan Muller Kecamatan Sangkulirang, Kabupaten Kutai, Kalimantan Timur (1995); Survei Eksploratif Arkeologi di Kalimantan Timur (1996); Survei Eksploratif DAS Barito Tahap I, Kabupaten Barito Utara, Kalimantan Tengah (1998). 
dilakukan ketika penelitian arkeologi dilakukan tidak hanya untuk penjagagan saja, tetapi bertujuan untuk memaparkan mengenai data arkeologi yang ditemukan.

Pengamatan terhadap model penalaran, 19 LPA (66\%) menggunakan penalaran induktif dan 10 lainnya (34\%) tidak disebutkan. Pemilihan penalaran induktif pada penelitian eksploratif tepat digunakan mengingat pada tataran ini belum ada data lain yang dapat dijadikan pembanding. Sementara itu, pengamatan cara pengumpulan data menunjukkan bahwa survei dan wawancara menjadi pilihan paling banyak dilakukan (lihat tabel 8). Pengumpulan data melalui studi pustaka hanya terdapat pada 7 LPA, sedangkan ekskavasi terdapat pada 4 LPA. Kecenderungan pemilihan cara pengumpulan data melalui survei sejalan dengan tujuan dari penelitian eksploratif sendiri, yaitu penjajagan potensi arkeologi di lapangan. Ekskavasi dirasa belum diperlukan secara signifikan pada tataran ini. Meskipun demikian, apabila diperlukan, pengumpulan data dengan ekskavasi, dapat dilakukan dengan membuka lubang uji untuk memastikan potensi arkeologi di lokasi tertentu.

Tahapan selanjutnya, setelah data terkumpul tentunya adalah analisis data. Pengamatan terhadap metode analisis data yang dilakukan menunjukkan adanya kecenderungan, bahwa tahapan ini belum banyak diperhatikan dalam penyusunan LPA. Dari 29 LPA yang ada, hanya dua buah $(7 \%)$ yang menyebutkan pilihan analisis data $^{3}$. Sementara $93 \%$ sisanya tidak dapat diketahui jenis analisis yang digunakan. Identifikasi jenis analisis yang digunakan pada pemaparan data cenderung sulit dilakukan, karena pembahasan umumnya menuliskan mengenai gambaran umum tanpa menyebutkan proses analisisnya.

\section{Penelitian Deskriptif}

Penelitian deskriptif dilakukan untuk mengetahui gambaran mengenai data arkeologi dalam bentuk, ruang, dan waktu, yang bertujuan untuk mengungkapkan hubungan antarvariabel
Tabel 8. Teknik Pengumpulan Data pada Penelitian Eksploratif

\begin{tabular}{|l|c|c|}
\hline \multicolumn{1}{|c|}{ Teknik Pengumpulan Data } & Jumlah & $\%$ \\
\hline survei & 8 & $27.59 \%$ \\
\hline survei-studi-pustaka & 3 & $10.34 \%$ \\
\hline survei-studi pustaka-wawancara & 4 & $13.79 \%$ \\
\hline survei-wawancara & 10 & $34.48 \%$ \\
\hline ekskavasi & 1 & $3.45 \%$ \\
\hline survei-ekskavasi-wawancara & 1 & $3.45 \%$ \\
\hline survei-ekskavasi & 2 & $6.90 \%$ \\
\hline
\end{tabular}

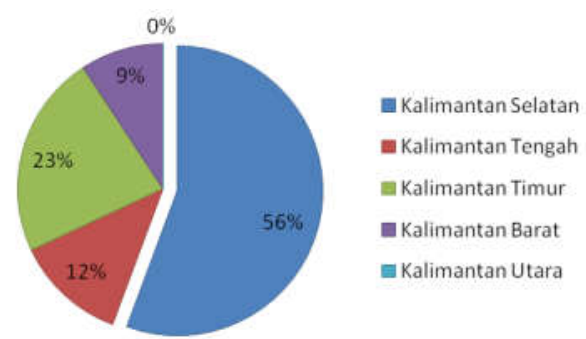

Gambar 3. Distribusi penelitian deskriptif di wilayah kerja Balar Banjarmasin.

(Tanudirdjo 1993: 77). Tidak seperti jenis penelitian eksploratif yang dapat diamati dari judul, penentuan jenis penelitian ini harus dilakukan dengan pengamatan pada parameter yang sudah ditentukan. Berdasarkan pengamatan, kelompok penelitian deskriptif di Balar Banjarmasin total berjumlah 97 penelitian. Distribusi pelaksanaan penelitian di wilayah kerja tidak merata di seluruh provinsi. Penelitian deskriptif paling banyak dilakukan pada situs arkeologi yang berada di Provinsi Kalimantan Selatan (gambar 3). Sementara itu, Provinsi Kalimantan Utara sama sekali belum mendapat porsi penelitian deskriptif, mengingat provinsi tersebut baru terbentuk pada tahun 2013.

Bentuk pertanyaan dalam perumusan masalah pada kelompok penelitian deskriptif yang ditemukan merupakan paduan dari beberapa kata tanya, di antaranya adalah 'apabagaimana'; 'apa-di mana-bagaimana' atau 'apasiapa'. Rincian dari jenis pertanyaan yang diajukan dapat dilihat pada tabel 9. Pertanyaan 'apa-bagaimana' merupakan pilihan yang paling banyak digunakan dalam penelitian. Pertanyaan

3 Penelitian Eksplorasi Arkeologi di Kepulauan Maya Karimata, Kalimantan Barat (2010) dan Penelitian Arkeologi DAS Kapuas Bagian Hulu, Kabupaten Kapuas Hulu, Kalimantan Barat (2013). 
tersebut pada umumnya digunakan untuk mengetahui bentuk data arkeologi dan penjelasan-penjelasan yang dapat diungkapkan dari data yang ditemukan. Sementara itu, pertanyaan 'kapan' yang muncul pada 9 buah LPA menunjukkan adanya upaya untuk mengungkapkan kronologi waktu dari data arkeologi yang ditemukan ${ }^{4}$. Masalah kronologi waktu dalam penelitian arkeologi sekiranya penting untuk selalu diungkapkan. Penentuan pertanggalan suatu situs atau data arkeologi dapat digunakan sebagai dasar untuk menyusun kerangka waktu dalam perkembangan budaya dari masa ke masa. Oleh karena itu, pertanyaan 'kapan' sudah selayaknya dapat dimasukkan dalam perumusan masalah pada setiap penelitian deskriptif yang dilakukan.

Pada parameter sifat penelitian, sebanyak 50 LPA dengan tegas dapat dikelompokkan sebagai penelitian deskriptif, dan 5 LPA yang memilih gabungan sifat antara eksplorasi-deskripsi (lihat tabel 10). Pengamatan juga menemukan 6 penelitian yang menggunakan sifat deskripsikomparasi. Sementara itu, sebanyak 36 LPA tidak menyebutkan sifat penelitian dalam penyusunannya. Model penalaran induktif menjadi pilihan favorit yang digunakan. Penelitian dengan penalaran induktif ditemukan pada 65 LPA, sedangkan 35 LPA lainnya tidak menyebutkan jenis penalaran yang digunakan.

Survei, ekskavasi, dan wawancara merupakan cara pengumpulan data yang dilakukan pada sebagian besar penelitian deskriptif di Balar Banjarmasin (tabel 11). Jumlah total metode survei dilakukan pada 76 LPA,
Tabel 9. Identifikasi Jenis Pertanyaan pada Penelitian Deskriptif

\begin{tabular}{|l|r|r|}
\hline \multicolumn{1}{|c|}{ Jenis Pertanyaan } & \multicolumn{1}{c|}{ Jumlah } & \multicolumn{1}{c|}{$\%$} \\
\hline apa-bagaimana & 21 & 21.65 \\
\hline apa & 12 & 12.37 \\
\hline siapa-bagaimana & 2 & 2.06 \\
\hline apa-kapan-bagaimana & 2 & 2.06 \\
\hline apa-di mana-bagaimana & 1 & 1.03 \\
\hline apa-kapan & 2 & 2.06 \\
\hline kapan & 3 & 3.09 \\
\hline kapan-bagaimana & 1 & 1.03 \\
\hline bagaimana-mengapa & 1 & 1.03 \\
\hline apa-siapa & 1 & 1.03 \\
\hline apa-siapa-bagaimana & 1 & 1.03 \\
\hline di mana & 1 & 1.03 \\
\hline apa-kapan-siapa & 1 & 1.03 \\
\hline bagaimana-siapa & 1 & 1.03 \\
\hline di mana-bagaimana & 1 & 1.03 \\
\hline bagaimana & 21 & 21.65 \\
\hline apa-di mana & 1 & 1.03 \\
\hline tidak disebutkan & 24 & $24.74 \%$ \\
\hline
\end{tabular}

Tabel 10. Identifikasi Sifat Penelitian Deskriptif

\begin{tabular}{|l|r|r|}
\hline \multicolumn{1}{|c|}{ Sifat Penel itian } & Jumlah & \multicolumn{1}{c|}{$\%$} \\
\hline eks plorasi-des kripsi & 5 & 5.15 \\
\hline deskripsi & 50 & 51.55 \\
\hline deskripsi-komparasi & 6 & 6.19 \\
\hline tidak disebutkan & 36 & 37.11 \\
\hline
\end{tabular}

ekskavasi pada 46 LPA, dan wawancara pada 45 LPA . Sementara itu, pengumpulan data melalui studi pustaka sangat jarang dilakukan (8 LPA). Selanjutnya, pengamatan terhadap analisis data ditemukan sebanyak 56 LPA (58\%) mencantumkan sejumlah pilihan analisis data, di antaranya adalah analisis artefaktual, analisis kontekstual, dan analisis khusus sesuai dengan rumusan permasalan pada penelitian. Sebanyak 41 LPA lainnya (42\%) tidak mencantumkan model analisis data yang digunakan.

$4 \quad$ Penelitian Situs Candi Laras Tahap III, Kabupaten Tapin, Kalimantan Selatan (1998); Penelitian Situs Candi Laras Tahap IV, Kabupaten Tapin, Kalimantan Selatan (1999); Pertanggalan Radiokarbon Situs Pematang Bata, Candi Laras, Kabupaten Tapin, Kalimantan Selatan (1999); Pertanggalan Radiokarbon Situs Candi Laras, Kabupaten Tapin, Kalimantan Selatan (2000); Umur Candi Laras dalam Panggung Sejarah Kuna Indonesia (2000); Situs Masjid Keramat Banua Halat, Kabupaten Tapin (2006); Pemukiman Prasejarah Situs Jambu Hilir, Kecamatan Kandangan, Kabupaten Hulu Sungai Selatan, Provinsi Kalimantan Selatan (2007); Kubur Tajau Sanga Sanga Kabupaten Kutai Kertanegara, Kalimantan Timur (2010); Penelitian Arkeologi Situs Pulau Jangkung Kabupaten Tabalong, Kalimantan Selatan (2012).

5 Tata Cara Prosesi Penguburan dan Upacara ljambe di Kecamatan Dusun Timur, Kabupaten Barito Timur, Kalimantan Tengah(2003); Penelitian Arsitektur Rumah Adat Lamin di Kecamatan Jempang, Kabupaten Kutai Barat Kalimantan Timur(2004); Ekskavasi Candi Agung Tahun 2005 (2005); Penelitian Sistem Penguburan Pada Masyarakat Dayak Lawangan di Barito Setatan(2005); Ekskavasi Candi Agung Tahun 2006 (2006); Penelitian Arkeologi Urban Bekas Kerajaan Paser di Kota Tanah Grogot Kabupaten Paser Provinsi Kalimantan Selatan (2011). 
Tabel 11. Teknik Pengumpulan Data pada Penelitian Deskriptif

\begin{tabular}{|l|r|r|}
\hline \multicolumn{1}{|c|}{ Pengumpulan Data } & Jumlah & \multicolumn{1}{c|}{$\%$} \\
\hline survei-ekskavasi & 26 & 26.80 \\
\hline survei-studi pustaka & 3 & 3.09 \\
\hline ekskavasi & 13 & 13.40 \\
\hline survei-ekskavasi-wawancara & 4 & 4.12 \\
\hline survei-wawancara & 29 & 29.90 \\
\hline wawancara & 2 & 2.06 \\
\hline survei-studi pustaka-wawancara & 4 & 4.12 \\
\hline studi pustaka-wawancara & 1 & 1.03 \\
\hline lain-lain & 3 & 3.09 \\
\hline survei & 6 & 6.19 \\
\hline tidak disebutkan & 6 & 6.19 \\
\hline
\end{tabular}

\section{Penelitian Eksplanatif}

Pengamatan terhadap sifat penelitian ditemukan 6 buah LPA yang memiliki kecenderungan sebagai penelitian eksplanatif5. Kelima LPA tersebut menggunakan deskripsieksplanasi sebagai sifat penelitiannya. Bentuk pertanyaan yang diajukan adalah apa, bagaimana, siapa, dan di mana. Dua LPA memiliki tema yang serupa, yaitu sistem penguburan pada masyarakat Dayak di Kalimantan Tengah. Penelitian ini mengajukan permasalahan untuk menjelaskan tata cara penguburan yang terkait dengan konsep religi tradisional masyarakat Dayak di daerah Barito Selatan dan Timur, serta bentuk kesinambungan budaya yang ada dengan religi yang berkembang pada masa prasejarah (Wasita dan Sunarningsih 2003: 5; Wasita 2005: 4). Dua LPA lainnya berusaha untuk menjelaskan mengenai kemungkinan letak lokasi hunian masa lalu di Situs Candi Agung. Kedua penelitian tersebut berhasil menemukan sejumlah data yang menunjukkan sisa aktivitas pada masa lalu, tetapi gambaran lengkap mengenai karakter pemukiman kuno di Candi Agung sampai saat ini belum terpecahkan. Satu penelitian yang lainnya tidak banyak yang dapat diungkap karena tidak menyebutkan rumusan masalah, pengumpulan data, dan model analisis yang digunakan.

Kelima LPA tersebut memang dapat diklasifikasikan sebagai penelitian eksplanatif, karena sifat penelitian berusaha memberikan penjelasan mengenai permasalahan secara mendalam. Penelitian eksplanatif memang seharusnya memberikan penjelasan mengenai 'mengapa' dan 'bagaimana' terkait dengan gejala yang diteliti dengan menerapkan dalil, model, atau teori tertentu (Tanudirdjo 1993: 77). Hal yang kurang tepat di sini adalah lima LPA pada kelompok ini cenderung memilih menggunakan model penalaran induktif daripada deduktif, seperti yang seharusnya dilaksanakan pada penelitian eksplanatif. Hanya satu LPA yang hipotesis seperti yang sudah seharusnya ada dalam sebuah penelitian eksplanatif. Tidak dipilinnya model penalaran deduktif menyebabkan tidak satu pun dari kelimanya mengajukan hipotesis untuk diuji dalam proses penelitian.

\section{Kecenderungan Penelitian Balar Banjarmasin}

Hasil klasifikasi jenis penelitian berdasarkan data yang ditemukan pada LPA menunjukkan, model penelitian deskriptif merupakan tipe yang dominan dilakukan dalam kegiatan penelitian Balar Banjarmasin (74.24\%), diikuti dengan ekploratif sebanyak $21.97 \%$ (lihat tabel 12). Sementara itu, penelitian eksplanatif tampaknya masih sepi peminat, dengan komposisi $3.79 \%$. Sebanyak $0.76 \%$ lainnya adalah penelitian yang tidak dapat dikategorikan dalam ketiga tipe tersebut.

Parameter penelitian yang dilakukan secara tepat terdapat pada $31.03 \%$ penelitian eksploratif dan $75.5 \%$ penelitian deskriptif (lihat tabel 13 dan 14). Hal tersebut terlihat dengan adanya pola yang selaras antara perumusan masalah, model penalaran, dan teknik pengumpulan data, serta pemaparan pada pembahasan dan simpulan. Hasil penelitian eksploratif yang ditulis di dalam LPA memberikan petunjuk mengenai potensi dan bentuk data arkeologi yang direkomendasikan untuk penelitian lanjutan. Uraian LPA penelitian deskriptif memberikan gambaran mengenai data arkeologi yang diteliti serta penjelasan lainnya yang sesuai dengan masing-masing permasalahan yang sudah dirumuskan.

Penelitian yang dapat dikelompokkan sebagai gabungan sifat eksplorasi-deskripsi terdiri atas $20.69 \%$ penelitian eksploratif dan $4.1 \%$ penelitian deskriptif. Penelitian eksploratif- 
Tabel 12. Tipe Penelitian dalam LPA Balar

Banjarmasin

\begin{tabular}{|l|r|r|}
\hline \multicolumn{1}{|c|}{ Jenis } & Jumlah & \multicolumn{1}{c|}{$\%$} \\
\hline Eksploratif & 29 & 21.80 \\
\hline Deskriptif & 98 & 72.93 \\
\hline Eksplanatif & 6 & 4.51 \\
\hline Lain-lain & 1 & 0.75 \\
\hline
\end{tabular}

Tabel 13. Penerapan Penelitian Eksploratif di Balar Banjarmasin

\begin{tabular}{|l|r|c|}
\hline \multicolumn{1}{|c|}{$\begin{array}{c}\text { Pemilihan Tipe } \\
\text { Penelitian }\end{array}$} & Jumlah & $\%$ \\
\hline tepat (eksploratif) & 9 & $31.03 \%$ \\
\hline $\begin{array}{l}\text { gabungan } \\
\text { (eksploratif-deskriptif) }\end{array}$ & 6 & $20.69 \%$ \\
\hline $\begin{array}{l}\text { kurang tepat } \\
\text { (seharusnya deskriptif) }\end{array}$ & 11 & $37.93 \%$ \\
\hline tidak dapat dijelaskan & 3 & $10.34 \%$ \\
\hline
\end{tabular}

deskriptif ini memiliki rumusan masalah yang membutuhkan lebih dari sekedar uraian data arkeologi yang diperoleh, serta bertujuan untuk menjelaskan hubungan antardata yang lebih kompleks. Hal yang perlu mendapat perhatian yaitu bahwa sebanyak $37.93 \%$ penelitian eksploratif dan $20.4 \%$ penelitian deskriptif 6 ternyata tidak sepenuhnya tepat. Kekurangtepatan tersebut tampak pada tidak adanya harmoni antara sifat penelitian yang tercermin pada judul; bentuk rumusan permasalahan; pertimbangan pilihan dalam metode penelitian yang meliputi sifat, teknik pengumpulan data, dan analisis; serta pemaparan uraian data maupun simpulan. Hasil penelitian yang diuraikan pun dikhawatirkan dapat membingungkan pembaca karena alur pikir dalam uraian tidak runut. Masalah ini perlu digarisbawahi mengingat pembaca LPA tidak hanya dari kalangan arkeolog saja, tetapi juga masyarakat luas yang awam terhadap ilmu arkeologi. Uraian hasil penelitian pada LPA sudah seharusnya menjadi salah satu rujukan utama mengenai informasi arkeologi.

Sejumlah 10.34\% LPA penelitian eksploratif tidak dapat diamati secara lebih rinci karena
Tabel 14. Penerapan Penelitian Deskriptif di Balar Banjarmasin

\begin{tabular}{|l|r|r|}
\hline \multicolumn{1}{|c|}{$\begin{array}{c}\text { Pemilihan Tipe } \\
\text { Penelitian }\end{array}$} & Jumlah & $\%$ \\
\hline tepat (deskriptif) & 74 & $75.5 \%$ \\
\hline $\begin{array}{l}\text { gabungan (eksploratif- } \\
\text { deskriptif) }\end{array}$ & 4 & $4.1 \%$ \\
\hline tidak dapat dijelaskan & 20 & $20.4 \%$ \\
\hline
\end{tabular}

parameter hanya bisa diamati dari judul saja. Uraian pemaparan LPA tersebut tidak memiliki parameter penelitian yang dapat diidentifikasi, sehingga hubungan antarvariabel dalam skema penulisan tidak dapat dilihat. Kelompok LPA ini tidak memiliki rumusan permasalahan yang menjadi dasar utama dari kegiatan penelitian. Ketiadaan rumusan ini menjadikan LPA tidak dapat diketahui apakah permasalahan dalam penelitian terjawab atau belum. Tujuan dan sasaran penelitian sendiri menjadi tidak jelas. Sama halnya dengan $20.4 \%$ jumlah penelitian deskriptif yang juga tidak memiliki parameter penelitian yang jelas. Tujuan penelitian tidak tergambar melalui uraian pemaparan, mengingat tidak adanya rumusan permasalahan yang diajukan.

Kecenderungan lain yang menonjol adalah tingginya animo penggunaan metode induktif pada semua kegiatan penelitian di Balar Banjarmasin. Pengamatan terhadap LPA tidak menemukan penelitian yang dilakukan secara deduktif. Kajian terhadap proposal penelitian tahun 2009-2013 terdapat 4 buah kegiatan yang direncanakan dilakukan dengan metode induktifdeduktif (Hindarto 2013: 11-13). Hal ini dirasa menjadi angin segar di tengah gersangnya penerapan pemikiran deduktif dalam kegiatan penelitian di Balar Banjarmasin. Akan tetapi, pada saat kajian LPA dilakukan, dari keempat penelitian tersebut hanya terdapat satu LPA yang ditemukan. Penelitian yang membahas mengenai arkeologi urban di wilayah Kabupaten Paser ini mengajukan hipotesis sebagai jawaban sementara akan

$6 \quad$ Penentuan tipe penelitian eksploratif lebih ditentukan oleh penggunaan kata 'eksplorasi' atau eksploratif' dalam judulnya; sedangkan tipe deskriptif ditentukan oleh asumsi penulis berdasarkan bentuk uraian data pada pemaparan LPA.

$7 \quad$ Penelitian Indianisasi di Kalimantan Bagian Barat (2010); Penelitian Seni Bina Kota dan Seni Bangunan Sebagai Wujud Transformasi Pasca Kolonial di Kalimantan Selatan (2010); Penelitian Arkeologi Urban di Wilayah Bekas Kerajaan Paser, Kalimantan Timur (2011); Penelitian Eksplorasi di Kabupaten Sambas (2012) (dirangkum dari Hindarto, 2013: 1-13). 
permasalahan yang dihadapi (Tim Peneliti 2011: 6). Sementara tiga LPA yang lainnya yang tidak ditemukan tentu saja tidak dapat dikaji lebih lanjut. Tidak ditemukannya ketiga LPA tersebut mengindikasikan adanya beberapa kemungkinan, yaitu penelitian tidak dilaksanakan atau penelitian sudah dilaksanakan tetapi LPA sebagai keluaran akhir kegiatan selesai disusun.

Hal lain yang perlu menjadi pemikiran bersama adalah kurangnya perhatian pada metode pengumpulan dan analisis data yang dilakukan. Pengumpulan data seharusnya dilakukan dengan melihat data arkeologi sebagai satu kesatuan konteks. Metode pengumpulan data perlu direncanakan secara cermat untuk memaksimalkan kualitas data arkeologi dalam rangka memahami budaya dan tingkah laku masa lalu (Sharer dan Ashmore 2003: 140). Pada kenyataannya, pengumpulan data yang dilakukan dalam kegiatan penelitian hanya menjadi rutinitas dalam perjalanan di lapangan. Belum ada standar minimal perekaman data dalam kegiatan penelitian menyebabkan catatan lapangan dibuat dan disusun sesuai dengan kebiasaan masingmasing peneliti. Tanudirdjo (1993: 70) mengatakan bahwa pengumpulan data arkeologi di Indonesia masih bersifat arbitrer, sesuai dengan keinginan masing-masing peneliti. Pengumpulan data seperti ini belum memandang data dan konteks arkeologi merupakan satu kesatuan yang tidak dapat dipisahkan. Tahapan pengumpulan data yang diuraikan dalam LPA hanya sekedarnya saja, tanpa ada gambaran langkah nyata yang diambil di lapangan. Tidak adanya standar minimal dalam perekaman data, menyebabkan pencatatan dan pendokumentasian data tidak dapat dilakukan secara maksimal. Padahal, kualitas data arkeologi sangat dipengaruhi oleh cara perolehan dan penangannya. Hal seperti ini tampak pada metode ekskavasi yang sering diterapkan dalam penelitian arkeologi di Balar Banjarmasin. Sistem spit cenderung lebih disukai daripada sistem lot yang menggabungkan spit dan layer. Tabulasi temuan pada laporan pun disusun hanya berdasarkan posisi kedalaman dengan satuan ukur tertentu, tanpa menyebutkan lapisan tanah aslinya. Metode pengumpulan data juga terjebak pada teknik yang "itu-itu" saja.

Hasil pengamatan menunjukkan bahwa sebagian penelitian arkeologi yang dilakukan tidak memiliki langkah analisis data yang jelas dalam metode penelitiannya ${ }^{8}$. Gambaran ini memberikan pemahaman bahwa kegiatan penelitian di Balar Banjarmasin lebih menekankan kepada aktivitas pengumpulan data arkeologi. Penanganan data dengan menggunakan sejumlah perangkat analisis belum dilakukan secara maksimal. Uraian deskripsi data arkeologi yang ditemukan juga memiliki kecenderungan disusun berdasarkan sudut pandang peneliti, tanpa tahapan analisis yang jelas. Kalaupun ada, analisis yang dilakukan baru sekedar proses klasifikasi awal dan analisis umum terkait dengan morfologi dan tipologi. Meskipun tanpa penjelasan mengenai tahapan analisis data, uraian pemaparan pada pembahasan dianggap dapat memberikan gambaran mengenai keberadaan data arkeologi di suatu situs.

\section{Permasalahan Penelitian dalam Laporan Penelitian Arkeologi di Balar Banjarmasin}

Pemaparan yang telah diuraikan sebelumnya memberikan indikasi bahwa terdapat permasalahan serius terkait dengan pelaksanaan penelitian dan penulisan hasilnya dalam LPA di Balar Banjarmasin. Secara umum, permasalahan dalam penelitian arkeologi di Indonesia sudah sering disampaikan oleh beberapa ahli. Pada diskusi PIA IV ${ }^{9}$, Mundardjito telah menyoroti kecenderungan tidak adanya minat pada penggunaan deduktif sebagai dasar penalaran pada tulisan di tiga sidang seminar PIA (tahun 1977, 1980, dan 1983). Mundardjito (1986: 197203) mengatakan bahwa penelitian induktif saja tidak dapat menciptakan dan mengembangkan hipotesis dan teori arkeologi, sehingga beliau menyarankan adanya penggabungan model

Sebanyak $93 \%$ penelitian eksploratif tidak memiliki analisis data, demikian pula hanya dengan $42 \%$ penelitian deskriptif.

Pertemuan Ilmian Arkeologi yang dilaksanakan oleh IAAI (Ikatan Ahli Arkeologi Indonesia) di Cipanas, 3-9 Maret 1986. 
induktif-deduktif untuk mendapatkan hasil penelitian yang mantap dengan cakupan yang luas. Tampaknya, hal ini juga masih menjadi permasalahan di Balar Banjarmasin yang sebagian besar penelitiannya masih induktif.

Masalah lain dalam penelitian arkeologi diungkapkan oleh Tanudirdjo (1993: 67-96). Masalah yang umum ditemui antara lain perhatian terhadap data arkeologi dan teknik pengumpulan data yang belum memperhatikan konteks dan sebarannya, sehingga hanya diamati secara arbitrer. Selain itu, Tanudirdjo juga mengungkapkan masalah mengenai kurangnya perhatian peneliti terhadap proses bernalar dalam penelitian arkeologi serta terbatasnya minat terhadap penelitian eksplanatif dalam arkeologi Indonesia (Tanudirdjo 1993: 82-83). Sementara itu, Sulistyanto (2001: 18-21) mengungkapkan salah satu masalah dalam publikasi hasil penelitian arkeologi kepada masyarakat luas yang terhambat oleh terbatasnya kuantitas terbitan, serta kesulitan pembaca untuk dapat memahami uraian dalam laporan arkeologi. Hal tersebut disebabkan karena semua uraian hasil penelitian baik berupa LPA yang belum diterbitkan maupun artikel pada jurnal ilmiah cenderung terformat untuk kalangan terbatas.

Kajian terhadap laporan hasil penelitian arkeologi Balar Banjarmasin mengidentifikasi permasalahan mendasar yang perlu dipikirkan secara serius. Permasalahan tersebut dibagi dalam dua kelompok, yaitu masalah akademis dan masalah teknis. Masalah akademis dalam penelitian arkeologi Balar Banjarmasin adalah halhal yang terkait dengan belum dilakukannya parameter serta prosedur penelitian yang benar. Masalah akademis ini terdiri atas pemilihan jenis penelitian yang kurang tepat, pertimbangan dalam perumusan permasalahan, pemilihan metode analisis yang belum sesuai, dan kurangnya kajian pustaka. Hasil kajian juga menunjukkan bahwa penelitian arkeologi Balar Banjarmasin masih terjebak paradigma lama, arkeologi tradisional.

Gabungan dari permasalahan tersebut menyebabkan tidak adanya harmoni dalam alur pemaparan hasil penelitian arkeologi. Sebagai implikasinya pembaca akan mengalami kebingungan dalam memahami data arkeologi.
Sekali lagi perlu dipahami, bahwa pengguna laporan penelitian adalah masyarakat luas yang pada umumnya awam terhadap ilmu arkeologi. Dampak yang lebih parah, adalah penelitian arkeologi yang tidak taat prosedur akan berimplikasi pada kualitas data dan interpretasi yang diragukan keilmiahannya.

Masalah teknis penelitian arkeologi meliputi dua hal utama, yaitu belum ada format standar dan kontrol kualitas kegiatan penelitian di Balar Banjarmasin. Format standar penelitian dapat diartikan sebagai panduan akademis pelaksanaan penelitian yang disusun sesuai dengan prosedur penelitian yang tepat. Format standar tersebut mencakup seluruh tahapan yang dilakukan dalam kegiatan penelitian arkeologi di Balar Banjarmasin, yang meliputi kegiatan pralapangan, lapangan, dan pascalapangan. Tahapan pralapangan yang paling utama adalah penyusunan proposal penelitian. Masalah utama dalam penyusunan proposal adalah kekurangpeduliannya peneliti pada standar format proposal yang ada, sehingga dari tahun ke tahun proposal disusun dengan bentuk yang beragam. Selain itu, masalah penyusunan proposal juga terkait dengan aspek ilmiah dalam penelitian yang belum terpenuhi. Kegiatan pengumpulan data di lapangan juga belum memiliki standar baku yang dapat dijadikan panduan. Hal ini sering menyebabkan lemahnya strategi penelitian yang diterapkan di lapangan. Langkah-langkah pengumpulan data lebih banyak merupakan hasil improvisasi tim peneliti ketika menghadapi kondisi di lapangan. Ketidaksiapan strategi penelitian juga merupakan rangkaian dari lemahnya formulasi penelitian yang dituangkan dalam proposal. Rangkaian permasalahan tersebut menjadi efek bola salju pada kegiatan pascalapangan. Faktanya, data arkeologi yang dikumpulkan pada akhirnya hanya tersimpan di gudang artefak tanpa ada perhatian lebih lanjut. Sedikit sekali penelitian dilakukan berlanjut dengan kegiatan pascalapangan (analisis data) yang sistematis.

Masalah teknis dalam kegiatan pascalapangan lainnya, yaitu tidak adanya format standar dan kontrol kualitas laporan penelitian. Kajian ini menemukan format penulisan LPA 
dilakukan sesuai dengan gaya masing-masing peneliti. Penentuan warna sampul LPA juga tidak seragam, meskipun sebenarnya telah ada panduan tersendiri untuk pilihan warna yang tepat ${ }^{10}$. Sementara itu, kualitas data ${ }^{11}$ arkeologi yang dipaparkan dalam LPA juga beragam, ada yang hanya sekedarnya diuraikan, dan ada yang diuraikan secara detil. Hal ini disebabkan karena selama ini tidak pernah ada kontrol dan evaluasi terhadap pelaksanaan penelitian dan penulisan laporannya. Satu-satunya bentuk evaluasi yang dilakukan hanyalah pemaparan cerita kegiatan di lapangan sebagai 'oleh-oleh' yang disampaikan pada diskusi peneliti.

\section{Tawaran Solusi}

Pemaparan di atas dapat dijadikan sebagai cermin bagi seluruh tahapan kegiatan penelitian arkeologi Balar Banjarmasin. Seperti yang diungkapkan oleh Daud Tanudirdjo (1993: 68) bahwa evaluasi terhadap kegiatan penelitian arkeologi memang bukan hal yang baru. Materi yang dibahas sebenarnya adalah hal yang setiap hari digeluti dan bukan sesuatu yang baru bagi para peneliti arkeologi. Hanya saja, seperti ungkapan yang sering muncul, bahwa sesuatu yang terlalu sering dilakukan cenderung membuat orang terlena.

Retrospeksi dan evaluasi harus selalu dilakukan untuk menjaga ritme dan konsistensi ilmiah dalam setiap kegiatan penelitian arkeologi di Balar Banjarmasin. Kontrol terhadap kualitas kegiatan penelitian perlu dilakukan pada setiap lini, sehingga dapat diperoleh hasil penelitian seperti yang diharapkan. Kontrol dan evalusai kegiatan penelitian Balar Banjarmasin dapat ditetapkan melalui serangkaian kebijakan yang ditujukan untuk peningkatan kualitas penelitian arkeologi. Kontrol kualitas yang dilakukan harus menyeluruh pada semua tahapan dalam kegiatan penelitian. Untuk melakukan kontrol tersebut perlu dibentuk divisi khusus yang bertugas untuk mengawal seluruh kegiatan penelitian yang ada di Balar Banjarmasin. Peran dari divisi ini sebatas mengawal konsistensi prosedur dan keilmiahan pada pelaksanaan kegiatan sesuai dengan visi dan misi lembaga.

Gambaran bentuk kontrol yang dilakukan dapat digambarkan seperti tampak pada bagan di gambar 4. Pada bagan tersebut dapat dilihat, bahwa kegiatan penelitian merupakan suatu proses terpadu antara kegiatan pralapangan sampai dengan pascalapangan. Proposal penelitian disusun sebagai pondasi dasar seluruh pelaksanaan kegiatan. Oleh karena itu, proposal penelitian perlu direncanakan dan disusun secara matang, sehingga dapat memberi arah penelitian yang jelas. Proposal juga menjadi dasar untuk menentukan strategi penelitian selanjutnya, terkait dengan pengumpulan data di lapangan dan metode analisis data yang digunakan. Divisi kontrol di sini berperan untuk menentukan format standar dan melakukan evaluasi pada setiap proposal yang diajukan sebelum dibahas dalam sebuah diskusi ilmiah internal Balar Banjarmasin. Format standar juga perlu disusun untuk tahap pengumpulan dan perekaman data di lapangan. Hal ini bertujuan untuk meningkatkan kualitas setiap data arkeologi yang dikumpulkan dan direkam. Seluruh hasil pencatatan dan dokumentasi tim peneliti di lapangan kemudian dikumpulkan oleh divisi kontrol untuk bahan evaluasi hasil dan disimpan sebagai bagian dari laporan hasil penelitian.

Divisi kontrol juga menyusun format standar untuk kegiatan pascalapangan, yaitu analisis data dan penyusunan laporan hasil penelitian. Hal ini dilakukan untuk menjaga kualitas LPA sebagai keluaran dari seluruh rangkaian kegiatan penelitian. Penelitian arkeologi belum dapat dikatakan selesai apabila LPA belum selesai dan dicetak. Batas waktu penyusunan dan penyelesaian LPA dapat ditentukan berdasarkan

10 Kesepakatan internal Balar Banjarmasin pada tahun 2002 menetapkan jenis warna sampul LPA berdasarkan tema penelitian, yaitu merah untuk prasejarah, kuning untuk Hindu-Budha, hijau untuk Islam, biru untuk kolonial, coklat untuk etnoarkeologi. Penentuan warna sampul yang diputuskan oleh Pusat Penelitian dan Pengembangan Arkeologi Nasional pada tahun 2011 menetapkan bahwa sampul LPA yang dikirim ke pusat harus seragam (komunikasi personal, Bambang Sakti Wiku Atmojo, 5 Mei 2015).

11 Di sini saya tidak menyebutkan kualitas penulisan, karena gaya masing-masing peneliti dalam menulis tentunya tidak sama dan tidak dapat diukur secara objektif. 


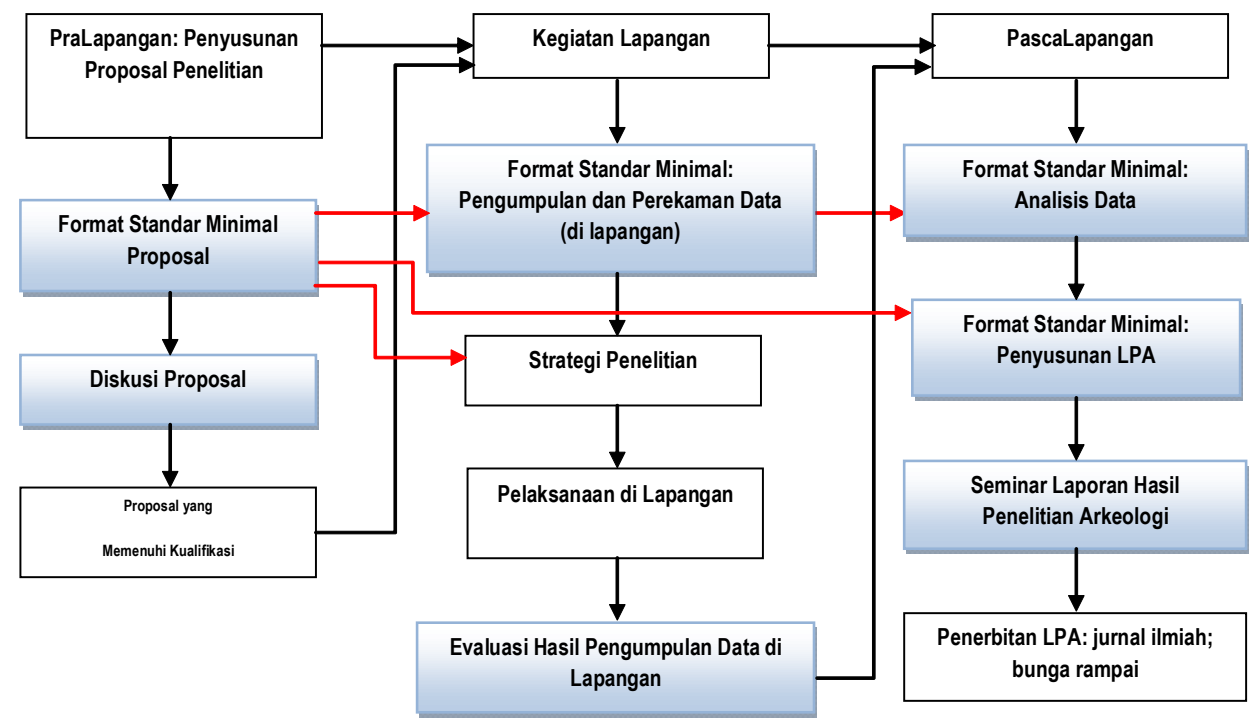

Gambar 4. Usulan skema tahapan penelitian arkeologi

kesepakatan antara pimpinan, divisi kontrol, dan peneliti di lingkungan Balar Banjarmasin. Evaluasi LPA juga dilakukan melalui seminar hasil kegiatan penelitian arkeologi dengan mengundang lembaga atau instansi lain di luar Balar Banjarmasin. Seminar ini juga merupakan suatu bentuk kegiatan publikasi hasil penelitian arkeologi kepada masyarakat umum. Keluaran atau ouput kegiatan seminar ini dapat diterbitkan dalam bentuk buku atau jurnal ilmiah dan disebarluaskan kepada masyarakat.

\section{PENUTUP}

Sejumlah penelitian arkeologi sudah dilakukan oleh Balar Banjarmasin dalam kurun waktu 1993-2013. Luasnya wilayah kerja, keterbatasan sumber daya manusia, waktu pelaksanaan, dan pendanaan menjadi kendala tersendiri dalam pelaksanaan kegiatan penelitian. Secara umum, kegiatan penelitian di Balar Banjarmasin sudah berjalan dengan baik. Pengamatan terhadap LPA sebagai output kegiatan, penelitian arkeologi Balar Banjarmasin terdiri atas tiga jenis, yaitu eksploratif, deskriptif atau eksplikatif, dan eksplanatif. Penelitian yang dilakukan memiliki beberapa kecenderungan, yaitu sebagian besar merupakan penelitian deskriptif. Model penalaran induktif menjadi metode yang paling digemari dan menjadi pilihan utama dalam kegiatan penelitian arkeologi. Hal lain yang tampak pada LPA yaitu kurangnya perhatian pada metode penelitian arkeologi yang meliputi model penalaran, teknik pengumpulan data, dan analisis data yang digunakan.

Selain itu, permasalahan mendasar yang muncul adalah ketidakkonsistenan pada penyusunan LPA, baik secara format maupun alur pikir dalam pemaparan. Masalah tersebut sebenarnya sudah terjadi pada saat penyusunan proposal dilakukan. Efek dari masalah dalam proposal kemudian terus bergulir, sehingga tidak ada keharmonisan dalam seluruh rangkaian kegiatan penelitian. Untuk itu, perlu dipikirkan sebuah skema tahapan penelitian arkeologi yang terpadu, yang dapat memberikan arah yang jelas pada setiap kegiatan penelitian. Pelaksanaan penelitian yang terarah dan taat pada kaidah ilmiah diharapkan memberikan hasil yang dapat dipertanggungjawabkan kualitasnya secara ilmiah. Hasil penelitian yang dipublikasikan dengan baik harapannya dapat diterima oleh masyarakat luas, yang asing dengan ilmu arkeologi. 


\section{DAFTAR PUSTAKA}

Binford, Lewis R. 1971. "Archaeological Perspectives. HIm. 155-186 dalam James Deetz ed. Man's Imprint From the Past Reading in the Methods of Archaeology. Boston: Little Brown Company.

Fajari, Nia M. E. dan Vida Pervaya Rusianti Kusmartono. 2013. "The Excavation of Gua Payung, South Kalimantan, Indonesia". Hal. 20-33 dalam Bulletin of Indo Pacific Prehistoric Archaeology 33.

Gibbon, Guy. 1984. Anthropological Archaeology. New York. Columbia University Press.

Hindarto, Imam. 2013. "Praktek Penelitian Balai Arkeologi Banjarmasin 2009-2012". Makalah pada Seminar EHPA Medan, November 2013.

Mundarjito. 1986. "Metode induktif-Deduktif dalam Penelitian Arkeologi di Indonesia". HIm. 197-203 dalam PIA IV Buku III: Konsep dan Metodologi. Jakarta: Pusat Penelitian Arkeologi Nasional.

Pemerintah Republik Indonesia. 1993. (SK) Menteri Pendidikan dan Kebudayaan No. 0274/0/1993 tentang pembentukan tiga Balai Arkeologi.

Pemerintah Republik Indonesia. 2003. SK Menteri Kebudayaan dan Pendidikan Nomor 33 Tahun 2013 tentang organisasi dan tata kerja Balai Arkeologi.

Sedyawati, Edi. 2001. "Harapan Masyarakat Terhadap Kajian Arkeologi: Pengembangan Wawasan". Makalah pada Seminar EHPA 2001, Kaliurang, 1821 September 2001.

Sharer, Robert J. dan Wendy Ashmore. 2003. Archaeology Ddiscovering Our Past. New York: McGraw-Hill.

Simanjutak, Truman, Yusmaini Eriawati, Machi Suhadi, Bagyo Prasetyo, Naniek Harkantiningsih, dan Retno Handini. 1999. Metode Penelitian Arkeologi. Jakarta: Pusat Penelitian Arkeologi Nasional.

Sugiyanto, Bambang. 2008. "Survei Eksploratif Gua-gua Prasejarah di Kabupaten Tanah
Bumbu". LPA. Banjarbaru: Balai Arkeologi Banjarmasin.

Sulistyanto, Bambang. 2001. "Orientasi Penelitian Arkeologi: Suatu Upaya Retrospeksi”. Makalah pada Seminar EHPA Kaliurang, 18-21 September 2001.

Tanudirjo, Daud Aris. 1989. Ragam Metoda Penelitian Arkeologi dalam Skripsi Karya Mahasiswa Arkeologi UGM". LPA. Yogyakarta: Universitas Gadjah Mada. 1993. "Retrospeksi Penelitian Arkeologi di Indonesia". Hal. 67-96 dalam Prosiding PIA VI. Jakarta: Pusat Penelitian Arkeologi Nasional.

Tim Peneliti. 2011. "Penelitian Arkeologi Urban Bekas Wilayah Kerajaan Paser di Kota Tanah Grogot Kabupaten Paser, Provinsi Kalimantan Timur". LPA. Banjarbaru: Balai Arkeologi Banjarmasin.

Tim Penyusun. 1995. Kamus Besar Bahasa Indonesia. Jakarta: Depdikbud.

Wasita. "Penelitian Sistem Penguburan pada Masyarakat Dayak Lawangan di Barito Selatan". LPA. Banjarbaru: Balai Arkeologi Banjarmasin.

2014. "Mengungkap Penelitian di Balai Arkeologi Banjarmasin: Sebagian Besar Belum Final". Naditira Widya 8 (1): 105126.

Wasita dan Sunarningsih. 2003. "Tata Cara Prosesi Penguburan dan Upacara ljambe di Kecamatan Dusun Timur, Kabupaten Barito Timur, Kalimantan Tengah". LPA. Banjarbaru: Balai Arkeologi Banjarmasin.

Wibisono, Nanik Harkantiningsih dan Vida Pervaya Rusianti Kusmartono. 1995. Survei Eksploratif Arkeologi di Provinsi Kalteng". LPA. Banjarmasin: Balai Arkeologi Banjarmasin.

Widianto, Harry dan Retno Handini. 2003. "Karakteristik Budaya Prasejarah di Kawasan Gunung Batubuli, Kalimantan Selatan: Mekanisme Hunian Gua PascaPlestosen". Berita Penelitian Arkeologi 12. 


\section{LAMPIRAN.}

Tabel 1. Daftar Judul LPA Eksploratif di Balar Banjarmasin Tahun 1993-2013.

\begin{tabular}{|c|c|c|c|c|c|c|c|c|c|}
\hline \multirow[t]{2}{*}{ No } & \multirow[t]{2}{*}{ Tahun } & \multirow[t]{2}{*}{ Judul } & \multirow[t]{2}{*}{ Pemasalahan } & \multicolumn{4}{|c|}{ Metode Penelitian } & \multirow[t]{2}{*}{ Ke simpulan } & \multirow[t]{2}{*}{ Ket } \\
\hline & & & & Sifat & Penalaran & $\begin{array}{c}\text { Pengumpulan } \\
\text { Data }\end{array}$ & $\begin{array}{l}\text { Metode } \\
\text { Analisis }\end{array}$ & & \\
\hline 1 & 1993 & $\begin{array}{l}\text { Penelitian } \\
\text { Arkeologi } \\
\text { Kotawaringin } \\
\text { Barat, } \\
\text { Kalimantan } \\
\text { Tengah } \\
\end{array}$ & $\begin{array}{l}\text { apa bentuk } \\
\text { dan seb aran } \\
\text { data? }\end{array}$ & eksploratif & induktif & $\begin{array}{l}\text { survei-studi } \\
\text { pustaka }\end{array}$ & $\begin{array}{l}\text { tidak } \\
\text { dise butkan }\end{array}$ & $\begin{array}{l}\text { permasalahan } \\
\text { terjawab }\end{array}$ & tepat \\
\hline 2 & 1993 & $\begin{array}{l}\text { Penelitian } \\
\text { Arkeologi } \\
\text { Islam di } \\
\text { Daerah } \\
\text { Pagatan dan } \\
\text { Sekitamya } \\
\text { Kabupaten } \\
\text { Kotabaru, } \\
\text { Kalimantan } \\
\text { Selatan } \\
\end{array}$ & $\begin{array}{l}\text { apa bentuk } \\
\text { data }\end{array}$ & $\begin{array}{l}\text { tidak } \\
\text { disebutkan }\end{array}$ & $\begin{array}{l}\text { tidak } \\
\text { disebutkan }\end{array}$ & $\begin{array}{l}\text { survei-studi } \\
\text { pustaka- } \\
\text { wawancara }\end{array}$ & $\begin{array}{l}\text { tidak } \\
\text { dise butkan }\end{array}$ & $\begin{array}{l}\text { tidak } \\
\text { teridentifikasi }\end{array}$ & $\begin{array}{l}\text { tidak dapat } \\
\text { diidentifika } \\
\text { si }\end{array}$ \\
\hline 3 & 1994 & $\begin{array}{l}\text { Survei } \\
\text { Eksploratif } \\
\text { Situs-situs } \\
\text { Pra sejarah di } \\
\text { Wilayah } \\
\text { Tabalong, } \\
\text { Provinsi } \\
\text { Kalimantan } \\
\text { Selatan } \\
\end{array}$ & apa potensi & eksploratif & induktif & survei & $\begin{array}{l}\text { tidak } \\
\text { dise butkan }\end{array}$ & $\begin{array}{l}\text { permasalahan } \\
\text { terjawab }\end{array}$ & tepat \\
\hline 4 & 1994 & $\begin{array}{l}\text { Survei } \\
\text { Eksploratif di } \\
\text { Wilayah } \\
\text { Provinsi } \\
\text { Kalimantan } \\
\text { Selatan }\end{array}$ & apa potensi & eksploratif & induktif & survei & $\begin{array}{l}\text { tidak } \\
\text { dise butkan }\end{array}$ & $\begin{array}{l}\text { permasalahan } \\
\text { terjawab }\end{array}$ & tepat \\
\hline 5 & 1995 & $\begin{array}{l}\text { Survei } \\
\text { Eksploratif } \\
\text { Arkeologi di } \\
\text { Provinsi } \\
\text { Kalimantan } \\
\text { Tengah }\end{array}$ & $\begin{array}{l}\text { apa potensi; } \\
\text { bagaimana } \\
\text { pemukiman } \\
\text { dan } \\
\text { aktivitasnya }\end{array}$ & deskriptif & induktif & survei & $\begin{array}{l}\text { tidak } \\
\text { dise butkan }\end{array}$ & $\begin{array}{l}\text { permasalahan } \\
\text { terjawab }\end{array}$ & $\begin{array}{l}\text { kurang } \\
\text { tepat } \\
\text { (deskriptif) }\end{array}$ \\
\hline 6 & 1995 & $\begin{array}{l}\text { Survei Gua- } \\
\text { gua di } \\
\text { Pegunungan } \\
\text { Muller } \\
\text { Kecamatan } \\
\text { Sangkulirang, } \\
\text { Kabupaten } \\
\text { Kutai, } \\
\text { Kalimantan } \\
\text { Timur } \\
\end{array}$ & $\begin{array}{l}\text { bagaimana } \\
\text { persebaran } \\
\text { lukisan gua }\end{array}$ & eksploratif & induktif & survei & $\begin{array}{l}\text { tidak } \\
\text { dise butkan }\end{array}$ & $\begin{array}{l}\text { permasalahan } \\
\text { terjawab }\end{array}$ & $\begin{array}{l}\text { kurang } \\
\text { tepat } \\
\text { (deskriptif) }\end{array}$ \\
\hline 7 & 1996 & $\begin{array}{l}\text { Survei } \\
\text { Eksplorastif } \\
\text { Arkeologi di } \\
\text { Provinsi } \\
\text { Kalimantan } \\
\text { Timur }\end{array}$ & $\begin{array}{l}\text { apa potensi; } \\
\text { bagaimana } \\
\text { perkembangan } \\
\text { bu dayanya? }\end{array}$ & deskriptif & induktif & survei & $\begin{array}{l}\text { tidak } \\
\text { dise butkan }\end{array}$ & $\begin{array}{l}\text { permasalahan } \\
\text { belum } \\
\text { terjawab }\end{array}$ & $\begin{array}{l}\text { kurang } \\
\text { tepat } \\
\text { (deskriptif) }\end{array}$ \\
\hline
\end{tabular}




\begin{tabular}{|c|c|c|c|c|c|c|c|c|c|}
\hline \multirow[t]{2}{*}{ No } & \multirow[t]{2}{*}{ Tahun } & \multirow[t]{2}{*}{ Judul } & \multirow[t]{2}{*}{ Pe masalahan } & \multicolumn{4}{|c|}{ Metode Penelitian } & \multirow[t]{2}{*}{ Kesimpulan } & \multirow[t]{2}{*}{ Ket } \\
\hline & & & & Sifat & Penalaran & $\begin{array}{c}\text { Pengumpulan } \\
\text { Data }\end{array}$ & $\begin{array}{l}\text { Metode } \\
\text { Analisis }\end{array}$ & & \\
\hline 8 & 1998 & $\begin{array}{l}\text { Survei } \\
\text { Eksploratif } \\
\text { DAS Barito } \\
\text { Tahap I, } \\
\text { Kabupaten } \\
\text { Barito Utara, } \\
\text { Kalimantan } \\
\text { Tengah }\end{array}$ & $\begin{array}{l}\text { apa potensi; } \\
\text { bagaimana } \\
\text { kehidupan } \\
\text { ma syarakatn ya } \\
?\end{array}$ & deskriptif & induktif & survei & $\begin{array}{l}\text { tidak } \\
\text { dise butkan }\end{array}$ & $\begin{array}{l}\text { permasalahan } \\
\text { belum } \\
\text { terjawab }\end{array}$ & $\begin{array}{l}\text { kurang } \\
\text { tepat } \\
\text { (deskriptif) }\end{array}$ \\
\hline 9 & 2000 & $\begin{array}{l}\text { Survei } \\
\text { Eksploratif } \\
\text { Gua-gua di } \\
\text { Wilayah } \\
\text { Kabupaten } \\
\text { Pasir, } \\
\text { Provinsi } \\
\text { Kalimantan } \\
\text { Timur }\end{array}$ & tidak ada & $\begin{array}{l}\text { tidak } \\
\text { disebutkan }\end{array}$ & $\begin{array}{l}\text { tidak } \\
\text { disebutkan }\end{array}$ & $\begin{array}{l}\text { Survei- } \\
\text { wawancara }\end{array}$ & $\begin{array}{l}\text { tidak } \\
\text { dise butkan }\end{array}$ & $\begin{array}{l}\text { tidak } \\
\text { teridentifikasi }\end{array}$ & $\begin{array}{l}\text { tidak dapat } \\
\text { diidentifika } \\
\text { si }\end{array}$ \\
\hline 10 & 2000 & $\begin{array}{l}\text { Survey } \\
\text { Arkeologi di } \\
\text { Kotawaringin } \\
\text { Timur, } \\
\text { Provinsi } \\
\text { Kalimantan } \\
\text { Tengah }\end{array}$ & $\begin{array}{l}\text { apa variasi } \\
\text { bangunan } \\
\text { kubur-what; } \\
\text { bagaimana } \\
\text { kesinambunga } \\
\text { n budaya }\end{array}$ & $\begin{array}{l}\text { tidak } \\
\text { disebutkan }\end{array}$ & $\begin{array}{l}\text { tidak } \\
\text { disebutkan }\end{array}$ & $\begin{array}{l}\text { Survei- } \\
\text { wawancara }\end{array}$ & $\begin{array}{l}\text { tidak } \\
\text { dise butkan }\end{array}$ & $\begin{array}{l}\text { permasalahan } \\
\text { terjawab }\end{array}$ & $\begin{array}{l}\text { kurang } \\
\text { tepat } \\
\text { (deskriptif) }\end{array}$ \\
\hline 11 & 2001 & $\begin{array}{l}\text { Survei } \\
\text { Eksploratif } \\
\text { Gua-gua } \\
\text { Prasejarah di } \\
\text { Kecamatan } \\
\text { Babulu, } \\
\text { Kabupaten } \\
\text { Pasir, } \\
\text { Provinsi } \\
\text { Kalimantan } \\
\text { Timur }\end{array}$ & apa potensi & deskriptif & induktif & $\begin{array}{l}\text { survei- } \\
\text { wawancara }\end{array}$ & $\begin{array}{l}\text { tidak } \\
\text { dise butkan }\end{array}$ & $\begin{array}{l}\text { permasalahan } \\
\text { terjawab }\end{array}$ & $\begin{array}{l}\text { kurang } \\
\text { tepat } \\
\text { (deskriptif) }\end{array}$ \\
\hline 12 & 2002 & $\begin{array}{l}\text { Survey } \\
\text { Eksploratif } \\
\text { Pantai Timur } \\
\text { Kabupaten } \\
\text { Berau } \\
\text { Provinsi } \\
\text { Kalimantan } \\
\text { Timur }\end{array}$ & $\begin{array}{l}\text { apa potensi; } \\
\text { bagaimana } \\
\text { hubungan } \\
\text { kesejarahan } \\
\text { kehidupan } \\
\text { masa lalu }\end{array}$ & $\begin{array}{l}\text { tidak } \\
\text { disebutkan }\end{array}$ & $\begin{array}{l}\text { tidak } \\
\text { d isebutkan }\end{array}$ & $\begin{array}{l}\text { survei- } \\
\text { wawancara }\end{array}$ & $\begin{array}{l}\text { tidak } \\
\text { dise butkan }\end{array}$ & $\begin{array}{l}\text { permasalahan } \\
\text { belum } \\
\text { terjawab }\end{array}$ & $\begin{array}{l}\text { kurang } \\
\text { tepat } \\
\text { (deskriptif) }\end{array}$ \\
\hline 13 & 2002 & $\begin{array}{l}\text { Survei Gua- } \\
\text { gua } \\
\text { Prasejarah di } \\
\text { Kecamatan } \\
\text { Muara Uya, } \\
\text { Kabupaten } \\
\text { Tabalong, } \\
\text { Kalimantan } \\
\text { Selatan 9-22 } \\
\text { Juli } 2002\end{array}$ & $\begin{array}{l}\text { bagaimana } \\
\text { karakter, } \\
\text { hubungan } \\
\text { antarsitus, } \\
\text { posisi } \\
\text { Kalimantan } \\
\text { dalam arus } \\
\text { migrasi }\end{array}$ & $\begin{array}{l}\text { tidak } \\
\text { disebutkan }\end{array}$ & $\begin{array}{l}\text { tidak } \\
\text { disebutkan }\end{array}$ & $\begin{array}{l}\text { survei-studi } \\
\text { pustaka- } \\
\text { wawancara }\end{array}$ & $\begin{array}{l}\text { tidak } \\
\text { dise butkan }\end{array}$ & $\begin{array}{l}\text { permasalahan } \\
\text { belum } \\
\text { terjawab }\end{array}$ & $\begin{array}{l}\text { kurang } \\
\text { tepat } \\
\text { (deskriptif) }\end{array}$ \\
\hline
\end{tabular}




\begin{tabular}{|c|c|c|c|c|c|c|c|c|c|}
\hline \multirow[t]{2}{*}{ No } & \multirow[t]{2}{*}{ Tahun } & \multirow[t]{2}{*}{ Judul } & \multirow[t]{2}{*}{ Permas alahan } & \multicolumn{4}{|c|}{ Metode Penelitian } & \multirow[t]{2}{*}{ Kesimpulan } & \multirow[t]{2}{*}{ Ket } \\
\hline & & & & Sifat & Penalaran & $\begin{array}{c}\text { Pengumpulan } \\
\text { Data }\end{array}$ & $\begin{array}{l}\text { Metode } \\
\text { Analisis }\end{array}$ & & \\
\hline 14 & 2002 & $\begin{array}{l}\text { Survey } \\
\text { Eksploratif } \\
\text { Pantai Timur } \\
\text { Kabupaten } \\
\text { Pasir dan } \\
\text { Kutai Timur } \\
\text { Kalimantan } \\
\text { Timur }\end{array}$ & $\begin{array}{l}\text { apa potensi; } \\
\text { bagaimana } \\
\text { kehidupan } \\
\text { ekonominya? }\end{array}$ & $\begin{array}{l}\text { tidak } \\
\text { disebutkan }\end{array}$ & $\begin{array}{l}\text { tidak } \\
\text { d isebutkan }\end{array}$ & $\begin{array}{l}\text { survei- } \\
\text { wawancara }\end{array}$ & $\begin{array}{l}\text { tidak } \\
\text { disebutkan }\end{array}$ & $\begin{array}{l}\text { permasalahan } \\
\text { belum } \\
\text { terjawab }\end{array}$ & $\begin{array}{l}\text { kurang } \\
\text { te pat } \\
\text { (deskrip tif) }\end{array}$ \\
\hline 15 & 2002 & $\begin{array}{l}\text { Survei Gua- } \\
\text { gua } \\
\text { Pra sejarah di } \\
\text { Kecamatan } \\
\text { Muara Uya, } \\
\text { Kabupaten } \\
\text { Tabalong, } \\
\text { Kalimantan } \\
\text { Selatan } \\
\end{array}$ & $\begin{array}{l}\text { bagaimana } \\
\text { karakter; } \\
\text { hubungan; dan } \\
\text { posisi } \\
\text { Kalimantan } \\
\text { dalam } \\
\text { prasejarah } \\
\text { Ind onesia }\end{array}$ & $\begin{array}{l}\text { tidak } \\
\text { disebutkan }\end{array}$ & $\begin{array}{l}\text { tidak } \\
\text { disebutkan }\end{array}$ & $\begin{array}{l}\text { survei-studi } \\
\text { pustaka- } \\
\text { wawancara }\end{array}$ & $\begin{array}{l}\text { tidak } \\
\text { disebutkan }\end{array}$ & $\begin{array}{l}\text { permasalahan } \\
\text { belum } \\
\text { terjawab }\end{array}$ & $\begin{array}{l}\text { kurang } \\
\text { tepat } \\
\text { (deskrip tif) }\end{array}$ \\
\hline 16 & 2003 & $\begin{array}{l}\text { Survei } \\
\text { Eksplorasi } \\
\text { Gua-gua } \\
\text { Prasejarah di } \\
\text { Kecamatan } \\
\text { Haruai, } \\
\text { Kabupaten } \\
\text { Tabalong, } \\
\text { Provinsi } \\
\text { Kalimantan } \\
\text { Selatan }\end{array}$ & $\begin{array}{l}\text { bagaimana } \\
\text { karakter, } \\
\text { hubungan } \\
\text { antarsitus, } \\
\text { posisi } \\
\text { Kalimantan } \\
\text { dalam kerangka } \\
\text { praseja rah } \\
\text { Ind onesia }\end{array}$ & $\begin{array}{l}\text { eksplo ratif- } \\
\text { de skriptif }\end{array}$ & induktif & survei & $\begin{array}{l}\text { tidak } \\
\text { disebutkan }\end{array}$ & $\begin{array}{l}\text { permasalahan } \\
\text { belum } \\
\text { terjawab }\end{array}$ & $\begin{array}{l}\text { gabungan } \\
\text { (eksploratif } \\
\text { deskriptif) }\end{array}$ \\
\hline 17 & 2003 & $\begin{array}{l}\text { Penelitian } \\
\text { Eksploratif } \\
\text { DAS Keham, } \\
\text { Kecamatan } \\
\text { Muara Wiis, } \\
\text { Kabupaten } \\
\text { Kutai } \\
\text { Kertanegara, } \\
\text { Provinsi } \\
\text { Kalimantan } \\
\text { Timur. } \\
\end{array}$ & $\begin{array}{l}\text { apa potensi } \\
\text { bentukdan } \\
\text { sebaran }\end{array}$ & $\begin{array}{l}\text { eksplo ratif- } \\
\text { de skniptif }\end{array}$ & induktif & $\begin{array}{l}\text { survei-studi } \\
\text { pustaka }\end{array}$ & $\begin{array}{l}\text { tidak } \\
\text { disebutkan }\end{array}$ & $\begin{array}{l}\text { permasalahan } \\
\text { belum } \\
\text { terjawab }\end{array}$ & $\begin{array}{l}\text { gabungan } \\
\text { (eksploratif } \\
\text { deskriptif) }\end{array}$ \\
\hline 18 & 2003 & $\begin{array}{l}\text { Survei } \\
\text { Eksploratif } \\
\text { Pesisir Timur, } \\
\text { Kabupaten } \\
\text { Bulungan, } \\
\text { Tarakan, dan } \\
\text { Nunukan, } \\
\text { Kalimantan } \\
\text { Timur } \\
\end{array}$ & $\begin{array}{l}\text { bagaimana } \\
\text { kontinuitas } \\
\text { bu daya }\end{array}$ & eksplo ratif & induktif & $\begin{array}{l}\text { Survei- } \\
\text { wawancara }\end{array}$ & $\begin{array}{l}\text { tidak } \\
\text { disebutkan }\end{array}$ & $\begin{array}{l}\text { permasalahan } \\
\text { belum } \\
\text { terjawab }\end{array}$ & $\begin{array}{l}\text { kurang } \\
\text { tepat } \\
\text { (deskrip tif) }\end{array}$ \\
\hline 19 & 2004 & $\begin{array}{l}\text { Penelitian } \\
\text { Eksploratif } \\
\text { Gua-gua } \\
\text { Pra sejarah di } \\
\text { Kabupaten } \\
\text { Hulu Sungai } \\
\text { Selatan dan } \\
\text { Hulu Sung ai } \\
\text { Tengah }\end{array}$ & apa potensi & eksplo ratif & induktif & ekskavasi & $\begin{array}{l}\text { tidak } \\
\text { disebutkan }\end{array}$ & $\begin{array}{l}\text { permasalahan } \\
\text { terjawab }\end{array}$ & tepat \\
\hline 20 & 2008 & $\begin{array}{l}\text { Penelitian } \\
\text { Eksploratif } \\
\text { Gua-gua } \\
\text { Pra sejarah di } \\
\text { Kabuap ten } \\
\text { Tanah } \\
\text { Bumbu, } \\
\text { Kalsel }\end{array}$ & apa potensi & $\begin{array}{l}\text { tidak } \\
\text { disebutkan }\end{array}$ & $\begin{array}{l}\text { tidak } \\
\text { disebutkan }\end{array}$ & $\begin{array}{l}\text { survei- } \\
\text { ekskavasi }\end{array}$ & $\begin{array}{l}\text { tidak } \\
\text { disebutkan }\end{array}$ & $\begin{array}{l}\text { permasalahan } \\
\text { tejiawab }\end{array}$ & tepat \\
\hline
\end{tabular}




\begin{tabular}{|c|c|c|c|c|c|c|c|c|c|}
\hline \multirow[t]{2}{*}{ No } & \multirow[t]{2}{*}{ Tahun } & \multirow[t]{2}{*}{ Judul } & \multirow[t]{2}{*}{ Permas alahan } & \multicolumn{4}{|c|}{ Metode Penelitian } & \multirow[t]{2}{*}{ Kesimpulan } & \multirow[t]{2}{*}{ Ket } \\
\hline & & & & Sifat & Penalaran & $\begin{array}{c}\text { Pengumpulan } \\
\text { Data }\end{array}$ & $\begin{array}{l}\text { Metode } \\
\text { Analisis }\end{array}$ & & \\
\hline 21 & 2009 & $\begin{array}{l}\text { Penelitian } \\
\text { Eksploratif } \\
\text { Gua-gua } \\
\text { Pra sejarah di } \\
\text { Kabupaten } \\
\text { Berau dan } \\
\text { Kutai Timur } \\
\text { Kalimantan } \\
\text { Timur } \\
\end{array}$ & apa potensi & $\begin{array}{l}\text { tidak } \\
\text { disebutkan }\end{array}$ & $\begin{array}{l}\text { tidak } \\
\text { disebutkan }\end{array}$ & $\begin{array}{l}\text { survei- } \\
\text { ekskavasi }\end{array}$ & $\begin{array}{l}\text { tidak } \\
\text { disebutkan }\end{array}$ & $\begin{array}{l}\text { tidak } \\
\text { teridentifikasi }\end{array}$ & tepat \\
\hline 22 & 2010 & $\begin{array}{l}\text { Penelitian } \\
\text { Eksplorasi } \\
\text { Arkeologi di } \\
\text { Kepulauan } \\
\text { Maya } \\
\text { Karimata, } \\
\text { Kalimantan } \\
\text { Barat }\end{array}$ & $\begin{array}{l}\text { apa ragam dan } \\
\text { sebaran data; } \\
\text { ba gaim ana } \\
\text { keberla njutan } \\
\text { bu daya }\end{array}$ & eksplo ratif & induktif & $\begin{array}{l}\text { survei- } \\
\text { ekskavasi- } \\
\text { wawancara }\end{array}$ & $\begin{array}{l}\text { analisis } \\
\text { kontekstual; } \\
\text { khusus; } \\
\text { ruang; } \\
\text { komparasi; } \\
\text { etn oarkeolo } \\
\text { gi }\end{array}$ & $\begin{array}{l}\text { permasalahan } \\
\text { terjawab }\end{array}$ & tepat \\
\hline 23 & 2011 & $\begin{array}{l}\text { Penelitian } \\
\text { Eksploratif } \\
\text { Peninggalan } \\
\text { Arkeologi di } \\
\text { Kabupaten } \\
\text { Barito } \\
\text { Selatan dan } \\
\text { Barito Timur }\end{array}$ & $\begin{array}{l}\text { apa potensi } \\
\text { data }\end{array}$ & eksplo ratif & induktif & $\begin{array}{l}\text { survei- } \\
\text { wawancara }\end{array}$ & $\begin{array}{l}\text { tidak } \\
\text { disebutkan }\end{array}$ & $\begin{array}{l}\text { permasalahan } \\
\text { terjawab }\end{array}$ & tepat \\
\hline 24 & 2011 & $\begin{array}{l}\text { Penelitian } \\
\text { Eksplorasi } \\
\text { Arkeologi di } \\
\text { Kabupaten } \\
\text { Kapuas dan } \\
\text { Pulang } \\
\text { Pisau, } \\
\text { Kalimantan } \\
\text { Tengah } \\
\end{array}$ & $\begin{array}{l}\text { apa potensi } \\
\text { data }\end{array}$ & eksplo ratif & induktif & $\begin{array}{l}\text { survei- } \\
\text { wawancara }\end{array}$ & $\begin{array}{l}\text { tidak } \\
\text { disebutkan }\end{array}$ & $\begin{array}{l}\text { permasalahan } \\
\text { terjawab }\end{array}$ & tepat \\
\hline 25 & 2011 & $\begin{array}{l}\text { Penelitian } \\
\text { Eksplorasi } \\
\text { Arkeologi } \\
\text { Kabupaten } \\
\text { Kotabaru }\end{array}$ & $\begin{array}{l}\text { apa potensidan } \\
\text { bentuk data }\end{array}$ & $\begin{array}{l}\text { eksplo ratif- } \\
\text { de skriptif }\end{array}$ & induktif & $\begin{array}{l}\text { Survei- } \\
\text { wawancara }\end{array}$ & $\begin{array}{l}\text { tidak } \\
\text { disebutkan }\end{array}$ & $\begin{array}{l}\text { permasalahan } \\
\text { terjawab }\end{array}$ & $\begin{array}{l}\text { gabungan } \\
\text { (eksploratif } \\
\text { deskriptif) }\end{array}$ \\
\hline 26 & 2013 & $\begin{array}{l}\text { Eksplorasi } \\
\text { Arkeologi } \\
\text { DAS Pawan } \\
\text { Bagian Hulu } \\
\text { dan Anak } \\
\text { Sungainya di } \\
\text { Kalimantan } \\
\text { Barat } \\
\end{array}$ & apa potensi & $\begin{array}{l}\text { eksplo ratif- } \\
\text { de skriptif }\end{array}$ & induktif & $\begin{array}{l}\text { survei-studi } \\
\text { pustaka- } \\
\text { wawancara }\end{array}$ & $\begin{array}{l}\text { tidak } \\
\text { disebutkan }\end{array}$ & $\begin{array}{l}\text { permasalahan } \\
\text { terjawab }\end{array}$ & $\begin{array}{l}\text { gabungan } \\
\text { (eksploratif } \\
\text { deskriptif) }\end{array}$ \\
\hline 27 & 2005 & $\begin{array}{l}\text { Penelitian } \\
\text { Aspek } \\
\text { Keruangan } \\
\text { Pola } \\
\text { Tatakota } \\
\text { Kolonial } \\
\text { Sanga Sanga } \\
\text { di Kabupaten } \\
\text { Kutai } \\
\text { Kertanegara, } \\
\text { Provinsi } \\
\text { Kalimantan } \\
\text { Timur }\end{array}$ & $\begin{array}{l}\text { tidak } \\
\text { disebutkan }\end{array}$ & eksplo ratif & $\begin{array}{l}\text { tidak } \\
\text { disebutkan }\end{array}$ & survei & survei & $\begin{array}{l}\text { permasalahan } \\
\text { terjawab }\end{array}$ & $\begin{array}{l}\text { tidak dapat } \\
\text { diidentifika } \\
\text { si }\end{array}$ \\
\hline
\end{tabular}




\begin{tabular}{|c|c|c|c|c|c|c|c|c|c|}
\hline \multirow[t]{2}{*}{ No } & \multirow[t]{2}{*}{ Tahun } & \multirow[t]{2}{*}{ Judul } & \multirow[t]{2}{*}{ Permas alahan } & \multicolumn{4}{|c|}{ Metode Penelitian } & \multirow[t]{2}{*}{ Kesimpulan } & \multirow[t]{2}{*}{ Ket } \\
\hline & & & & Sifat & Penalaran & $\begin{array}{c}\text { Pengumpulan } \\
\text { Data }\end{array}$ & $\begin{array}{l}\text { Metode } \\
\text { Analisis }\end{array}$ & & \\
\hline 28 & 2013 & $\begin{array}{l}\text { Eksplorasi } \\
\text { Peninggalan } \\
\text { Arkeologi di } \\
\text { Kabupaten } \\
\text { Tana Tidung } \\
\text { Provinsi } \\
\text { Kalimantan } \\
\text { Utara }\end{array}$ & apa potensi & $\begin{array}{l}\text { eksplo ratif- } \\
\text { de skriptif }\end{array}$ & indu ktif & $\begin{array}{l}\text { survei- } \\
\text { wawancara }\end{array}$ & $\begin{array}{l}\text { tidak } \\
\text { disebutkan }\end{array}$ & $\begin{array}{l}\text { permasalahan } \\
\text { terjawab }\end{array}$ & $\begin{array}{l}\text { gabungan } \\
\text { (eksploratif } \\
\text { deskriptif) }\end{array}$ \\
\hline 29 & 2013 & $\begin{array}{l}\text { Penelitian } \\
\text { Arkeologi } \\
\text { DAS Kapuas } \\
\text { Bagian Hulu, } \\
\text { Kabupaten } \\
\text { Kapuas Hulu, } \\
\text { Kalimantan } \\
\text { Barat }\end{array}$ & $\begin{array}{l}\text { apa potensidan } \\
\text { kera gaman } \\
\text { data }\end{array}$ & eksplo ratif & induktif & $\begin{array}{l}\text { survei-studi } \\
\text { pustaka }\end{array}$ & $\begin{array}{l}\text { an alisis } \\
\text { artefaktual; } \\
\text { an alisis } \\
\text { khusus; } \\
\text { tabulasi }\end{array}$ & $\begin{array}{l}\text { permasalahan } \\
\text { terjawab }\end{array}$ & $\begin{array}{l}\text { gabungan } \\
\text { (eksploratif } \\
\text { deskriptif) }\end{array}$ \\
\hline
\end{tabular}

Tabel 2. Daftar Judul LPA Deskriptif di Balar Banjarmasin Tahun 1993-2013.

\begin{tabular}{|c|c|c|c|c|c|c|c|c|c|}
\hline \multirow[t]{2}{*}{ No } & \multirow[t]{2}{*}{ Tahun } & \multirow[t]{2}{*}{ Judul } & \multirow[t]{2}{*}{ Permas alahan } & \multicolumn{4}{|c|}{ Metode Penelitian } & \multirow[t]{2}{*}{ Kesimpulan } & \multirow[t]{2}{*}{ Ket } \\
\hline & & & & Sifat & Penalaran & $\begin{array}{c}\text { Pengumpulan } \\
\text { Data }\end{array}$ & $\begin{array}{l}\text { Metode } \\
\text { Analisis }\end{array}$ & & \\
\hline 1 & 1993 & $\begin{array}{l}\text { Penelitian } \\
\text { Arkeologi di } \\
\text { Situs Candi } \\
\text { Agung, } \\
\text { Kalimantan } \\
\text { Selatan }\end{array}$ & tidak ada & $\begin{array}{l}\text { tidak } \\
\text { disebutkan }\end{array}$ & $\begin{array}{l}\text { tidak } \\
\text { disebutkan }\end{array}$ & $\begin{array}{l}\text { survei- } \\
\text { ekskavasi }\end{array}$ & $\begin{array}{l}\text { analisis } \\
\text { artefaktual; } \\
\text { analisis } \\
\text { toponimi }\end{array}$ & $\begin{array}{l}\text { tidak } \\
\text { teriden tifikasi }\end{array}$ & $\begin{array}{l}\text { tidak dapat } \\
\text { dijelaskan }\end{array}$ \\
\hline 2 & 1994 & $\begin{array}{l}\text { Survei dan } \\
\text { Ekskavasi } \\
\text { Candi Laras }\end{array}$ & tidak ada & $\begin{array}{l}\text { eksplo ratif- } \\
\text { de skriptif }\end{array}$ & induktif & $\begin{array}{l}\text { survei- } \\
\text { ekskavasi }\end{array}$ & $\begin{array}{l}\text { analisis } \\
\text { artefaktual; } \\
\text { analisis } \\
\text { lingkungan }\end{array}$ & $\begin{array}{l}\text { tidak } \\
\text { teriden tifikasi }\end{array}$ & $\begin{array}{l}\text { gabungan } \\
\text { eksploratif- } \\
\text { deskriptif }\end{array}$ \\
\hline 3 & 1995 & $\begin{array}{l}\text { Survei } \\
\text { Ikonografi } \\
\text { Situs Gua } \\
\text { Gunung } \\
\text { Kombeng, } \\
\text { Provinsi } \\
\text { Kalimantan } \\
\text { Timur }\end{array}$ & $\begin{array}{l}\text { apa ciri } \\
\text { ikonografis; } \\
\text { ba gaimana latar } \\
\text { be lakang dan } \\
\text { asosiasi arca } \\
\text { dengan situs } \\
\text { lain }\end{array}$ & de skriptif & induktif & $\begin{array}{l}\text { survei-studi } \\
\text { pustaka }\end{array}$ & $\begin{array}{l}\text { analisis } \\
\text { iko nografi }\end{array}$ & $\begin{array}{l}\text { permasalahan } \\
\text { terjawab }\end{array}$ & tepat \\
\hline 4 & 1995 & $\begin{array}{l}\text { Peninjauan } \\
\text { Arkeologis di } \\
\text { Amuntai, } \\
\text { Hulu Sungai } \\
\text { Utara }\end{array}$ & $\begin{array}{l}\text { apa bentuk data } \\
\text { pemukiman }\end{array}$ & $\begin{array}{l}\text { tidak } \\
\text { disebutkan }\end{array}$ & $\begin{array}{l}\text { tidak } \\
\text { disebutkan }\end{array}$ & $\begin{array}{l}\text { survei- } \\
\text { ekskavasi }\end{array}$ & $\begin{array}{l}\text { tidak } \\
\text { disebutkan }\end{array}$ & $\begin{array}{l}\text { permasalahan } \\
\text { terjawab }\end{array}$ & $\begin{array}{l}\text { tidak dapat } \\
\text { dijelaskan }\end{array}$ \\
\hline 5 & 1995 & $\begin{array}{l}\text { Ekskavasi } \\
\text { Situs } \\
\text { Benteng } \\
\text { Tabanio } \\
\text { Tahap }\end{array}$ & $\begin{array}{l}\text { apa bentuk } \\
\text { benteng }\end{array}$ & de skriptif & induktif & ekskavasi & $\begin{array}{l}\text { tidak } \\
\text { disebutkan }\end{array}$ & $\begin{array}{l}\text { permasalahan } \\
\text { terjawab }\end{array}$ & tepat \\
\hline
\end{tabular}




\begin{tabular}{|c|c|c|c|c|c|c|c|c|c|}
\hline \multirow[t]{2}{*}{ No } & \multirow[t]{2}{*}{ Tahun } & \multirow[t]{2}{*}{ Judul } & \multirow[t]{2}{*}{ Permas alahan } & \multicolumn{4}{|c|}{ Metode Pene litian } & \multirow[t]{2}{*}{ Kesimpulan } & \multirow[t]{2}{*}{ Ket } \\
\hline & & & & Sifat & Penalaran & $\begin{array}{c}\text { Pengumpulan } \\
\text { Data }\end{array}$ & $\begin{array}{l}\text { Metode } \\
\text { Analisis }\end{array}$ & & \\
\hline 6 & 1995 & $\begin{array}{l}\text { Punan Benau } \\
\text { Masyarakat } \\
\text { Tradisional di } \\
\text { Hulu Sungai } \\
\text { Sajau, } \\
\text { Kabupaten } \\
\text { Bulungan }\end{array}$ & $\begin{array}{l}\text { tidak } \\
\text { disebutkan }\end{array}$ & deskriptif & induktif & $\begin{array}{l}\text { tidak } \\
\text { dise butkan }\end{array}$ & etnoarkeologi & $\begin{array}{l}\text { tidak } \\
\text { terid entifikasi }\end{array}$ & tepat \\
\hline 7 & 1996 & $\begin{array}{l}\text { Ekskavasi } \\
\text { Situs Gua } \\
\text { babi Tahap I- } \\
\text { II Kabupaten } \\
\text { Tabalong, } \\
\text { Kalimantan } \\
\text { Selatan }\end{array}$ & $\begin{array}{l}\text { tidak } \\
\text { disebutkan } \\
\text { secara eksplisit }\end{array}$ & deskriptif & induktif & ekskavasi & $\begin{array}{l}\text { analisis } \\
\text { artefaktual; } \\
\text { stratigrafi }\end{array}$ & jelas & tepat \\
\hline 8 & 1996 & $\begin{array}{l}\text { Ekskavasi } \\
\text { Situs Jambu } \\
\text { Hilir, } \\
\text { Kabupaten } \\
\text { Hulu Sungai } \\
\text { Selatan, } \\
\text { Kalimantan } \\
\text { Selatan }\end{array}$ & $\begin{array}{l}\text { apa potensi } \\
\text { data }\end{array}$ & de skriptif & indu ktif & ekskavasi & $\begin{array}{l}\text { analisis } \\
\text { artefaktual; } \\
\text { stratigrafi }\end{array}$ & $\begin{array}{l}\text { pe masalahan } \\
\text { terjawab }\end{array}$ & tepat \\
\hline 9 & 1996 & $\begin{array}{l}\text { Ekskavasi } \\
\text { Situs Candi } \\
\text { Agung Tahap } \\
\text { I, Kabupaten } \\
\text { Hulu Sungai } \\
\text { Utara }\end{array}$ & $\begin{array}{l}\text { tidak } \\
\text { disebutkan }\end{array}$ & de skriptif & induktif & $\begin{array}{l}\text { survei- } \\
\text { ekskavasi }\end{array}$ & $\begin{array}{l}\text { analisis } \\
\text { kualitatif; } \\
\text { analisis } \\
\text { kuantitatif; } \\
\text { analisis } \\
\text { pertanggalan }\end{array}$ & $\begin{array}{l}\text { data dapat } \\
\text { dijela skan }\end{array}$ & tepat \\
\hline 10 & 1997 & $\begin{array}{l}\text { Ekskavasi di } \\
\text { Situs Bukit } \\
\text { Brubus } \\
\text { Kabupaten } \\
\text { Kutai, } \\
\text { Kalimantan } \\
\text { Timur }\end{array}$ & apa potensi & $\begin{array}{l}\text { tidak } \\
\text { disebutkan }\end{array}$ & $\begin{array}{l}\text { tidak } \\
\text { d isebutkan }\end{array}$ & $\begin{array}{l}\text { survei- } \\
\text { ekskavasi }\end{array}$ & $\begin{array}{l}\text { tidak } \\
\text { disebutkan }\end{array}$ & $\begin{array}{l}\text { permasalahan } \\
\text { belum } \\
\text { terjawab }\end{array}$ & tepat \\
\hline 11 & 1997 & $\begin{array}{l}\text { Pemetaan } \\
\text { Situs Muara } \\
\text { Kaman, } \\
\text { Kabupaten } \\
\text { Kutai, } \\
\text { Kalimantan } \\
\text { Timur }\end{array}$ & $\begin{array}{l}\text { bagaimana } \\
\text { lingku ngan dan } \\
\text { interaksi } \\
\text { manusia } \\
\text { dengan } \\
\text { lingkungan }\end{array}$ & $\begin{array}{l}\text { tidak } \\
\text { disebutkan }\end{array}$ & $\begin{array}{l}\text { tidak } \\
\text { d isebutkan }\end{array}$ & lain-lain & $\begin{array}{l}\text { analisis } \\
\text { kartografi }\end{array}$ & $\begin{array}{l}\text { tidak sinkron } \\
\text { dengan } \\
\text { masalah }\end{array}$ & tepat \\
\hline 12 & 1997 & $\begin{array}{l}\text { Ekskavasi } \\
\text { Arkeologi di } \\
\text { Kawasan } \\
\text { Jalur Hijau } \\
\text { Jalan Kapten } \\
\text { Pierre } \\
\text { Tendean }\end{array}$ & $\begin{array}{l}\text { tidak } \\
\text { disebutkan }\end{array}$ & $\begin{array}{l}\text { tidak } \\
\text { disebutkan }\end{array}$ & $\begin{array}{l}\text { tidak } \\
\text { disebutkan }\end{array}$ & ekskavasi & $\begin{array}{l}\text { analisis } \\
\text { artefaktual }\end{array}$ & $\begin{array}{l}\text { data dapat } \\
\text { dijela skan }\end{array}$ & $\begin{array}{l}\text { tidak dapat } \\
\text { dijelaskan }\end{array}$ \\
\hline
\end{tabular}




\begin{tabular}{|c|c|c|c|c|c|c|c|c|c|}
\hline \multirow[t]{2}{*}{ No } & \multirow[t]{2}{*}{ Tahun } & \multirow[t]{2}{*}{ Judul } & \multirow[t]{2}{*}{ Permasalahan } & \multicolumn{4}{|c|}{ Metode Penelitian } & \multirow[t]{2}{*}{ Kes impulan } & \multirow[t]{2}{*}{ Ket } \\
\hline & & & & Sifat & Penalaran & $\begin{array}{c}\text { Pengumpulan } \\
\text { Data }\end{array}$ & $\begin{array}{l}\text { Me tode } \\
\text { Analis is }\end{array}$ & & \\
\hline 13 & 1997 & $\begin{array}{l}\text { Penelitian } \\
\text { Permukiman } \\
\text { Kuna Situs } \\
\text { Pulang Pisau, } \\
\text { di Kahayan } \\
\text { Hilir, Kapuas, } \\
\text { Kalimantan } \\
\text { Tengah } \\
\end{array}$ & $\begin{array}{l}\text { tidak } \\
\text { disebutkan }\end{array}$ & $\begin{array}{l}\text { tidak } \\
\text { disebutkan }\end{array}$ & $\begin{array}{l}\text { tidak } \\
\text { disebutkan }\end{array}$ & $\begin{array}{l}\text { survei- } \\
\text { ekska vasi- } \\
\text { wawan cara }\end{array}$ & $\begin{array}{l}\text { a nalisis } \\
\text { artefaktual; } \\
\text { a nalisis } \\
\text { kontekstual; } \\
\text { analisis } \\
\text { lingkungan; } \\
\text { a nalisis } \\
\text { pertang galan }\end{array}$ & $\begin{array}{l}\text { data dapat } \\
\text { dijelaskan }\end{array}$ & $\begin{array}{l}\text { tidak dapat } \\
\text { dije laskan }\end{array}$ \\
\hline 14 & 1997 & $\begin{array}{l}\text { Pemetaan } \\
\text { Situs Pulang } \\
\text { Pisau } \\
\text { Kabupaten } \\
\text { Kapuas, } \\
\text { Kalimantan } \\
\text { Tengah }\end{array}$ & $\begin{array}{l}\text { apa bentuk } \\
\text { data; } \\
\text { bagaimana } \\
\text { kond isi } \\
\text { lingkungannya }\end{array}$ & $\begin{array}{l}\text { tidak } \\
\text { d isebutkan }\end{array}$ & $\begin{array}{l}\text { tidak } \\
\text { disebutkan }\end{array}$ & survei & $\begin{array}{l}\text { tidak } \\
\text { disebutkan }\end{array}$ & $\begin{array}{l}\text { tidak sinkron } \\
\text { dengan } \\
\text { masalah }\end{array}$ & tepat \\
\hline 15 & 1998 & $\begin{array}{l}\text { Penelitian } \\
\text { Situs Gua Babi } \\
\text { Tahap III dan } \\
\text { IV Kecamatan } \\
\text { Muara Uya, } \\
\text { Kabupaten } \\
\text { Tabalong, } \\
\text { Kalimantan } \\
\text { Selatan }\end{array}$ & $\begin{array}{l}\text { siapa manusia; } \\
\text { bagaimana } \\
\text { hunian guanya } \\
\text { dan tingkatan } \\
\text { budayanya }\end{array}$ & deskriptif & ind uktif & ekskavasi & $\begin{array}{l}\text { a nalisis } \\
\text { a rtefaktual; } \\
\text { ikonografi; } \\
\text { historis }\end{array}$ & $\begin{array}{l}\text { perma salahan } \\
\text { te rjawab }\end{array}$ & tepat \\
\hline 16 & 1998 & $\begin{array}{l}\text { Pemetaan } \\
\text { Situs Gua } \\
\text { Babi, De sa } \\
\text { Randu, } \\
\text { Kecamatan } \\
\text { Muara Uya, } \\
\text { Kabupaten } \\
\text { Tabalong, } \\
\text { Kalimantan } \\
\text { Selatan }\end{array}$ & $\begin{array}{l}\text { tidak } \\
\text { disebutkan }\end{array}$ & $\begin{array}{l}\text { tidak } \\
\text { disebutkan }\end{array}$ & $\begin{array}{l}\text { tidak } \\
\text { disebutkan }\end{array}$ & lain-lain & pemetaan & $\begin{array}{l}\text { tidak } \\
\text { teridentifikasi }\end{array}$ & $\begin{array}{l}\text { tidak dapat } \\
\text { dijelaskan }\end{array}$ \\
\hline 17 & 1998 & $\begin{array}{l}\text { Penelitian } \\
\text { Situs Candi } \\
\text { Laras Tahap III } \\
\text { Kabupaten } \\
\text { Tapin, } \\
\text { Kalimantan } \\
\text { Selatan }\end{array}$ & $\begin{array}{l}\text { a pa bentuk } \\
\text { arsitektur } \\
\text { bangunan; apa } \\
\text { fungsi; kapan } \\
\text { kronologi; } \\
\text { bagaimana pola } \\
\text { pemukiman }\end{array}$ & deskriptif & ind uktif & $\begin{array}{l}\text { survei- } \\
\text { ekskavasi }\end{array}$ & $\begin{array}{l}\text { analisis } \\
\text { artefaktual; } \\
\text { a nalisis } \\
\text { stratigrafi }\end{array}$ & $\begin{array}{l}\text { perma salahan } \\
\text { belum } \\
\text { te rjawab }\end{array}$ & tepat \\
\hline 18 & 1998 & $\begin{array}{l}\text { Laporan } \\
\text { Kegiatan } \\
\text { Ekskavasi } \\
\text { Penyelamatan } \\
\text { Sisa Kapal } \\
\text { Masa } \\
\text { Pemerin tahan } \\
\text { Hindia Belanda } \\
\text { di Bantaran } \\
\text { Sungai } \\
\text { Martapura, } \\
\text { Jalan Kapten } \\
\text { Pierre } \\
\text { Tendean, } \\
\text { Sungai Mesa, } \\
\text { Banjarmasin, } \\
\text { Kalimantan } \\
\text { Selatan }\end{array}$ & $\begin{array}{l}\text { tidak } \\
\text { disebutkan }\end{array}$ & $\begin{array}{l}\text { tidak } \\
\text { disebutkan }\end{array}$ & $\begin{array}{l}\text { tidak } \\
\text { disebutkan }\end{array}$ & ekskavasi & $\begin{array}{l}\text { a nalisis } \\
\text { a rtefaktual }\end{array}$ & $\begin{array}{l}\text { data dapat } \\
\text { dijelaskan }\end{array}$ & $\begin{array}{l}\text { tidak dapat } \\
\text { dije laskan }\end{array}$ \\
\hline
\end{tabular}




\begin{tabular}{|c|c|c|c|c|c|c|c|c|c|}
\hline \multirow[t]{2}{*}{ No } & \multirow[t]{2}{*}{ Tahun } & \multirow[t]{2}{*}{ Judul } & \multirow[t]{2}{*}{ Permasalahan } & \multicolumn{4}{|c|}{ Metode Penelitian } & \multirow[t]{2}{*}{ Kes impulan } & \multirow[t]{2}{*}{ Ket } \\
\hline & & & & Sifat & Pe nalaran & $\begin{array}{c}\text { Pengumpulan } \\
\text { Data }\end{array}$ & $\begin{array}{l}\text { Me tode } \\
\text { Analis is }\end{array}$ & & \\
\hline 19 & 1998 & $\begin{array}{l}\text { Peninjauan di } \\
\text { Situs Sungai } \\
\text { Pasah } \\
\text { Kecamatan } \\
\text { Hilir, } \\
\text { Kabupaten } \\
\text { Kapuas, } \\
\text { Kalimantan } \\
\text { Tengah }\end{array}$ & $\begin{array}{l}\text { di ma na lo kasi; } \\
\text { apa bentuk } \\
\text { data; } \\
\text { bagaimana } \\
\text { kond isi } \\
\text { lingkungan }\end{array}$ & deskriptif & ind uktif & $\begin{array}{l}\text { survei- } \\
\text { wawancara }\end{array}$ & $\begin{array}{l}\text { analisis } \\
\text { paleontologi }\end{array}$ & $\begin{array}{l}\text { perma salahan } \\
\text { belum } \\
\text { te rjawab }\end{array}$ & tepat \\
\hline 20 & 1998 & $\begin{array}{l}\text { Peninjauan di } \\
\text { Situs Ulu } \\
\text { Benteng } \\
\text { Kecamatan } \\
\text { Marabahan } \\
\text { Kota, } \\
\text { Kabupaten } \\
\text { Batola, } \\
\text { Kalimantan } \\
\text { Selatan } \\
\end{array}$ & $\begin{array}{l}\text { tidak } \\
\text { disebutkan }\end{array}$ & deskriptif & ind uktif & survei & $\begin{array}{l}\text { tidak } \\
\text { disebutkan }\end{array}$ & $\begin{array}{l}\text { data dapat } \\
\text { dijelaskan }\end{array}$ & $\begin{array}{l}\text { tidak dapat } \\
\text { dijelaskan }\end{array}$ \\
\hline 21 & 1999 & $\begin{array}{l}\text { Penelitian } \\
\text { Situs Gua } \\
\text { Babi: } \\
\text { Mekanisme } \\
\text { Budaya } \\
\text { Hunian Gua } \\
\text { Prasejarah } \\
\text { dalam Skala } \\
\text { Semi Makro di } \\
\text { Kawa san } \\
\text { Gunung } \\
\text { Batubuli } \\
\end{array}$ & $\begin{array}{l}\text { siapa man usia; } \\
\text { bagaimana pola } \\
\text { adaptasi dan } \\
\text { interaksi } \\
\text { antarkomunitas }\end{array}$ & $\begin{array}{l}\text { eksploratif- } \\
\text { deskriptif }\end{array}$ & ind uktif & $\begin{array}{l}\text { survei- } \\
\text { ekskavasi }\end{array}$ & $\begin{array}{l}\text { analisis } \\
\text { artefaktual }\end{array}$ & $\begin{array}{l}\text { permasalahan } \\
\text { te rjawab }\end{array}$ & $\begin{array}{l}\text { gabungan } \\
\text { eksp loratif- } \\
\text { deskriptif }\end{array}$ \\
\hline 22 & 1999 & $\begin{array}{l}\text { Penelitian } \\
\text { Situs Candi } \\
\text { Laras Tahap } \\
\text { IV Kabupaten } \\
\text { Tapin, } \\
\text { Kalimantan } \\
\text { Selatan }\end{array}$ & $\begin{array}{l}\text { apa } \\
\text { karakte ristik } \\
\text { situs; kapan } \\
\text { difungsikan }\end{array}$ & deskriptif & ind uktif & $\begin{array}{l}\text { survei- } \\
\text { ekskavasi }\end{array}$ & $\begin{array}{l}\text { analisis } \\
\text { tipologi; } \\
\text { kontekstual }\end{array}$ & $\begin{array}{l}\text { permasalahan } \\
\text { te rjawab }\end{array}$ & tepat \\
\hline 23 & 1999 & $\begin{array}{l}\text { Pertanggalan } \\
\text { Radiokarbon } \\
\text { Situs } \\
\text { Pematang } \\
\text { Bata, Candi } \\
\text { Laras } \\
\text { Kabupaten } \\
\text { Tapin, } \\
\text { Kalimantan } \\
\text { Selatan }\end{array}$ & $\begin{array}{l}\text { kapan masa } \\
\text { situs } \\
\text { berlangsung }\end{array}$ & deskriptif & ind uktif & ekskavasi & $\begin{array}{l}\text { analisis } \\
\text { pertanggalan }\end{array}$ & $\begin{array}{l}\text { perma salahan } \\
\text { te jjawab }\end{array}$ & tepat \\
\hline 24 & 1999 & $\begin{array}{l}\text { Penelitian } \\
\text { Arsitektur } \\
\text { Makam Raja- } \\
\text { raja di Wilayah } \\
\text { Kalimantan } \\
\text { Timur I, } \\
\text { Kabupaten } \\
\text { Kutai }\end{array}$ & $\begin{array}{l}\text { tidak } \\
\text { disebutkan }\end{array}$ & deskriptif & induktif & survei & $\begin{array}{l}\text { analisis } \\
\text { arsitektur; } \\
\text { analisis } \\
\text { stilistik }\end{array}$ & $\begin{array}{l}\text { data dapat } \\
\text { dijelaskan }\end{array}$ & tepat \\
\hline
\end{tabular}




\begin{tabular}{|c|c|c|c|c|c|c|c|c|c|}
\hline \multirow[t]{2}{*}{ No } & \multirow[t]{2}{*}{ Tahun } & \multirow[t]{2}{*}{ Judul } & \multirow[t]{2}{*}{ Permasalahan } & \multicolumn{4}{|c|}{ Metode Penelitian } & \multirow[t]{2}{*}{ Kes impulan } & \multirow[t]{2}{*}{ Ket } \\
\hline & & & & Sifat & Penalaran & $\begin{array}{c}\text { Pengumpulan } \\
\text { Data }\end{array}$ & $\begin{array}{l}\text { Me tode } \\
\text { Analis is }\end{array}$ & & \\
\hline 25 & 1999 & $\begin{array}{l}\text { Ekskavasi } \\
\text { Situs benteng } \\
\text { Tabanio Tah ap } \\
\text { III Kabu paten } \\
\text { Tanah Laut, } \\
\text { Kalimantan } \\
\text { Selatan }\end{array}$ & $\begin{array}{l}\text { apa denah } \\
\text { benteng }\end{array}$ & deskriptif & ind uktif & ekskavasi & $\begin{array}{l}\text { analisis } \\
\text { artefaktual; } \\
\text { analisis } \\
\text { arsitektural }\end{array}$ & $\begin{array}{l}\text { permasalahan } \\
\text { te rjawab }\end{array}$ & tepat \\
\hline 26 & 1999 & $\begin{array}{l}\text { Penelitian } \\
\text { Etnoarke ologi } \\
\text { Tradisi } \\
\text { Pembuatan } \\
\text { Gerabah } \\
\text { Nagara, Hulu } \\
\text { Sungai } \\
\text { Selatan, } \\
\text { Kalimantan } \\
\text { Selatan }\end{array}$ & $\begin{array}{l}\text { bagaimana } \\
\text { kesinambungan } \\
\text { teknologi } \\
\text { gerabah; apa } \\
\text { faktor yang } \\
\text { mela tarbelakan } \\
\text { ginya }\end{array}$ & deskriptif & induktif & wawan cara & $\begin{array}{l}\text { etnoarkeologi } \\
\text {; analisis } \\
\text { komparatif }\end{array}$ & $\begin{array}{l}\text { pema salahan } \\
\text { te rjawab }\end{array}$ & tepat \\
\hline 27 & 2000 & $\begin{array}{l}\text { Pertanggalan } \\
\text { Radio Carbon } \\
\text { Situs Candi } \\
\text { Laras } \\
\text { Kabupaten } \\
\text { Tapin, } \\
\text { Kalimantan } \\
\text { Selatan }\end{array}$ & $\begin{array}{l}\text { kapan masa } \\
\text { situs } \\
\text { berlangsung }\end{array}$ & deskriptif & ind uktif & ekskavasi & $\begin{array}{l}\text { analisis } \\
\text { pertanggalan; } \\
\text { analisis } \\
\text { stratigrafi }\end{array}$ & $\begin{array}{l}\text { perma salahan } \\
\text { terjawab }\end{array}$ & tepat \\
\hline 28 & 2000 & $\begin{array}{l}\text { Umur Candi } \\
\text { Laras dalam } \\
\text { Panggung } \\
\text { Sejarah Kuna } \\
\text { Indonesia }\end{array}$ & $\begin{array}{l}\text { kapan situs } \\
\text { diban gun; } \\
\text { bagaimana } \\
\text { kedudukan } \\
\text { situs dalam } \\
\text { sejarah } \\
\text { Indonesia }\end{array}$ & deskriptif & ind uktif & ekskavasi & $\begin{array}{l}\text { analisis } \\
\text { pertanggalan }\end{array}$ & $\begin{array}{l}\text { perma salahan } \\
\text { belum } \\
\text { te rjawab }\end{array}$ & tepat \\
\hline 29 & 2000 & $\begin{array}{l}\text { Penelitian } \\
\text { Pemukiman } \\
\text { Situs Harigen, } \\
\text { Kalimanatan } \\
\text { Tengah }\end{array}$ & $\begin{array}{l}\text { apa karakter } \\
\text { situs; } \\
\text { bagaimana } \\
\text { sistem } \\
\text { penguburan }\end{array}$ & $\begin{array}{l}\text { tidak } \\
\text { disebutkan }\end{array}$ & $\begin{array}{l}\text { tidak } \\
\text { disebutkan }\end{array}$ & $\begin{array}{l}\text { survei- } \\
\text { wawancara }\end{array}$ & $\begin{array}{l}\text { tidak } \\
\text { disebutkan }\end{array}$ & $\begin{array}{l}\text { pemasalahan } \\
\text { terjawab }\end{array}$ & $\begin{array}{l}\text { tidak dapat } \\
\text { dije laskan }\end{array}$ \\
\hline 30 & 2000 & $\begin{array}{l}\text { Penelitian } \\
\text { Arsitektur } \\
\text { Makam Raja- } \\
\text { raja di wilayah } \\
\text { Kalimantan } \\
\text { Timur II, } \\
\text { Kabupaten } \\
\text { Berau dan } \\
\text { Bulungan }\end{array}$ & $\begin{array}{l}\text { apa bentuk } \\
\text { arsitektur; } \\
\text { bagaimana } \\
\text { perkembang an } \\
\text { dan perbedaan } \\
\text { tata le tak } \\
\text { makam } \\
\text { berdasarkan } \\
\text { stratifikasi } \\
\text { sosial }\end{array}$ & deskriptif & ind uktif & $\begin{array}{l}\text { survei- } \\
\text { wawancara }\end{array}$ & $\begin{array}{l}\text { analisis } \\
\text { arsitektur; } \\
\text { analisis } \\
\text { stilistik }\end{array}$ & $\begin{array}{l}\text { perma salahan } \\
\text { belum } \\
\text { terjawab }\end{array}$ & tepat \\
\hline
\end{tabular}




\begin{tabular}{|c|c|c|c|c|c|c|c|c|c|}
\hline \multirow[t]{2}{*}{ No } & \multirow[t]{2}{*}{ Tahun } & \multirow[t]{2}{*}{ Judul } & \multirow[t]{2}{*}{ Permasalahan } & \multicolumn{4}{|c|}{ Metode Penelitian } & \multirow[t]{2}{*}{ Kes impulan } & \multirow[t]{2}{*}{ Ket } \\
\hline & & & & Sifat & Penalaran & $\begin{array}{c}\text { Pengumpulan } \\
\text { Data }\end{array}$ & $\begin{array}{l}\text { Me tode } \\
\text { Analis is }\end{array}$ & & \\
\hline 31 & 2001 & $\begin{array}{l}\text { Penelitian } \\
\text { Arsitektur } \\
\text { Makam Raja- } \\
\text { raja di } \\
\text { Kabupaten } \\
\text { Pasir }\end{array}$ & $\begin{array}{l}\text { a pa bentuk } \\
\text { arsitektur; } \\
\text { bagaimana } \\
\text { perkembangan } \\
\text { dan perbedaan } \\
\text { tata letak } \\
\text { makam } \\
\text { berdasarkan } \\
\text { stratifikasi } \\
\text { sosial }\end{array}$ & deskriptif & induktif & $\begin{array}{l}\text { survei- } \\
\text { wawancara }\end{array}$ & $\begin{array}{l}\text { analisis } \\
\text { arsitektur; } \\
\text { analisis } \\
\text { stilistik }\end{array}$ & $\begin{array}{l}\text { permasalahan } \\
\text { belum } \\
\text { terjawab }\end{array}$ & tepat \\
\hline 32 & 2001 & $\begin{array}{l}\text { Studi Epigrafi } \\
\text { dan Naskah } \\
\text { Islamologi di } \\
\text { Kabupaten } \\
\text { Kutai, } \\
\text { Kalimantan } \\
\text { Timur }\end{array}$ & $\begin{array}{l}\text { apa langgam } \\
\text { naskah; } \\
\text { bagaimana } \\
\text { persebarannya; } \\
\text { bagaimana } \\
\text { proses } \\
\text { masuknya } \\
\text { Islam } \\
\end{array}$ & deskriptif & induktif & $\begin{array}{l}\text { survei-studi } \\
\text { pustaka }\end{array}$ & $\begin{array}{l}\text { analisis } \\
\text { naskah }\end{array}$ & $\begin{array}{l}\text { permasalahan } \\
\text { belum } \\
\text { terjawab }\end{array}$ & tepat \\
\hline 33 & 2001 & $\begin{array}{l}\text { Survai Konsep } \\
\text { dan Bentuk } \\
\text { Bangunan } \\
\text { Kubur } \\
\text { Masyarakat } \\
\text { dayak di } \\
\text { Kecamatan } \\
\text { Tanta, Upau, } \\
\text { dan Muara } \\
\text { Uya, } \\
\text { Kabupaten } \\
\text { Tabalong, } \\
\text { Kalimantan } \\
\text { Selatan }\end{array}$ & $\begin{array}{l}\text { apa bentuk } \\
\text { bangunan } \\
\text { kubur; } \\
\text { bagaimana } \\
\text { konsepnya; } \\
\text { bagaimana } \\
\text { kesin ambungan } \\
\text { budayanya }\end{array}$ & $\begin{array}{l}\text { deskriptif- } \\
\text { komparatif }\end{array}$ & induktif & $\begin{array}{l}\text { Survei- } \\
\text { wawancara }\end{array}$ & $\begin{array}{l}\text { tidak } \\
\text { disebutkan }\end{array}$ & $\begin{array}{l}\text { permasalahan } \\
\text { te rjawab }\end{array}$ & tepat \\
\hline 34 & 2001 & $\begin{array}{l}\text { Sistem } \\
\text { Penguburan } \\
\text { Masyarakat } \\
\text { Pendukung } \\
\text { Budaya Paju } \\
\text { Sepuluh di } \\
\text { Desa } \\
\text { Haringen, } \\
\text { Kabupaten } \\
\text { Barito Selatan, } \\
\text { Kalimantan } \\
\text { Tengah } \\
\end{array}$ & $\begin{array}{l}\text { apa komponen } \\
\text { ritual kubur; } \\
\text { bagaimana } \\
\text { sistem } \\
\text { penguburan }\end{array}$ & deskriptif & induktif & $\begin{array}{l}\text { Survei- } \\
\text { ekskavasi- } \\
\text { wawancara }\end{array}$ & $\begin{array}{l}\text { tidak } \\
\text { disebutkan }\end{array}$ & $\begin{array}{l}\text { perma salahan } \\
\text { terjawab }\end{array}$ & tepat \\
\hline 35 & 2001 & $\begin{array}{l}\text { Konsep } \\
\text { Kematian dan } \\
\text { Penguburan } \\
\text { Masyarakat } \\
\text { Dayak } \\
\text { Lawangan di } \\
\text { Desa } \\
\text { Dambung } \\
\text { Raya, } \\
\text { Kecamatan } \\
\text { Haruai, } \\
\text { Kabupaten } \\
\text { Tabalong }\end{array}$ & $\begin{array}{l}\text { bagaimana } \\
\text { karakter situs; } \\
\text { bagaimana } \\
\text { sistem } \\
\text { penguburan } \\
\text { masyarakat } \\
\text { pendukungnya }\end{array}$ & $\begin{array}{l}\text { deskriptif- } \\
\text { komp aratif }\end{array}$ & induktif & wawan cara & $\begin{array}{l}\text { tidak } \\
\text { disebutkan }\end{array}$ & $\begin{array}{l}\text { tidak sinkron } \\
\text { dengan } \\
\text { masalah }\end{array}$ & tepat \\
\hline 36 & 2002 & $\begin{array}{l}\text { Penelitian } \\
\text { Arsitektur } \\
\text { Makam Raja- } \\
\text { raja di } \\
\text { Kabupaten } \\
\text { Kotabaru } \\
\text { Kalimantan } \\
\text { Selatan }\end{array}$ & $\begin{array}{l}\text { apa bentuk } \\
\text { aristektur; } \\
\text { bagaimana } \\
\text { perkembangan } \\
\text { dan perbedaan } \\
\text { tata letak } \\
\text { berdasarkan } \\
\text { stratifikasi } \\
\text { sosial }\end{array}$ & deskriptif & induktif & $\begin{array}{l}\text { survei- } \\
\text { wawancara }\end{array}$ & $\begin{array}{l}\text { analisis } \\
\text { arsitektur; } \\
\text { analisis } \\
\text { stilistik }\end{array}$ & $\begin{array}{l}\text { perma salahan } \\
\text { belum } \\
\text { terjawab }\end{array}$ & tepat \\
\hline
\end{tabular}




\begin{tabular}{|c|c|c|c|c|c|c|c|c|c|}
\hline \multirow[t]{2}{*}{ No } & \multirow[t]{2}{*}{ Tahun } & \multirow[t]{2}{*}{ Judul } & \multirow[t]{2}{*}{ Permasalahan } & \multicolumn{4}{|c|}{ Metode Penelitian } & \multirow[t]{2}{*}{ Kesimpulan } & \multirow[t]{2}{*}{ Ket } \\
\hline & & & & Sifat & Penalaran & $\begin{array}{c}\text { Pengumpulan } \\
\text { Data }\end{array}$ & $\begin{array}{l}\text { Me tode } \\
\text { Analis is }\end{array}$ & & \\
\hline 37 & 2002 & $\begin{array}{l}\text { Ekskavasi } \\
\text { Situs Kubur } \\
\text { Masyarakat } \\
\text { Kaharingan } \\
\text { Pendukung } \\
\text { Budaya Paju } \\
\text { Sepuluh Awal } \\
\text { di Situs } \\
\text { Haringen dan } \\
\text { Magantis, } \\
\text { Kecamatan } \\
\text { Dusun Timur, } \\
\text { Kab. Barito } \\
\text { Timur, } \\
\text { Kalimantan } \\
\text { Tengah }\end{array}$ & $\begin{array}{l}\text { apa bentuk } \\
\text { data; } \\
\text { bagaimana } \\
\text { denah } \\
\text { lokasinya }\end{array}$ & $\begin{array}{l}\text { tidak } \\
\text { disebutkan }\end{array}$ & $\begin{array}{l}\text { tidak } \\
\text { disebu tkan }\end{array}$ & $\begin{array}{l}\text { survei- } \\
\text { ekska vasi- } \\
\text { wawan cara }\end{array}$ & $\begin{array}{l}\text { tidak } \\
\text { disebutkan }\end{array}$ & $\begin{array}{l}\text { perma salahan } \\
\text { terjawab }\end{array}$ & tepat \\
\hline 38 & 2002 & $\begin{array}{l}\text { Studi } \\
\text { Etnografis } \\
\text { Upacara } \\
\text { Masyarakat } \\
\text { Dayak Ngaju } \\
\text { Kelurahan } \\
\text { Pendahara, } \\
\text { Kalimantan } \\
\text { Tengah }\end{array}$ & $\begin{array}{l}\text { bagaimana } \\
\text { konsep } \\
\text { kematian; apa } \\
\text { makna upacara; } \\
\text { bagaimana } \\
\text { kesinambungan } \\
\text { budayanya }\end{array}$ & $\begin{array}{l}\text { tidak } \\
\text { d isebutkan }\end{array}$ & $\begin{array}{l}\text { tidak } \\
\text { disebu tkan }\end{array}$ & $\begin{array}{l}\text { survei- } \\
\text { wawan cara }\end{array}$ & $\begin{array}{l}\text { tidak } \\
\text { disebutkan }\end{array}$ & $\begin{array}{l}\text { perma salahan } \\
\text { belum } \\
\text { terjawab }\end{array}$ & tepat \\
\hline 39 & 2002 & $\begin{array}{l}\text { Penelitian } \\
\text { Etnoarke ologi } \\
\text { Bangunan } \\
\text { Kubur Suku } \\
\text { Dayak Ngaju di } \\
\text { Kecamatan } \\
\text { Parenggean } \\
\text { dan Mentaya } \\
\text { Hulu } \\
\text { Kabupaten } \\
\text { Kotawaringin } \\
\text { Timu r, } \\
\text { Kalimantan } \\
\text { Tengah }\end{array}$ & $\begin{array}{l}\text { apa variasi } \\
\text { bentuk kubur; } \\
\text { bagaimana } \\
\text { kesinambungan } \\
\text { budayanya }\end{array}$ & $\begin{array}{l}\text { tidak } \\
\text { disebutkan }\end{array}$ & $\begin{array}{l}\text { tidak } \\
\text { disebu tkan }\end{array}$ & $\begin{array}{l}\text { survei- } \\
\text { wawan cara }\end{array}$ & $\begin{array}{l}\text { tidak } \\
\text { disebutkan }\end{array}$ & $\begin{array}{l}\text { perma salahan } \\
\text { belum } \\
\text { terjawab }\end{array}$ & tepat \\
\hline 40 & 2003 & $\begin{array}{l}\text { Studi Epigrafi } \\
\text { dan Naskah } \\
\text { Islamologi di } \\
\text { Kabupaten } \\
\text { Pasir, } \\
\text { Kalimantan } \\
\text { Timur }\end{array}$ & $\begin{array}{l}\text { bagaimana } \\
\text { proses } \\
\text { masuknya } \\
\text { Islam dan } \\
\text { perubahan } \\
\text { budaya }\end{array}$ & deskriptif & induktif & $\begin{array}{l}\text { survei-studi } \\
\text { pustaka }\end{array}$ & $\begin{array}{l}\text { analisis } \\
\text { naskah }\end{array}$ & $\begin{array}{l}\text { perma salahan } \\
\text { belum } \\
\text { terjawab }\end{array}$ & tepat \\
\hline 41 & 2003 & $\begin{array}{l}\text { Arkeologi } \\
\text { Sejarah Kota } \\
\text { Tarakan }\end{array}$ & $\begin{array}{l}\text { apa potensi } \\
\text { data }\end{array}$ & $\begin{array}{l}\text { eksploratif- } \\
\text { deskriptif }\end{array}$ & induktif & $\begin{array}{l}\text { survei- } \\
\text { ekskavasi }\end{array}$ & $\begin{array}{l}\text { analisis } \\
\text { artefaktual; } \\
\text { analisis ruang }\end{array}$ & $\begin{array}{l}\text { perma salahan } \\
\text { terjawab }\end{array}$ & $\begin{array}{l}\text { gabungan } \\
\text { eksp loratif- } \\
\text { deskriptif }\end{array}$ \\
\hline 42 & 2003 & $\begin{array}{l}\text { Penelitian } \\
\text { Etnoarke ologi } \\
\text { Religi Suku } \\
\text { Da yak Benuaq } \\
\text { di Kecamatan } \\
\text { Jempang dan } \\
\text { Damai, } \\
\text { Kabupaten } \\
\text { Kutai Barat, } \\
\text { Kalimantan } \\
\text { Timur } \\
\end{array}$ & $\begin{array}{l}\text { apa variasi } \\
\text { bentuk kubur; } \\
\text { bagaimana } \\
\text { sistem religinya }\end{array}$ & $\begin{array}{l}\text { tidak } \\
\text { disebutkan }\end{array}$ & $\begin{array}{l}\text { tidak } \\
\text { disebu tkan }\end{array}$ & $\begin{array}{l}\text { survei- } \\
\text { wawan cara }\end{array}$ & $\begin{array}{l}\text { tidak } \\
\text { disebutkan }\end{array}$ & $\begin{array}{l}\text { perma salahan } \\
\text { terjawab }\end{array}$ & tepat \\
\hline
\end{tabular}




\begin{tabular}{|c|c|c|c|c|c|c|c|c|c|}
\hline \multirow[t]{2}{*}{ No } & \multirow[t]{2}{*}{ Tahun } & \multirow[t]{2}{*}{ Judul } & \multirow[t]{2}{*}{ Permasalahan } & \multicolumn{4}{|c|}{ Metode Penelitian } & \multirow[t]{2}{*}{ Kes impulan } & \multirow[t]{2}{*}{ Ket } \\
\hline & & & & Sifat & Penalaran & $\begin{array}{c}\text { Pengumpulan } \\
\text { Data }\end{array}$ & $\begin{array}{l}\text { Me tode } \\
\text { Analis is }\end{array}$ & & \\
\hline 43 & 2003 & $\begin{array}{l}\text { Tradisi } \\
\text { Upacara } \\
\text { Marabia pada } \\
\text { Masyarakat } \\
\text { Kaharingan di } \\
\text { Desa Hayapin, } \\
\text { Kecamatan } \\
\text { Awang, } \\
\text { Kabupaten } \\
\text { Barito Timur, } \\
\text { Kalimantan } \\
\text { Tengah }\end{array}$ & $\begin{array}{l}\text { bagaimana cara } \\
\text { dan pro sesnya; } \\
\text { bagaimana } \\
\text { kesinambungan } \\
\text { budayanya }\end{array}$ & deskriptif & induktif & $\begin{array}{l}\text { survei- } \\
\text { wawancara }\end{array}$ & $\begin{array}{l}\text { tidak } \\
\text { disebutkan }\end{array}$ & $\begin{array}{l}\text { permasalahan } \\
\text { terjawab }\end{array}$ & tepat \\
\hline 44 & 2004 & $\begin{array}{l}\text { Penelitian } \\
\text { Situs Candi } \\
\text { Agung } \\
\text { Kabupaten } \\
\text { Hulu Sungai } \\
\text { Utara } \\
\text { Kalimantan } \\
\text { Selatan }\end{array}$ & $\begin{array}{l}\text { bagaimana } \\
\text { kaitan fungsi } \\
\text { candi dengan } \\
\text { keberadaan } \\
\text { sungai }\end{array}$ & deskriptif & induktif & ekskavasi & $\begin{array}{l}\text { analisis } \\
\text { artefaktual }\end{array}$ & $\begin{array}{l}\text { permasalahan } \\
\text { b elum } \\
\text { terjawab }\end{array}$ & tepat \\
\hline 45 & 2004 & $\begin{array}{l}\text { Penelitian Tata } \\
\text { kota Kuna } \\
\text { Tenggarong } \\
\text { dan Paser } \\
\text { Balengkong } \\
\text { Kalimantan } \\
\text { Timur }\end{array}$ & $\begin{array}{l}\text { apa bentuk tata } \\
\text { kota kuna }\end{array}$ & deskriptif & induktif & $\begin{array}{l}\text { survei- } \\
\text { wawancara }\end{array}$ & $\begin{array}{l}\text { tidak } \\
\text { disebutkan }\end{array}$ & $\begin{array}{l}\text { permasalahan } \\
\text { terjawab }\end{array}$ & tepat \\
\hline 46 & 2004 & $\begin{array}{l}\text { Melacak Sisa- } \\
\text { sisa Kerajaan } \\
\text { Banjar di } \\
\text { Kawasan Ku in } \\
\text { dan Kawasan } \\
\text { Kayu Tangi } \\
\text { Kalimantan } \\
\text { Selatan }\end{array}$ & $\begin{array}{l}\text { tidak } \\
\text { disebutkan }\end{array}$ & $\begin{array}{l}\text { tidak } \\
\text { disebutkan }\end{array}$ & $\begin{array}{l}\text { tidak } \\
\text { disebutkan }\end{array}$ & $\begin{array}{l}\text { survei- } \\
\text { ekskavasi }\end{array}$ & $\begin{array}{l}\text { analisis } \\
\text { artefaktual; } \\
\text { analisis } \\
\text { to ponimi }\end{array}$ & $\begin{array}{l}\text { data dapat } \\
\text { d jielaskan }\end{array}$ & $\begin{array}{l}\text { tidak dapat } \\
\text { dije laskan }\end{array}$ \\
\hline 47 & 2004 & $\begin{array}{l}\text { Penelitian Pola } \\
\text { Keruangan } \\
\text { Tata Kota } \\
\text { Teluk bayur } \\
\text { Kota Kolonial } \\
\text { di Kabupaten } \\
\text { Berau, } \\
\text { Kalimantan } \\
\text { Timur }\end{array}$ & $\begin{array}{l}\text { tidak } \\
\text { disebutkan }\end{array}$ & $\begin{array}{l}\text { tidak } \\
\text { disebutkan }\end{array}$ & $\begin{array}{l}\text { tidak } \\
\text { disebutkan }\end{array}$ & $\begin{array}{l}\text { survei- } \\
\text { wawancara }\end{array}$ & $\begin{array}{l}\text { tidak } \\
\text { disebutkan }\end{array}$ & $\begin{array}{l}\text { data dapat } \\
\text { dijelaskan }\end{array}$ & $\begin{array}{l}\text { tidak dapat } \\
\text { dije laskan }\end{array}$ \\
\hline 48 & 2004 & $\begin{array}{l}\text { Lapo ran } \\
\text { Peninjauan } \\
\text { Penemuan } \\
\text { Meriam di } \\
\text { Martapura }\end{array}$ & $\begin{array}{l}\text { tidak } \\
\text { disebutkan }\end{array}$ & $\begin{array}{l}\text { tidak } \\
\text { disebutkan }\end{array}$ & $\begin{array}{l}\text { tidak } \\
\text { disebutkan }\end{array}$ & $\begin{array}{l}\text { tidak } \\
\text { d isebutkan }\end{array}$ & $\begin{array}{l}\text { tidak } \\
\text { disebutkan }\end{array}$ & $\begin{array}{l}\text { data dapat } \\
\text { dijelaskan }\end{array}$ & $\begin{array}{l}\text { tidak dapat } \\
\text { dije laskan }\end{array}$ \\
\hline 49 & 2004 & $\begin{array}{l}\text { Penelitian dan } \\
\text { Ekskavasi } \\
\text { Permukiman } \\
\text { Kolonial di } \\
\text { Kecamatan } \\
\text { Kurau, } \\
\text { Kabupaten } \\
\text { Tanah Laut, } \\
\text { Kalimantan } \\
\text { Selatan }\end{array}$ & $\begin{array}{l}\text { tidak } \\
\text { disebutkan }\end{array}$ & $\begin{array}{l}\text { tidak } \\
\text { disebutkan }\end{array}$ & $\begin{array}{l}\text { tidak } \\
\text { disebutkan }\end{array}$ & ekskavasi & $\begin{array}{l}\text { tidak } \\
\text { disebutkan }\end{array}$ & $\begin{array}{l}\text { data dapat } \\
\text { dijelaskan }\end{array}$ & $\begin{array}{l}\text { tidak dapat } \\
\text { dije laskan }\end{array}$ \\
\hline
\end{tabular}




\begin{tabular}{|c|c|c|c|c|c|c|c|c|c|}
\hline \multirow[t]{2}{*}{ No } & \multirow[t]{2}{*}{ Tahun } & \multirow[t]{2}{*}{ Judul } & \multirow[t]{2}{*}{ Permasalahan } & \multicolumn{4}{|c|}{ Metode Penelitian } & \multirow[t]{2}{*}{ Kes impulan } & \multirow[t]{2}{*}{ Ket } \\
\hline & & & & Sifat & Penalaran & $\begin{array}{c}\text { Pengumpulan } \\
\text { Data }\end{array}$ & $\begin{array}{l}\text { Me to de } \\
\text { Analis is }\end{array}$ & & \\
\hline 50 & 2004 & $\begin{array}{l}\text { Penelitian } \\
\text { Perbedaan } \\
\text { Ritual } \\
\text { Kematian pada } \\
\text { Tiga Ke lomp ok } \\
\text { Budaya di } \\
\text { Masyarakat } \\
\text { Dayak } \\
\text { Maan yan di } \\
\text { Barito Timur }\end{array}$ & $\begin{array}{l}\text { apa penyebab } \\
\text { perbedaan; } \\
\text { bagaimana } \\
\text { kehidupannya; } \\
\text { bagaimana } \\
\text { kondisi } \\
\text { lingkungannya }\end{array}$ & $\begin{array}{l}\text { tidak } \\
\text { disebutkan }\end{array}$ & $\begin{array}{l}\text { tidak } \\
\text { disebutkan }\end{array}$ & $\begin{array}{l}\text { survei- } \\
\text { wawancara }\end{array}$ & $\begin{array}{l}\text { tidak } \\
\text { disebutkan }\end{array}$ & $\begin{array}{l}\text { perma salahan } \\
\text { b elum } \\
\text { te jawab }\end{array}$ & tepat \\
\hline 51 & 2004 & $\begin{array}{l}\text { Penelitian } \\
\text { Etnoarke olog is } \\
\text { Religi Suku } \\
\text { Dayak } \\
\text { Tunjung di } \\
\text { Kabupaten } \\
\text { Kutai Barat } \\
\text { Kalimantan } \\
\text { Timur }\end{array}$ & $\begin{array}{l}\text { bagaimana } \\
\text { sistem religi; } \\
\text { bagaimana } \\
\text { hubungannya } \\
\text { dengan yang } \\
\text { lain }\end{array}$ & $\begin{array}{l}\text { tidak } \\
\text { disebutkan }\end{array}$ & $\begin{array}{l}\text { tidak } \\
\text { disebutkan }\end{array}$ & $\begin{array}{l}\text { survei- } \\
\text { wawancara }\end{array}$ & $\begin{array}{l}\text { tidak } \\
\text { disebutkan }\end{array}$ & $\begin{array}{l}\text { perma salahan } \\
\text { b elum } \\
\text { te rjawab }\end{array}$ & tepat \\
\hline 52 & 2005 & $\begin{array}{l}\text { Penelitian } \\
\text { Etnoarke ologi } \\
\text { Sistem } \\
\text { Penguburan } \\
\text { Masyarakat di } \\
\text { Kabupaten } \\
\text { Hulu Sung ai } \\
\text { Selatan }\end{array}$ & $\begin{array}{l}\text { bagaimana } \\
\text { sistem } \\
\text { penguburan }\end{array}$ & $\begin{array}{l}\text { deskriptif- } \\
\text { komparatif }\end{array}$ & induktif & $\begin{array}{l}\text { survei- } \\
\text { wawancara }\end{array}$ & $\begin{array}{l}\text { tidak } \\
\text { disebutkan }\end{array}$ & $\begin{array}{l}\text { perma salahan } \\
\text { te rjawab }\end{array}$ & tepat \\
\hline 53 & 2005 & $\begin{array}{l}\text { Penelitian } \\
\text { Etnoarkeologi } \\
\text { Religi pada } \\
\text { Masyarakat } \\
\text { Dayak Kenyah } \\
\text { di Hulu Sungai } \\
\text { Mahakam, } \\
\text { Kalimantan } \\
\text { Timur }\end{array}$ & $\begin{array}{l}\text { bagaimana } \\
\text { konsep religi; } \\
\text { bagaimana } \\
\text { kesin ambungan } \\
\text { budayanya }\end{array}$ & $\begin{array}{l}\text { deskriptif- } \\
\text { komparatif }\end{array}$ & ind uktif & $\begin{array}{l}\text { survei- } \\
\text { wawancara }\end{array}$ & klasifikasi & $\begin{array}{l}\text { perma salahan } \\
\text { belum } \\
\text { te rjawab }\end{array}$ & tepat \\
\hline 54 & 2005 & $\begin{array}{l}\text { Penelitian } \\
\text { Etnoarkeologi } \\
\text { Religi Suku } \\
\text { Dayak } \\
\text { Kanayatn di } \\
\text { Kabupaten } \\
\text { Landa, } \\
\text { Kalimantan } \\
\text { Barat }\end{array}$ & $\begin{array}{l}\text { bagaimana } \\
\text { konsep religi; } \\
\text { bagaimana } \\
\text { kesin ambungan } \\
\text { budayanya }\end{array}$ & $\begin{array}{l}\text { deskriptif- } \\
\text { komp aratif }\end{array}$ & ind uktif & $\begin{array}{l}\text { survei- } \\
\text { wawancara }\end{array}$ & $\begin{array}{l}\text { tidak } \\
\text { disebutkan }\end{array}$ & $\begin{array}{l}\text { tidak sinkron } \\
\text { dengan } \\
\text { masalah }\end{array}$ & tepat \\
\hline 55 & 2006 & $\begin{array}{l}\text { Jejak Puak- } \\
\text { puak } \\
\text { Austron esia di } \\
\text { Jantung } \\
\text { Kalimantan: } \\
\text { Situs Nanga } \\
\text { Balang dan } \\
\text { Ceruk Bukit } \\
\text { Tahapun, } \\
\text { Kabupaten } \\
\text { Kapuas Hulu, } \\
\text { Kalimantan } \\
\text { Barat } \\
\end{array}$ & tidak ada & $\begin{array}{l}\text { tidak } \\
\text { disebutkan }\end{array}$ & induktif & $\begin{array}{l}\text { tidak } \\
\text { disebutkan }\end{array}$ & $\begin{array}{l}\text { tidak } \\
\text { disebutkan }\end{array}$ & $\begin{array}{l}\text { data dapat } \\
\text { dijelaskan }\end{array}$ & $\begin{array}{l}\text { tidak dapat } \\
\text { dijelaskan }\end{array}$ \\
\hline 56 & 2006 & $\begin{array}{l}\text { Situs Masjid } \\
\text { Keramat } \\
\text { Banua Halat, } \\
\text { Kabupaten } \\
\text { Tapin, } \\
\text { Kalimantan } \\
\text { Selatan }\end{array}$ & $\begin{array}{l}\text { kapan masjid } \\
\text { didirikan }\end{array}$ & deskriptif & ind uktif & $\begin{array}{l}\text { survei- } \\
\text { ekska vasi }\end{array}$ & $\begin{array}{l}\text { analisis } \\
\text { pertanggalan }\end{array}$ & $\begin{array}{l}\text { perma salahan } \\
\text { te jawab }\end{array}$ & tepat \\
\hline
\end{tabular}




\begin{tabular}{|c|c|c|c|c|c|c|c|c|c|}
\hline \multirow[t]{2}{*}{ No } & \multirow[t]{2}{*}{ Tahun } & \multirow[t]{2}{*}{ Judul } & \multirow[t]{2}{*}{ Permasalahan } & \multicolumn{4}{|c|}{ Metode Penelitian } & \multirow[t]{2}{*}{ Kes impulan } & \multirow[t]{2}{*}{ Ket } \\
\hline & & & & Sifat & Penalaran & $\begin{array}{c}\text { Pengumpulan } \\
\text { Data }\end{array}$ & $\begin{array}{l}\text { Me tode } \\
\text { Analisis }\end{array}$ & & \\
\hline 57 & 2006 & $\begin{array}{l}\text { Penelitian Tata } \\
\text { Kota Kuna } \\
\text { Pontianak, } \\
\text { Mempawah, } \\
\text { dan Ngabang, } \\
\text { Kalimantan } \\
\text { Barat }\end{array}$ & $\begin{array}{l}\text { apa bentuk tata } \\
\text { kota kuna; } \\
\text { bagaimana } \\
\text { seba rannya }\end{array}$ & deskriptif & induktif & $\begin{array}{l}\text { survei- } \\
\text { wawan cara }\end{array}$ & $\begin{array}{l}\text { tidak } \\
\text { disebutkan }\end{array}$ & $\begin{array}{l}\text { perma salahan } \\
\text { terjawab }\end{array}$ & tepat \\
\hline 58 & 2006 & $\begin{array}{l}\text { Penelitian } \\
\text { Pusat-pusat } \\
\text { Kerajaan } \\
\text { Banjar Tahap } \\
\text { II di Kabupaten } \\
\text { Banjar, } \\
\text { Kalimantan } \\
\text { Selatan }\end{array}$ & tidak ada & $\begin{array}{l}\text { tidak } \\
\text { disebutkan }\end{array}$ & $\begin{array}{l}\text { tidak } \\
\text { disebutkan }\end{array}$ & $\begin{array}{l}\text { survei- } \\
\text { ekskavasi }\end{array}$ & $\begin{array}{l}\text { tidak } \\
\text { disebutkan }\end{array}$ & $\begin{array}{l}\text { tidak } \\
\text { teridentifikasi }\end{array}$ & tepat \\
\hline 59 & 2006 & $\begin{array}{l}\text { Ekskavasi } \\
\text { Situs Benteng } \\
\text { Oranje Nassau } \\
\text { Kecamatan } \\
\text { Penga ron, } \\
\text { Kabupaten } \\
\text { Banjar, } \\
\text { Kalimantan } \\
\text { Selatan }\end{array}$ & $\begin{array}{l}\text { bagaimana } \\
\text { kedudukan } \\
\text { benteng }\end{array}$ & deskriptif & induktif & $\begin{array}{l}\text { survei- } \\
\text { ekska vasi }\end{array}$ & $\begin{array}{l}\text { tidak } \\
\text { disebutkan }\end{array}$ & $\begin{array}{l}\text { perma salahan } \\
\text { belum } \\
\text { terjawab }\end{array}$ & tepat \\
\hline 60 & 2006 & $\begin{array}{l}\text { Lapo ran Hasil } \\
\text { Survei Kapal } \\
\text { Onrust di Hulu } \\
\text { Sungai Barito, } \\
\text { Muara Teweh, } \\
\text { Kalimantan } \\
\text { Tengah }\end{array}$ & $\begin{array}{l}\text { tidak } \\
\text { disebutkan }\end{array}$ & $\begin{array}{l}\text { tidak } \\
\text { d isebutkan }\end{array}$ & $\begin{array}{l}\text { tidak } \\
\text { disebutkan }\end{array}$ & $\begin{array}{l}\text { tidak } \\
\text { disebutkan }\end{array}$ & & $\begin{array}{l}\text { data dapat } \\
\text { dijelaskan }\end{array}$ & $\begin{array}{l}\text { tidak dapat } \\
\text { dijelaskan }\end{array}$ \\
\hline 61 & 2006 & $\begin{array}{l}\text { Penelitian } \\
\text { Etnoarke ologi } \\
\text { Pembuatan } \\
\text { Alat-alat logam } \\
\text { di Naga ra, } \\
\text { Kabupaten } \\
\text { Hulu Sung ai } \\
\text { Selatan }\end{array}$ & $\begin{array}{l}\text { bagaimana } \\
\text { proses } \\
\text { pembuatan; } \\
\text { mengapa } \\
\text { terkenal; } \\
\text { bagaimana } \\
\text { korela sinya } \\
\text { dengan } \\
\text { arkeologi }\end{array}$ & deskriptif & induktif & $\begin{array}{l}\text { survei- } \\
\text { wawan cara }\end{array}$ & $\begin{array}{l}\text { tidak } \\
\text { disebutkan }\end{array}$ & $\begin{array}{l}\text { perma salahan } \\
\text { belum } \\
\text { terjawab }\end{array}$ & tepat \\
\hline 62 & 2006 & $\begin{array}{l}\text { Penelitian } \\
\text { Tinggalan } \\
\text { Kubur } \\
\text { Penganut } \\
\text { Religi Iban Asli } \\
\text { di Kabupaten } \\
\text { Kapuas Hulu, } \\
\text { Kalimantan } \\
\text { Barat }\end{array}$ & $\begin{array}{l}\text { a pa bentuk } \\
\text { peralatannya; } \\
\text { bagaimana } \\
\text { konsep religi }\end{array}$ & $\begin{array}{l}\text { tidak } \\
\text { d isebutkan }\end{array}$ & $\begin{array}{l}\text { tidak } \\
\text { disebutkan }\end{array}$ & $\begin{array}{l}\text { survei- } \\
\text { wawan cara }\end{array}$ & $\begin{array}{l}\text { tidak } \\
\text { disebutkan }\end{array}$ & $\begin{array}{l}\text { tidak sinkron } \\
\text { dengan } \\
\text { masalah }\end{array}$ & tepat \\
\hline 63 & 2006 & $\begin{array}{l}\text { Inventarisasi } \\
\text { dan } \\
\text { Dokumentasi } \\
\text { Wayang Kulit } \\
\text { Banjar/Balar } \\
\text { Banjarmasin }\end{array}$ & $\begin{array}{l}\text { tidak } \\
\text { disebutkan }\end{array}$ & $\begin{array}{l}\text { tidak } \\
\text { disebutkan }\end{array}$ & $\begin{array}{l}\text { tidak } \\
\text { disebutkan }\end{array}$ & $\begin{array}{l}\text { tidak } \\
\text { disebutkan }\end{array}$ & $\begin{array}{l}\text { tidak } \\
\text { disebutkan }\end{array}$ & $\begin{array}{l}\text { data dapat } \\
\text { dijelaskan }\end{array}$ & $\begin{array}{l}\text { tidak dapat } \\
\text { dijelaskan }\end{array}$ \\
\hline 64 & 2006 & $\begin{array}{l}\text { Penelitian } \\
\text { Arkeologi di } \\
\text { DAS Kayan, } \\
\text { Kecamatan } \\
\text { Kayan Hulu, } \\
\text { Kabupaten } \\
\text { Malinau, } \\
\text { Kalimantan } \\
\text { Timur } \\
\end{array}$ & $\begin{array}{l}\text { tidak } \\
\text { disebutkan }\end{array}$ & $\begin{array}{l}\text { tidak } \\
\text { d isebutkan }\end{array}$ & $\begin{array}{l}\text { tidak } \\
\text { disebutkan }\end{array}$ & $\begin{array}{l}\text { survei- } \\
\text { ekskavasi }\end{array}$ & $\begin{array}{l}\text { tidak } \\
\text { disebutkan }\end{array}$ & $?$ & $\begin{array}{l}\text { tidak dapat } \\
\text { dijelaskan }\end{array}$ \\
\hline
\end{tabular}




\begin{tabular}{|c|c|c|c|c|c|c|c|c|c|}
\hline \multirow[t]{2}{*}{ No } & \multirow[t]{2}{*}{ Tahun } & \multirow[t]{2}{*}{ Judul } & \multirow[t]{2}{*}{ Permasalahan } & \multicolumn{4}{|c|}{ Metode Penelitian } & \multirow[t]{2}{*}{ Kes impulan } & \multirow[t]{2}{*}{ Ket } \\
\hline & & & & Sifat & Penalaran & $\begin{array}{l}\text { Pengumpulan } \\
\text { Data }\end{array}$ & $\begin{array}{l}\text { Me tode } \\
\text { Analis is }\end{array}$ & & \\
\hline 65 & 2007 & $\begin{array}{l}\text { Laporan Hasil } \\
\text { Ekskavasi } \\
\text { Penyelamatan } \\
\text { Kawasan Situs } \\
\text { Candi Agung, } \\
\text { Kabupaten } \\
\text { Hulu Sung ai } \\
\text { Utara, } \\
\text { Kalimantan } \\
\text { Selatan }\end{array}$ & $\begin{array}{l}\text { tidak } \\
\text { d isebutkan }\end{array}$ & $\begin{array}{l}\text { tidak } \\
\text { disebutkan }\end{array}$ & $\begin{array}{l}\text { tidak } \\
\text { disebutkan }\end{array}$ & ekskavasi & $\begin{array}{l}\text { a nalisis } \\
\text { a rtefaktual }\end{array}$ & $\begin{array}{l}\text { data dapat } \\
\text { dijelaskan }\end{array}$ & $\begin{array}{l}\text { tidak dapat } \\
\text { dijelaskan }\end{array}$ \\
\hline 66 & 2007 & $\begin{array}{l}\text { Penelitian } \\
\text { Aspek } \\
\text { Keruangan } \\
\text { Pola Tata Kota } \\
\text { Colonial di } \\
\text { Tarakan } \\
\text { Kabupaten } \\
\text { Tarakan } \\
\text { Provinsi } \\
\text { Kalimantan } \\
\text { Timur }\end{array}$ & a pa bentuk data & $\begin{array}{l}\text { tidak } \\
\text { disebutkan }\end{array}$ & $\begin{array}{l}\text { tidak } \\
\text { disebutkan }\end{array}$ & $\begin{array}{l}\text { survei- } \\
\text { wawancara }\end{array}$ & $\begin{array}{l}\text { tidak } \\
\text { d isebutkan }\end{array}$ & $\begin{array}{l}\text { perma salahan } \\
\text { terjawab }\end{array}$ & tepat \\
\hline 67 & 2007 & $\begin{array}{l}\text { Temuan } \\
\text { Tonggak Kayu } \\
\text { Ulin Di Desa } \\
\text { Patih Muhur } \\
\text { Lama } \\
\text { Kecamatan } \\
\text { Anjir Muara, } \\
\text { Kabupaten } \\
\text { Barito Kuala }\end{array}$ & $\begin{array}{l}\text { tidak } \\
\text { disebutkan }\end{array}$ & $\begin{array}{l}\text { tidak } \\
\text { disebutkan }\end{array}$ & $\begin{array}{l}\text { tidak } \\
\text { disebutkan }\end{array}$ & $\begin{array}{l}\text { tidak } \\
\text { disebutkan }\end{array}$ & $\begin{array}{l}\text { tidak } \\
\text { d isebutkan }\end{array}$ & $\begin{array}{l}\text { data dapat } \\
\text { dijelaskan }\end{array}$ & $\begin{array}{l}\text { tidak dapat } \\
\text { dije laskan }\end{array}$ \\
\hline 68 & 2007 & $\begin{array}{l}\text { Penelitian } \\
\text { Ekskavasi } \\
\text { Pemukiman Di } \\
\text { Nagara } \\
\text { Kabupaten } \\
\text { Hulu Sung ai } \\
\text { Selatan } \\
\text { Kalimantan } \\
\text { Selatan }\end{array}$ & $\begin{array}{l}\text { bagaimana } \\
\text { sebaran hunian } \\
\text { dan } \\
\text { peranannya }\end{array}$ & $\begin{array}{l}\text { tidak } \\
\text { d isebutkan }\end{array}$ & $\begin{array}{l}\text { tidak } \\
\text { disebutkan }\end{array}$ & $\begin{array}{l}\text { survei- } \\
\text { ekskavasi }\end{array}$ & $\begin{array}{l}\text { a nalisis } \\
\text { a rtefaktual }\end{array}$ & $\begin{array}{l}\text { perma salahan } \\
\text { terjawab }\end{array}$ & tepat \\
\hline 69 & 2007 & $\begin{array}{l}\text { Ekskavasi } \\
\text { Permukiman } \\
\text { Lahan Basah } \\
\text { di Situs } \\
\text { Gambut, } \\
\text { Kabupaten } \\
\text { Banjar dan } \\
\text { Patih Muhur } \\
\text { Kabupaten } \\
\text { Barito Kuala } \\
\text { Kalimantan } \\
\text { Selatan }\end{array}$ & $\begin{array}{l}\text { bagaimana } \\
\text { hubungan } \\
\text { a ntarsitus; } \\
\text { bagaimana pola } \\
\text { huniannya }\end{array}$ & $\begin{array}{l}\text { tidak } \\
\text { disebutkan }\end{array}$ & $\begin{array}{l}\text { tidak } \\
\text { disebutkan }\end{array}$ & $\begin{array}{l}\text { survei- } \\
\text { ekskavasi }\end{array}$ & $\begin{array}{l}\text { a nalisis } \\
\text { a rtefaktual; } \\
\text { a nalisis } \\
\text { stratigrafi }\end{array}$ & $\begin{array}{l}\text { perma salahan } \\
\text { belum } \\
\text { terjawab }\end{array}$ & tepat \\
\hline 70 & 2007 & $\begin{array}{l}\text { Pemukiman } \\
\text { Pra sejarah } \\
\text { Situs Jambu } \\
\text { Hilir, } \\
\text { kecamatan } \\
\text { Kandangan, } \\
\text { Kabupaten } \\
\text { Hulu Sungai } \\
\text { Selatan } \\
\text { Provinsi } \\
\text { Kalimantan } \\
\text { Selatan }\end{array}$ & $\begin{array}{l}\text { kapan situs } \\
\text { dihuni; apa } \\
\text { jenis } \\
\text { aktivitasnya }\end{array}$ & $\begin{array}{l}\text { tidak } \\
\text { disebutkan }\end{array}$ & $\begin{array}{l}\text { tidak } \\
\text { disebutkan }\end{array}$ & $\begin{array}{l}\text { survei- } \\
\text { ekskavasi }\end{array}$ & $\begin{array}{l}\text { a nalisis } \\
\text { artefaktual; } \\
\text { analisis } \\
\text { pertang galan }\end{array}$ & $\begin{array}{l}\text { perma salahan } \\
\text { terjawab }\end{array}$ & tepat \\
\hline 71 & 2009 & $\begin{array}{l}\text { Jejak-jejak } \\
\text { Hindu-Buddha } \\
\text { di Sepauk } \\
\text { Kabupaten } \\
\text { Sintang } \\
\text { Kalimantan } \\
\text { Barat }\end{array}$ & $\begin{array}{l}\text { bagaimana } \\
\text { karakter situs; } \\
\text { bagaimana } \\
\text { pemanfaatan } \\
\text { ruang secara } \\
\text { vertikal dan } \\
\text { horisontal; } \\
\text { bagaimana } \\
\text { posisi situs } \\
\text { dalam ke rangka } \\
\text { budaya Hindu- } \\
\text { Buddha di } \\
\text { Kalimantan }\end{array}$ & deskriptif & induktif & $\begin{array}{l}\text { survei-studi } \\
\text { pustaka- } \\
\text { wawancara }\end{array}$ & $\begin{array}{l}\text { a nalisis } \\
\text { khusus; } \\
\text { konte kstual; } \\
\text { ruang; } \\
\text { komparatif; } \\
\text { etnoarkeo logi }\end{array}$ & $\begin{array}{l}\text { perma salahan } \\
\text { belum } \\
\text { terjawab }\end{array}$ & tepat \\
\hline
\end{tabular}




\begin{tabular}{|c|c|c|c|c|c|c|c|c|c|}
\hline \multirow[t]{2}{*}{ No } & \multirow[t]{2}{*}{ Tahun } & \multirow[t]{2}{*}{ Judul } & \multirow[t]{2}{*}{ Permasalahan } & \multicolumn{4}{|c|}{ Metode Penelitian } & \multirow[t]{2}{*}{ Kes impulan } & \multirow[t]{2}{*}{ Ket } \\
\hline & & & & Sifat & Penalaran & $\begin{array}{l}\text { Pengumpulan } \\
\text { Data }\end{array}$ & $\begin{array}{l}\text { Me tode } \\
\text { Analis is }\end{array}$ & & \\
\hline 72 & 2009 & $\begin{array}{l}\text { Penelitian } \\
\text { Potensi } \\
\text { Arkeologi di } \\
\text { Kabupaten } \\
\text { Kayong Utara } \\
\text { Kalimantan } \\
\text { Barat }\end{array}$ & $\begin{array}{l}\text { a pa potensi } \\
\text { data; apa } \\
\text { seba ran data; } \\
\text { bagaimana } \\
\text { peran dan } \\
\text { fungsi situs; }\end{array}$ & $\begin{array}{l}\text { eksploratif- } \\
\text { deskriptif }\end{array}$ & induktif & $\begin{array}{l}\text { survei- } \\
\text { ekskavasi }\end{array}$ & $\begin{array}{l}\text { tidak } \\
\text { disebutkan }\end{array}$ & $\begin{array}{l}\text { tidak sinkron } \\
\text { dengan } \\
\text { masalah }\end{array}$ & $\begin{array}{l}\text { gabungan } \\
\text { eksp loratif- } \\
\text { deskniptif }\end{array}$ \\
\hline 73 & 2009 & $\begin{array}{l}\text { Korelasi Mitos } \\
\text { dan Ap resia si } \\
\text { Masyarakat } \\
\text { terhadap } \\
\text { Pelestraian } \\
\text { Situs Candi } \\
\text { Agung di } \\
\text { Amuntai } \\
\text { Kalimantan } \\
\text { Selatan }\end{array}$ & $\begin{array}{l}\text { a pa mitos yang } \\
\text { berperan; } \\
\text { b agaimana } \\
\text { p roses; } \\
\text { bagaimana } \\
\text { perilaku }\end{array}$ & deskriptif & induktif & $\begin{array}{l}\text { studi pustaka- } \\
\text { wawan cara }\end{array}$ & $\begin{array}{l}\text { tidak } \\
\text { disebutkan }\end{array}$ & $\begin{array}{l}\text { perma salahan } \\
\text { te jawab }\end{array}$ & tepat \\
\hline 74 & 2009 & $\begin{array}{l}\text { Penelitian } \\
\text { Peninggalan } \\
\text { Masa Kolonial } \\
\text { di Kabupaten } \\
\text { Barito Utara } \\
\text { dan Kabupaten } \\
\text { Murung Raya } \\
\text { Provinsi } \\
\text { Kalimantan } \\
\text { Tengah }\end{array}$ & $\begin{array}{l}\text { tidak } \\
\text { disebutkan }\end{array}$ & $\begin{array}{l}\text { tidak } \\
\text { disebutkan }\end{array}$ & $\begin{array}{l}\text { tidak } \\
\text { disebutkan }\end{array}$ & $\begin{array}{l}\text { survei- } \\
\text { wawan cara }\end{array}$ & $\begin{array}{l}\text { tidak } \\
\text { disebutkan }\end{array}$ & $\begin{array}{l}\text { data dapat } \\
\text { d jijelaskan }\end{array}$ & $\begin{array}{l}\text { tidak dapat } \\
\text { dije laskan }\end{array}$ \\
\hline 75 & 2009 & $\begin{array}{l}\text { Pemukiman } \\
\text { Prasejarah } \\
\text { Situs Jambu } \\
\text { Hilir dan } \\
\text { Jambu Hulu } \\
\text { Kecamatan } \\
\text { Padang } \\
\text { BAtung, } \\
\text { Kabupaten } \\
\text { Hulu Sungai } \\
\text { Selatan } \\
\text { Provinsi } \\
\text { Kalimantan } \\
\text { Selatan }\end{array}$ & $\begin{array}{l}\text { bagaimana } \\
\text { sebaran data; } \\
\text { bagaimana } \\
\text { hubungan } \\
\text { antarsitus }\end{array}$ & $\begin{array}{l}\text { tidak } \\
\text { disebutkan }\end{array}$ & $\begin{array}{l}\text { tidak } \\
\text { disebutkan }\end{array}$ & $\begin{array}{l}\text { survei- } \\
\text { ekskavasi }\end{array}$ & $\begin{array}{l}\text { analisis } \\
\text { artefaktual; } \\
\text { analisis } \\
\text { pertang galan }\end{array}$ & $\begin{array}{l}\text { perma salahan } \\
\text { belum } \\
\text { te jawab }\end{array}$ & tepat \\
\hline 76 & 2009 & $\begin{array}{l}\text { Penelitian } \\
\text { Sistem } \\
\text { Tekn ologi } \\
\text { Tradisional } \\
\text { Masyarakat } \\
\text { Bawo Di } \\
\text { Kabupaten } \\
\text { Barito Selatan } \\
\text { Kalimantan } \\
\text { Tengah }\end{array}$ & $\begin{array}{l}\text { a pa tipolo gi } \\
\text { alatanya; siapa } \\
\text { Bawo }\end{array}$ & deskriptif & induktif & survei & $\begin{array}{l}\text { tidak } \\
\text { disebutkan }\end{array}$ & $\begin{array}{l}\text { perma salahan } \\
\text { te jiawab }\end{array}$ & tepat \\
\hline 77 & 2010 & $\begin{array}{l}\text { Penelitian } \\
\text { Sumber Bahan } \\
\text { Alat Batu Situs } \\
\text { Awang } \\
\text { Bangkal }\end{array}$ & $\begin{array}{l}\text { a pa jenis } \\
\text { b atuan; di mana } \\
\text { sumber dan } \\
\text { situs; } \\
\text { bagaimana } \\
\text { tradisi } \\
\end{array}$ & deskriptif & induktif & survei & $\begin{array}{l}\text { analisis } \\
\text { sitecatchment } \\
; \\
\text { geomorfologi }\end{array}$ & $\begin{array}{l}\text { permasalahan } \\
\text { te jawab }\end{array}$ & tepat \\
\hline 78 & 2010 & $\begin{array}{l}\text { Penelitian } \\
\text { Situs } \\
\text { Pra sejarah } \\
\text { Gua Bangkai } \\
\text { Kecamatan } \\
\text { Mantewe, } \\
\text { Kabupaten } \\
\text { Tanah Bumbu, } \\
\text { Provinsi } \\
\text { Kalimantan } \\
\text { Selatan }\end{array}$ & $\begin{array}{l}\text { a pa data } \\
\text { hunian; siapa } \\
\text { penghuni; } \\
\text { bagaimana } \\
\text { karakter hun ian }\end{array}$ & $\begin{array}{l}\text { tidak } \\
\text { disebutkan }\end{array}$ & $\begin{array}{l}\text { tidak } \\
\text { disebutkan }\end{array}$ & $\begin{array}{l}\text { survei- } \\
\text { ekskavasi }\end{array}$ & $\begin{array}{l}\text { analisis } \\
\text { artefaktual }\end{array}$ & $\begin{array}{l}\text { permasalahan } \\
\text { te jawab }\end{array}$ & tepat \\
\hline
\end{tabular}




\begin{tabular}{|c|c|c|c|c|c|c|c|c|c|}
\hline \multirow[t]{2}{*}{ No } & \multirow[t]{2}{*}{ Tahun } & \multirow[t]{2}{*}{ Judul } & \multirow[t]{2}{*}{ Permasalahan } & \multicolumn{4}{|c|}{ Metode Penelitian } & \multirow[t]{2}{*}{ Kes impulan } & \multirow[t]{2}{*}{ Ket } \\
\hline & & & & Sifat & Penalaran & $\begin{array}{c}\text { Pengumpulan } \\
\text { Data }\end{array}$ & $\begin{array}{l}\text { Me tode } \\
\text { Analis is }\end{array}$ & & \\
\hline 79 & 2010 & $\begin{array}{l}\text { Ekskavasi } \\
\text { Situs Negeri } \\
\text { Baru } \\
\text { Kabupaten } \\
\text { Ketapang } \\
\text { Kalimantan } \\
\text { Barat }\end{array}$ & $\begin{array}{l}\text { apa jenis } \\
\text { bangunan; apa } \\
\text { denahnya; apa } \\
\text { fungsinya }\end{array}$ & deskriptif & induktif & $\begin{array}{l}\text { survei- } \\
\text { ekskavasi }\end{array}$ & $\begin{array}{l}\text { analisis } \\
\text { artefaktual }\end{array}$ & $\begin{array}{l}\text { perma salahan } \\
\text { belum } \\
\text { te rjawab }\end{array}$ & tepat \\
\hline 80 & 2010 & $\begin{array}{l}\text { Penelitian } \\
\text { Arkeologi } \\
\text { Masa Kolonial } \\
\text { di Kabupaten } \\
\text { Kutai Barat, } \\
\text { Provinsi } \\
\text { Kalimantan } \\
\text { Timur }\end{array}$ & $\begin{array}{l}\text { tidak } \\
\text { disebutkan }\end{array}$ & $\begin{array}{l}\text { eksploratif- } \\
\text { deskriptif }\end{array}$ & induktif & $\begin{array}{l}\text { survei- } \\
\text { wawan cara }\end{array}$ & $\begin{array}{l}\text { tidak } \\
\text { disebutkan }\end{array}$ & $\begin{array}{l}\text { data dapat } \\
\text { dijelaskan }\end{array}$ & $\begin{array}{l}\text { tidak dapat } \\
\text { dijelaskan }\end{array}$ \\
\hline 81 & 2010 & $\begin{array}{l}\text { Penelitian } \\
\text { Perkembangan } \\
\text { Kota Pleihari } \\
\text { dan Wilayah di } \\
\text { Sekita mya di } \\
\text { Kabupaten } \\
\text { Tanah Laut } \\
\text { Provinsi } \\
\text { Kalimantan } \\
\text { Selatan }\end{array}$ & $\begin{array}{l}\text { apa bentuk } \\
\text { bangunan dan } \\
\text { tata ruang ko ta }\end{array}$ & deskriptif & induktif & $\begin{array}{l}\text { survei-studi } \\
\text { pustaka- } \\
\text { wawan cara }\end{array}$ & $\begin{array}{l}\text { analisis } \\
\text { ruang; } \\
\text { kontekstual; } \\
\text { komparatif }\end{array}$ & $\begin{array}{l}\text { permasalahan } \\
\text { terjawab }\end{array}$ & tepat \\
\hline 82 & 2010 & $\begin{array}{l}\text { Penelitian } \\
\text { Pemukiman } \\
\text { Cina Awal di } \\
\text { Singkawang } \\
\text { Provinsi } \\
\text { Kalimantan } \\
\text { Barat }\end{array}$ & $\begin{array}{l}\text { dimana } \\
\text { pemukiman } \\
\text { awalnya }\end{array}$ & deskriptif & ind uktif & $\begin{array}{l}\text { survei-studi } \\
\text { pustaka- } \\
\text { wawan cara }\end{array}$ & $\begin{array}{l}\text { tidak } \\
\text { disebutkan }\end{array}$ & $\begin{array}{l}\text { perma salahan } \\
\text { te rjawab }\end{array}$ & tepat \\
\hline 83 & 2010 & $\begin{array}{l}\text { Kubur Tajau } \\
\text { Sanga Sanga } \\
\text { Kabupaten } \\
\text { Kutai } \\
\text { Kertanegara } \\
\text { Kalimantan } \\
\text { Timur }\end{array}$ & $\begin{array}{l}\text { apa karakter } \\
\text { situs; kapan } \\
\text { periodesasinya; } \\
\text { siapa } \\
\text { pendukungnya }\end{array}$ & deskriptif & induktif & $\begin{array}{l}\text { survei- } \\
\text { ekskavasi }\end{array}$ & $\begin{array}{l}\text { a nalisis } \\
\text { artefaktual; } \\
\text { a nalisis } \\
\text { pertang galan }\end{array}$ & $\begin{array}{l}\text { perma salahan } \\
\text { terjawab }\end{array}$ & tepat \\
\hline 84 & 2011 & $\begin{array}{l}\text { Penelitian } \\
\text { Arkeologi di } \\
\text { Da erah Aliran } \\
\text { Sungai } \\
\text { Sepauk, } \\
\text { Kabupaten } \\
\text { Sintang, } \\
\text { Kalimantan } \\
\text { Barat }\end{array}$ & $\begin{array}{l}\text { a pa ragam } \\
\text { data; apa } \\
\text { karakteristik }\end{array}$ & deskriptif & induktif & $\begin{array}{l}\text { survei- } \\
\text { ekskavasi }\end{array}$ & $\begin{array}{l}\text { a nalisis } \\
\text { a rtefaktual; } \\
\text { analisis } \\
\text { lingkungan }\end{array}$ & $\begin{array}{l}\text { perma salahan } \\
\text { te rjawab }\end{array}$ & tepat \\
\hline 85 & 2011 & $\begin{array}{l}\text { Penelitian } \\
\text { Arkeologi } \\
\text { Permukiman } \\
\text { Jambu Hulu, } \\
\text { Kecamatan } \\
\text { Padang } \\
\text { Batung, } \\
\text { Kabupaten } \\
\text { Hulu Sung ai } \\
\text { Selatan, } \\
\text { Kalimantan } \\
\text { Selatan }\end{array}$ & $\begin{array}{l}\text { bagaimana } \\
\text { sebaran da a; } \\
\text { bagaimana } \\
\text { hubungan } \\
\text { antarsitus }\end{array}$ & deskriptif & induktif & $\begin{array}{l}\text { survei- } \\
\text { ekskavasi }\end{array}$ & $\begin{array}{l}\text { a nalisis } \\
\text { a rtefaktual; } \\
\text { a nalisis } \\
\text { pertang galan }\end{array}$ & $\begin{array}{l}\text { perma salahan } \\
\text { belum } \\
\text { terjawab }\end{array}$ & tepat \\
\hline
\end{tabular}




\begin{tabular}{|c|c|c|c|c|c|c|c|c|c|}
\hline \multirow[t]{2}{*}{ No } & \multirow[t]{2}{*}{ Tahun } & \multirow[t]{2}{*}{ Judul } & \multirow[t]{2}{*}{ Permasalahan } & \multicolumn{4}{|c|}{ Metode Penelitian } & \multirow[t]{2}{*}{ Kes impulan } & \multirow[t]{2}{*}{ Ket } \\
\hline & & & & Sifat & Penalaran & $\begin{array}{c}\text { Pengumpulan } \\
\text { Data }\end{array}$ & $\begin{array}{l}\text { Metode } \\
\text { Analis is }\end{array}$ & & \\
\hline 86 & 2011 & $\begin{array}{l}\text { Kubur Tajau } \\
\text { Sanga Sanga } \\
\text { Kabupaten } \\
\text { Kutai } \\
\text { Kertanegara } \\
\text { Provinsi } \\
\text { Kalimantan } \\
\text { Timur }\end{array}$ & $\begin{array}{l}\text { berapa luas } \\
\text { situs; } \\
\text { bagaimana } \\
\text { karakter } \\
\text { penguburannya }\end{array}$ & deskriptif & induktif & $\begin{array}{l}\text { survei- } \\
\text { ekskavasi }\end{array}$ & $\begin{array}{l}\text { analisis } \\
\text { artefaktual }\end{array}$ & $\begin{array}{l}\text { permasalahan } \\
\text { te rjawab }\end{array}$ & tepat \\
\hline 87 & 2011 & $\begin{array}{l}\text { Penelitian } \\
\text { Etnoarke ologi } \\
\text { Peralatan } \\
\text { Re ligi Suku } \\
\text { Dayak Meratus } \\
\text { di Kabupaten } \\
\text { Balangan } \\
\text { Kalimantan } \\
\text { Selatan }\end{array}$ & $\begin{array}{l}\text { bagaimana } \\
\text { konsep religi }\end{array}$ & $\begin{array}{l}\text { deskriptif- } \\
\text { komp aratif }\end{array}$ & induktif & $\begin{array}{l}\text { survei- } \\
\text { wawancara }\end{array}$ & $\begin{array}{l}\text { analisis } \\
\text { komparasi }\end{array}$ & $\begin{array}{l}\text { permasalahan } \\
\text { te rjawab }\end{array}$ & tepat \\
\hline 88 & 2011 & $\begin{array}{l}\text { Situs Kubur } \\
\text { dan Ap resiasi } \\
\text { Peziarah: } \\
\text { Manfaat dalam } \\
\text { Pelestarian } \\
\text { Situs Kubur } \\
\text { Sultan } \\
\text { Surian syah di } \\
\text { Banjarmasin } \\
\text { dan Datu } \\
\text { Sanggul di } \\
\text { Tapin, } \\
\text { Kalimantan } \\
\text { Selatan }\end{array}$ & $\begin{array}{l}\text { bagaimana } \\
\text { praktek } \\
\text { pengelolaan; } \\
\text { bagaimana } \\
\text { persepsi } \\
\text { peziarah }\end{array}$ & deskriptif & induktif & $\begin{array}{l}\text { survei- } \\
\text { wawancara }\end{array}$ & $\begin{array}{l}\text { analisis } \\
\text { reduksi data }\end{array}$ & $\begin{array}{l}\text { permasalahan } \\
\text { te rjawab }\end{array}$ & tepat \\
\hline 89 & 2012 & $\begin{array}{l}\text { Penelitian } \\
\text { Situs Liang } \\
\text { Bangkai, } \\
\text { Kecamatan } \\
\text { Mantewe, } \\
\text { Kabupaten } \\
\text { Tanah Bumbu, } \\
\text { Provinsi } \\
\text { Kalimantan } \\
\text { Selatan Tahap } \\
\text { IV }\end{array}$ & $\begin{array}{l}\text { bagaimana } \\
\text { karakter; } \\
\text { bagaimana tata } \\
\text { ruang; siapa } \\
\text { penghuni }\end{array}$ & $\begin{array}{l}\text { tidak } \\
\text { disebutkan }\end{array}$ & $\begin{array}{l}\text { tidak } \\
\text { disebutkan }\end{array}$ & $\begin{array}{l}\text { survei- } \\
\text { eskavasi }\end{array}$ & $\begin{array}{l}\text { analisis } \\
\text { artefaktual }\end{array}$ & $\begin{array}{l}\text { permasalahan } \\
\text { belum } \\
\text { terjawab }\end{array}$ & tepat \\
\hline 90 & 2012 & $\begin{array}{l}\text { Penelitian } \\
\text { Arkeologi } \\
\text { Prasejarah } \\
\text { Situs Awang } \\
\text { Bangkal di } \\
\text { Hulu Sungai } \\
\text { Riam Kanan }\end{array}$ & $\begin{array}{l}\text { apa potensi } \\
\text { data; } \\
\text { bagaimana pola } \\
\text { budaya }\end{array}$ & deskriptif & induktif & survei & $\begin{array}{l}\text { analisis } \\
\text { artefaktual }\end{array}$ & $\begin{array}{l}\text { permasalahan } \\
\text { te rjawab }\end{array}$ & tepat \\
\hline 91 & 2012 & $\begin{array}{l}\text { Arsitektur } \\
\text { Masjid Kuna } \\
\text { Kabupaten } \\
\text { Tabalong, Hulu } \\
\text { SungaiUtara } \\
\text { dan Balangan } \\
\text { Kalimantan } \\
\text { Selatan }\end{array}$ & $\begin{array}{l}\text { apa bentuk } \\
\text { arsitektur } \\
\text { masijid }\end{array}$ & deskriptif & induktif & $\begin{array}{l}\text { survei- } \\
\text { wawan cara }\end{array}$ & $\begin{array}{l}\text { analisis } \\
\text { arsitektur }\end{array}$ & $\begin{array}{l}\text { permasalahan } \\
\text { te rjawab }\end{array}$ & tepat \\
\hline 92 & 2012 & $\begin{array}{l}\text { Eksplorasi } \\
\text { Peninggalan } \\
\text { Arkeologi di } \\
\text { Kabupaten } \\
\text { Bulungan } \\
\text { Provinsi } \\
\text { Kalimantan } \\
\text { Timur }\end{array}$ & $\begin{array}{l}\text { apa bentuk dan } \\
\text { sebaran di } \\
\text { mana lokasi } \\
\text { pusat } \\
\text { peradaban }\end{array}$ & deskriptif & induktif & $\begin{array}{l}\text { survei-studi } \\
\text { pustaka- } \\
\text { wawancara }\end{array}$ & $\begin{array}{l}\text { tidak } \\
\text { disebutkan }\end{array}$ & $\begin{array}{l}\text { tidak sinkron } \\
\text { dengan } \\
\text { masalah }\end{array}$ & tepat \\
\hline
\end{tabular}




\begin{tabular}{|c|c|c|c|c|c|c|c|c|c|}
\hline \multirow[t]{2}{*}{ No } & \multirow[t]{2}{*}{ Tahun } & \multirow[t]{2}{*}{ Judul } & \multirow[t]{2}{*}{ Permasalahan } & \multicolumn{4}{|c|}{ Metode Penelitian } & \multirow[t]{2}{*}{ Kes impulan } & \multirow[t]{2}{*}{ Ket } \\
\hline & & & & Sifat & Penalaran & $\begin{array}{c}\text { Pengumpulan } \\
\text { Data }\end{array}$ & $\begin{array}{l}\text { Me tode } \\
\text { Analis is }\end{array}$ & & \\
\hline 93 & 2012 & $\begin{array}{l}\text { Penelitian } \\
\text { Arkeologi Situs } \\
\text { Pulau } \\
\text { Jangkung } \\
\text { Kabupaten } \\
\text { Tabalong, } \\
\text { Kalimantan } \\
\text { Selatan }\end{array}$ & $\begin{array}{l}\text { apa potensi; } \\
\text { berapa usia } \\
\text { situs; } \\
\text { bagaimana } \\
\text { sebaran hunian }\end{array}$ & deskniptif & induktif & $\begin{array}{l}\text { survei- } \\
\text { wawancara }\end{array}$ & $\begin{array}{l}\text { analisis } \\
\text { artefaktual; } \\
\text { analisis } \\
\text { stratigrafi; } \\
\text { analisis } \\
\text { kontekstual; } \\
\text { analisis } \\
\text { pertanggalan }\end{array}$ & $\begin{array}{l}\text { permasalahan } \\
\text { terjawab }\end{array}$ & tepat \\
\hline 94 & 2012 & $\begin{array}{l}\text { Religi dan } \\
\text { Teknologi } \\
\text { Tradisional } \\
\text { Suku Dayak } \\
\text { Meratus di } \\
\text { Kabupaten } \\
\text { Kotabaru, } \\
\text { Kalimantan } \\
\text { Selatan }\end{array}$ & $\begin{array}{l}\text { bagaimana } \\
\text { konsep religi; } \\
\text { siapakah Dayak } \\
\text { Meratus }\end{array}$ & $\begin{array}{l}\text { tidak } \\
\text { disebutkan }\end{array}$ & $\begin{array}{l}\text { tidak } \\
\text { disebutkan }\end{array}$ & $\begin{array}{l}\text { survei- } \\
\text { wawancara }\end{array}$ & $\begin{array}{l}\text { tidak } \\
\text { disebutkan }\end{array}$ & $\begin{array}{l}\text { permasalahan } \\
\text { terjawab }\end{array}$ & tepat \\
\hline 95 & 2012 & $\begin{array}{l}\text { Persepsi } \\
\text { ParaStake hold } \\
\text { er dalam } \\
\text { Pelestarian } \\
\text { Situs Sanga- } \\
\text { Sanga di } \\
\text { Kabupaten } \\
\text { Kutai } \\
\text { Kertanegara, } \\
\text { Kalimantan } \\
\text { Timur } \\
\end{array}$ & $\begin{array}{l}\text { bagaimana } \\
\text { karakter } \\
\text { stakeholder }\end{array}$ & deskniptif & induktif & \begin{tabular}{|l} 
survei- \\
wawancara
\end{tabular} & $\begin{array}{l}\text { tidak } \\
\text { disebutkan }\end{array}$ & $\begin{array}{l}\text { permasalahan } \\
\text { terjawab }\end{array}$ & tepat \\
\hline 96 & 2013 & $\begin{array}{l}\text { Survei dan } \\
\text { Ekskavasi } \\
\text { Situs Liang } \\
\text { Bangkai Desa } \\
\text { Dukuhrejo, } \\
\text { Kecamatan } \\
\text { Mantewe, } \\
\text { Kabupaten } \\
\text { Tanah Bumbu, } \\
\text { Kalimantan } \\
\text { Selatan } \\
\end{array}$ & $\begin{array}{l}\text { dimana su mber } \\
\text { bahan; } \\
\text { bagaimana } \\
\text { sebaran dan } \\
\text { karakteristik } \\
\text { hunian }\end{array}$ & deskniptif & induktif & \begin{tabular}{|l|} 
survei- \\
ekskavasi
\end{tabular} & \begin{tabular}{|l} 
analisis \\
artefaktual
\end{tabular} & $\begin{array}{l}\text { permasalahan } \\
\text { terjawab }\end{array}$ & tepat \\
\hline 97 & 2013 & $\begin{array}{l}\text { Lingkungan } \\
\text { Masjid Pelajau } \\
\text { di Kabupaten } \\
\text { Hulu Sungai } \\
\text { Selatan, } \\
\text { Kalimantan } \\
\text { Selatan }\end{array}$ & $\begin{array}{l}\text { apa faktor } \\
\text { pemilihan lokasi } \\
\text { situs; } \\
\text { bagaimana } \\
\text { kondisi } \\
\text { lingkungannya }\end{array}$ & deskriptif & ind uktif & $\begin{array}{l}\text { survei- } \\
\text { e kskavasi- } \\
\text { wawancara }\end{array}$ & $\begin{array}{l}\text { analisis } \\
\text { tipologi; } \\
\text { morfologi; } \\
\text { teknolog is }\end{array}$ & $\begin{array}{l}\text { permasalahan } \\
\text { belum } \\
\text { terjawab }\end{array}$ & tepat \\
\hline 98 & 2013 & $\begin{array}{l}\text { Simbol Denah } \\
\text { Rumah Banjar: } \\
\text { Analisis } \\
\text { Berdasarkan } \\
\text { Pemikiran } \\
\text { Masyarakat } \\
\text { Penggunanya }\end{array}$ & $\begin{array}{l}\text { apa simbol di } \\
\text { balik denah } \\
\text { rumah; } \\
\text { bagaimana } \\
\text { pemikiran orang } \\
\text { mengenai } \\
\text { denah rumah } \\
\end{array}$ & deskriptif & induktif & $\begin{array}{l}\text { Survei- } \\
\text { wawancara }\end{array}$ & $\begin{array}{l}\text { analisis de ep } \\
\text { structure }\end{array}$ & $\begin{array}{l}\text { permasalahan } \\
\text { terjawab }\end{array}$ & tepat \\
\hline
\end{tabular}


Tabel 3. Daftar Judul LPA Eksplanatif di Balar Banjarmasin Tahun 1993-2013.

\begin{tabular}{|c|c|c|c|c|c|c|c|c|c|}
\hline \multirow[t]{2}{*}{ No } & \multirow[t]{2}{*}{ Tahun } & \multirow[t]{2}{*}{ Judul } & \multirow[t]{2}{*}{ Permasalahan } & \multicolumn{4}{|c|}{ Metode Penelitian } & \multirow[t]{2}{*}{ Kes impulan } & \multirow[t]{2}{*}{ Ket } \\
\hline & & & & Sifat & Penalaran & $\begin{array}{c}\text { Pengumpulan } \\
\text { Data }\end{array}$ & $\begin{array}{l}\text { Metode } \\
\text { Analis is }\end{array}$ & & \\
\hline 1 & 2003 & $\begin{array}{l}\text { Tata Cara } \\
\text { Prosesi } \\
\text { Penguburan } \\
\text { dan Upacara } \\
\text { ljambe di } \\
\text { Kecamatan } \\
\text { Dusun Timur, } \\
\text { Kabupaten } \\
\text { Barito Timur, } \\
\text { Kalimantan } \\
\text { Tengah } \\
\end{array}$ & $\begin{array}{l}\text { apa jenis data; } \\
\text { bagaimana cara } \\
\text { dan prosesnya; } \\
\text { bagaimana } \\
\text { konsepnya; } \\
\text { siapa tokohnya; } \\
\text { bagaimana } \\
\text { kesin ambungan } \\
\text { budayanya }\end{array}$ & $\begin{array}{l}\text { deskriptif- } \\
\text { eksplanatif }\end{array}$ & induktif & $\begin{array}{l}\text { survei- } \\
\text { wawancara }\end{array}$ & $\begin{array}{l}\text { identifikasi; } \\
\text { klasifikasi }\end{array}$ & $\begin{array}{l}\text { permasalahan } \\
\text { belum } \\
\text { terjawab }\end{array}$ & $\begin{array}{l}\text { belum } \\
\text { tepat }\end{array}$ \\
\hline 2 & 2004 & $\begin{array}{l}\text { Penelitian } \\
\text { Arsitektur } \\
\text { Rumah Adat } \\
\text { Lamin di } \\
\text { Kecamatan } \\
\text { Jempang, } \\
\text { Kabupaten } \\
\text { Kutai Barat } \\
\text { Kalimantan } \\
\text { Timur }\end{array}$ & $\begin{array}{l}\text { tidak } \\
\text { disebutkan }\end{array}$ & $\begin{array}{l}\text { deskriptif- } \\
\text { eksplanatif }\end{array}$ & induktif & $\begin{array}{l}\text { tidak } \\
\text { disebutkan }\end{array}$ & $\begin{array}{l}\text { tidak } \\
\text { disebutkan }\end{array}$ & $\begin{array}{l}\text { data dapat } \\
\text { dijelaskan }\end{array}$ & $\begin{array}{l}\text { belum } \\
\text { tepat }\end{array}$ \\
\hline 3 & 2005 & $\begin{array}{l}\text { Ekskavasi } \\
\text { Candi Agung } \\
\text { Tahun } 2005\end{array}$ & $\begin{array}{l}\text { dimana hunian; } \\
\text { dimana le tak } \\
\text { bangunan }\end{array}$ & $\begin{array}{l}\text { deskriptif- } \\
\text { eksplanatif }\end{array}$ & induktif & ekskavasi & $\begin{array}{l}\text { analisis } \\
\text { artefaktual }\end{array}$ & $\begin{array}{l}\text { permasalahan } \\
\text { belum } \\
\text { terjawab }\end{array}$ & $\begin{array}{l}\text { belum } \\
\text { tepat }\end{array}$ \\
\hline 4 & 2005 & $\begin{array}{l}\text { Penelitian } \\
\text { Sistem } \\
\text { Penguburan } \\
\text { Pada } \\
\text { Masyarakat } \\
\text { Dayak } \\
\text { Lawangan di } \\
\text { Barito Selatan }\end{array}$ & $\begin{array}{l}\text { a pa bentuk } \\
\text { data; } \\
\text { bagaimana } \\
\text { tatacaranya; } \\
\text { bagaimana } \\
\text { kesin ambungan } \\
\text { budayanya }\end{array}$ & $\begin{array}{l}\text { deskriptif- } \\
\text { eksplanatif }\end{array}$ & induktif & $\begin{array}{l}\text { survei- } \\
\text { wawancara }\end{array}$ & $\begin{array}{l}\text { identifikasi; } \\
\text { klasifika si; } \\
\text { kontekstual }\end{array}$ & $\begin{array}{l}\text { permasalahan } \\
\text { belum } \\
\text { terjawab }\end{array}$ & $\begin{array}{l}\text { belum } \\
\text { tepat }\end{array}$ \\
\hline 5 & 2006 & $\begin{array}{l}\text { Ekskavasi } \\
\text { Candi Agung } \\
\text { Tahun } 2006\end{array}$ & $\begin{array}{l}\text { dimana hunian; } \\
\text { dimana le tak } \\
\text { bangunan }\end{array}$ & $\begin{array}{l}\text { deskriptif- } \\
\text { eksplanatif }\end{array}$ & induktif & ekskavasi & $\begin{array}{l}\text { analisis } \\
\text { morfologi; } \\
\text { teknologi; } \\
\text { stilistik; } \\
\text { kontekstual }\end{array}$ & $\begin{array}{l}\text { permasalahan } \\
\text { belum } \\
\text { terjawab }\end{array}$ & $\begin{array}{l}\text { belum } \\
\text { tepat }\end{array}$ \\
\hline 6 & 2011 & $\begin{array}{l}\text { Penelitian } \\
\text { Arkeologi } \\
\text { Urban Bekas } \\
\text { Wilayah } \\
\text { Kerajaan } \\
\text { Paser di Kota } \\
\text { Tanah Grogot } \\
\text { Kabupaten } \\
\text { Paser, } \\
\text { Kalimantan } \\
\text { Timur }\end{array}$ & $\begin{array}{l}\text { bagaimana cirri } \\
\text { fisik dae rah } \\
\text { Tanah Grogot; } \\
\text { bagaimana } \\
\text { karakteristik } \\
\text { kehidupan } \\
\text { urban }\end{array}$ & eksplanatif & deduktif & $\begin{array}{l}\text { studi pustaka; } \\
\text { survei; } \\
\text { wawan cara }\end{array}$ & $\begin{array}{l}\text { analisis } \\
\text { kuantitatif; } \\
\text { kualitatif; } \\
\text { kontekstual; } \\
\text { geografi }\end{array}$ & $\begin{array}{l}\text { permasalahan } \\
\text { terjawab }\end{array}$ & tepat \\
\hline
\end{tabular}

